\title{
Maturation of ribbon synapses in hair cells is driven by thyroid hormone
}

\author{
PhD thesis
}

International Max Planck Research School

MSc/PhD Graduate Program in Neurosciences

Inner Ear Lab

University Hospital Göttingen

March 2007

Submitted by Gaston Sendin, born in Buenos Aires, April $13^{\text {th }} 1976$ 


\section{Declaration}

This thesis has been written independently and with no other sources and aids than quoted.

Gaston Sendin

March 2007 
To Carlos and Raquel

To all my friends in Europe and Argentina 
Zusammenfassung

In dieser Arbeit untersuchten wir die Organisation, molekulare Zusammensetzung und Funktion von Bändersynapsen innerer Haarzellen (IHC) in einem hypo-thyroiden Mausmodell $\left(\mathrm{Pax}-8^{-1}\right)$. In Messungen exozytotischer Kapazitätsveränderungen in IHCs hypo-thyroider Tiere fanden wir eine ineffiziente Kopplung zwischen Ca2+ Strom und Exozytose. Quantifizierung der Anzahl der Bändersynapsen durch Immunhistochemie und Konfokalmikroskopie offenbarte eine höhere Zahl an Synapsen in Pax- ${ }^{-/}$-Tieren im Vergleich zu Wildtyp- Tieren. Beide Eigenschaften weisen auf einen Verbleib hypo-thyroider IHCs in einem Entwicklungsstadium funktioneller und morphologischer Unreife hin. Durch Thyroxin-Ersatztherapie kann in diesen Zellen eine normale Entwicklung induziert werden.

Ebenso fanden wir in hypo-thyroiden Tieren weitere Anzeichen für eine unvollständige Entwicklung innerer Haarzellen, wie fehlende Expression von BKTyp K+ Kanälen, sowie verlängerte Präsenz der efferenten Innervation und der Aktionspotential-Generierung.

Auf der molekularen Ebene erforschten wir in hypo-thyroiden Mäusen die Expression von zwei präsynaptischen Proteinen (SNAP 25 und Synaptobrevin 1) und stellten Abnahmen der jeweiligen mRNA Konzentrationen fest.

Zusätzlich präsentiert unsere Studie ein Mausmodell zum Studium der auditorischen Funktion bei Menschen mit durch Thyroxin-Mangel hervorgerufener Taubheit. Wir schließen daraus, dass Thyroxin ein wichtiges Signal für die korrekte Entwicklung der inneren Haarzellen darstellt. 


\section{Abstract}

Ribbon synapses of inner hair cells (IHCs) undergo developmental maturation until after the onset of hearing. Here, we studied whether IHC synaptogenesis is regulated by thyroid hormone $(\mathrm{TH})$. We performed perforated patch-clamp recordings of $\mathrm{Ca}^{2+}$ currents and exocytic membrane capacitance changes in IHCs of athyroid and TH-substituted $\mathrm{Pax}^{-/-}$mice during postnatal development. $\mathrm{Ca}^{2+}$ currents remained elevated in athyroid IHCs at the end of the second postnatal week, when it had developmentally declined in wild-type and $\mathrm{TH}$ rescued mutant IHCs. The efficiency of $\mathrm{Ca}^{2+}$ influx in triggering exocytosis of the readily releasable vesicle pool was reduced in athyroid IHCs. Ribbon synapses were formed despite the TH-deficiency. However, different from wt, where synapse elimination takes place around the onset of hearing, the number of ribbon synapses remained elevated in 2-week-old athyroid IHCs. Moreover, the ultrastructure of these synapses appeared immature. Using quantitative RT-PCR we found a TH-dependent developmental upregulation of the mRNAs for the neuronal SNARE proteins SNAP25 and synaptobrevin 1 in the organ of Corti. These molecular changes probably contribute to the improvement of exocytosis efficiency in mature IHCs. IHCs of 2-week-old athyroid Pax8 ${ }^{-/-}$mice maintained the normally temporary efferent innervation. Moreover, they lacked large conductance $\mathrm{Ca}^{2+}$ activated $\mathrm{K}^{+}$channels and KCNQ4 channels. This together with the persistently increased $\mathrm{Ca}^{2+}$ influx permitted continued action potential generation. We conclude that $\mathrm{TH}$ regulates $\mathrm{IHC}$ differentiation and is essential for morphological and functional maturation of their ribbon synapses. 


\section{1-34 Introduction}

1 A general overview of hearing

8 The hair cells

13 The afferent synapse

24 Developmental changes in hair cells

29 Thyroid hormone action

33 The $\mathrm{Pax} 8^{-/-}$mouse

34-41 Materials \& Methods

34 Animals

35 Patch-clamp of IHCs

37 Immunocytochemistry

38 Confocal microscopy

38 Image analysis

39 Electron microscopy

39 Real-time RT-PCR

\section{1-59 Results}

41 Impaired maturation of presynaptic function in IHCs of athyroid mice 
46 IHCs ribbon synapses are morphologically immature in athyroid $\mathrm{Pax}^{-/-}$mice at $\mathrm{p} 15$

$49 \mathrm{TH}$ regulates the expression of genes encoding synaptic proteins in the organ of Corti

53 Lack of large conductance $\mathrm{Ca}^{2+}$-activated $\mathrm{K}^{+}$currents and $\mathrm{KCNQ}_{4}$ currents- Persistence of action potentials

58 Prolonged presence of efferent IHC synapses in $\mathrm{Pax}^{-/-}$mice

\section{9-68 Discussion}

61 Ribbon synapses are formed but their maturation is retarded in IHCs of athyroid mice

63 Towards deciphering the developmental improvement of stimulussecretion coupling in IHCs

65 Regulation of postnatal IHC development

\section{9-82 References}




\section{Introduction}

\section{A general overview of hearing}

Sound consists of propagating waves of compressions and rarefactions of the air. These waves can be produced by a wide variety of natural phenomena and also by highly specialized anatomical structures of some animals. Many of the Orthoptera (crickets, bushcrickets and grasshoppers) are known for their highly developed acoustic behaviour, a means of intraspecific communication. The species-specific sounds are produced by rubbing chitinous structures, the so called stridulatory organs. By modulating the frequency spectrum or temporal pattern in a particular way they convey meaning to these messages, which can then be decoded accordingly by conspecifics, subsequently activating a whole repertoire of behavioural programmes. Correct decoding is of the utmost importance, since in a given ecological niche it may become a matter of life or death.

Barn owls are nocturnal hunters of extraordinary auditory acuity and rely heavily on their internal representation of the auditory space to find their prey. By overlaying visual and acoustic maps of the surrounding space they are able to localize their target with an accuracy of $1^{\circ}$ in the horizontal plane (Hudspeth, 1997; Konishi, 2003).

Animals have developed many mechanisms for producing and emitting sounds for communication and the range of frequencies over which they can detect sound, changes from species to species. Whales and dolphins, for example, can detect frequencies in an extraordinary wide range, from $0.02 \mathrm{kHz}$ to $100 \mathrm{kHz}$ but crickets can do so only between $0.5 \mathrm{kHz}$ and $5 \mathrm{kHz}$ (Shepherd, 1994). Auditory function in 
mammals has a considerably increased limit of high-frequency hearing as compared with birds and other non-mammalian vertebrates. Audition in humans extends from about $0.02 \mathrm{kHz}$ to around $20 \mathrm{kHz}$ (Shepherd, 1994; Kros, 1996).

The sense of hearing in the vertebrates has an interesting phylogenetic history that is closely related to the development of the vestibular apparatus. Both senses are commonly regarded as adaptations of the lateral line organs present in all aquatic vertebrates, from primitive cyclostomes like the lamprey up through the amphibia. They consist of pits (ampullae) along the head or body of the animal. At the base of these pits, are clusters of cells called neuromasts, which are hair cells specialized for the detection of mechanical vibrations set up by movements of the fish through the water. These cells are sensory receptors used to transduce mechanical stimuli into electrical responses, signaling motion of the fluid around the animal (Shepherd, 1994).

Hair cells are retained as part of the Bauplan in higher vertebrates and when they are located in the auditory organ they also convert mechanical stimuli into electrical responses but in this case, the mechanical stimuli are caused by sound, endowing these animals with the ability to hear. They can also be located in the vestibular labyrinth mediating then our sensitivity to acceleration.

The organ of hearing in mammals, the ear, has three main parts (see Fig. 1). The outer ear aids in the collection of sound and funnels it through the external ear canal to the tympanic membrane, acting as an acoustic antenna. The middle ear contains 
a system of small ossicles, the malleus, the incus and the stapes, that conveys the vibrations of the tympanic membrane to the inner ear.

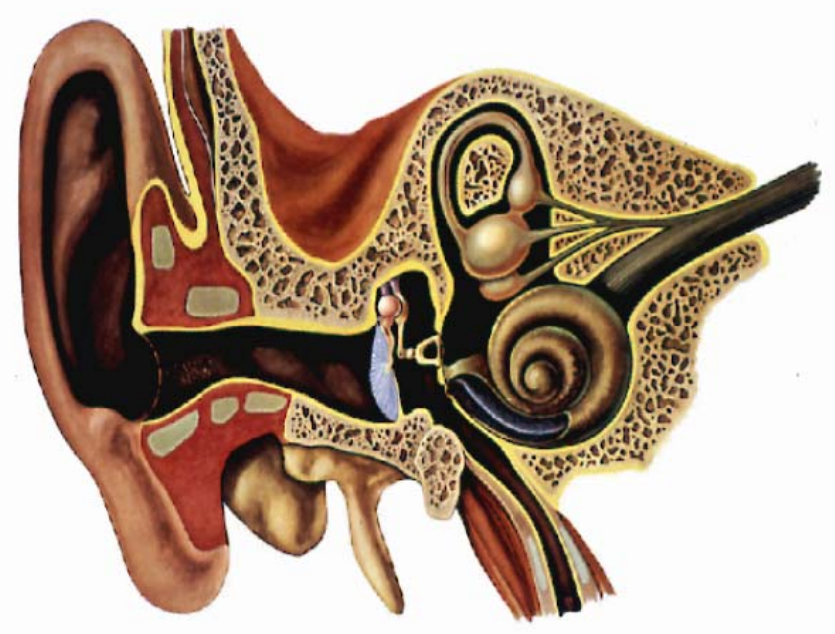

Fig. 1 The prominent auricle focuses sound into the ear canal. Alternating increases and decreases in air pressure vibrate the tympanum. These vibrations are conveyed across the air filled middle ear by the small ossicles. Vibrations of the stapes stimulate the cochlea, the hearing organ of the inner ear.

The efficient transmission of sound into the inner ear requires changing from sound waves propagating in air to vibrations of a fluid. This is achieved through the intermediary movements of the middle ear bones. Since air is highly compressible but fluids are not, the bones must provide for a matching of forces in the two media, a process called impedance matching. They do so by absorbing energy from the large area of the tympanic membrane and concentrating it in the small area of the stapes where it fits against an opening (the oval window) in the bone onto the membrane surrounding the cochlea. The surface ratio of eardrum to oval window (20/1) allows an adequate energy transfer of the sound pressure (Shepherd, 1994; Kandel et al., 2001). 
Nestled inside the inner ear is the cochlea, the snail-like organ that houses the sensory hair cells responsible for transducing sound waves into electrical impulses (Fig. 2).

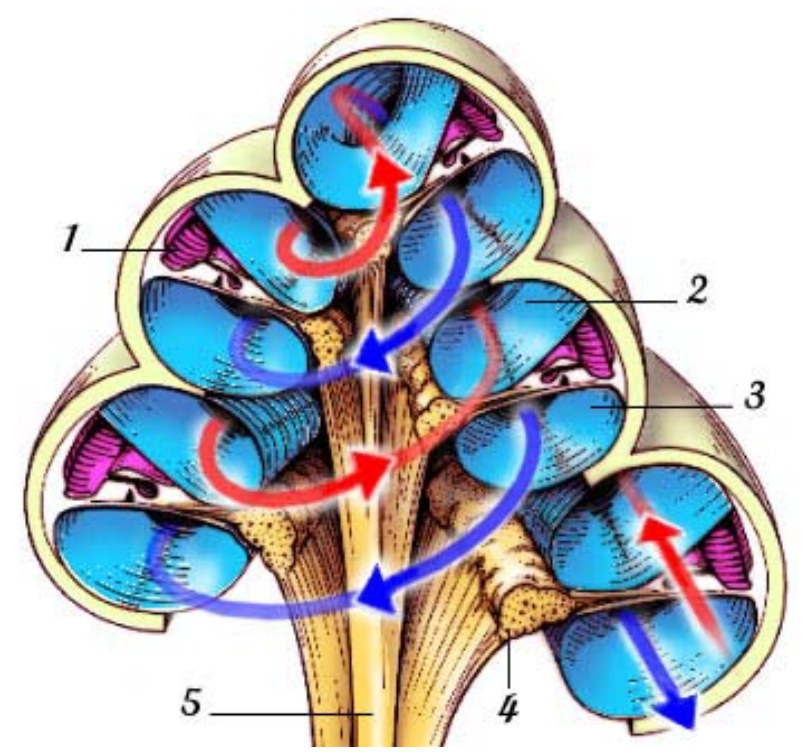

Fig. 2 Scheme of the cochlea. 1- Scala media 2- Scala vestibuli 3- Scala tympani 4- Spiral ganglion 5- Auditory fibers. Waves induced by sound move from the oval window in the scala vestibuli (direction of the red arrow) and proceed towards the round window in the scala tympani (direction of the blue arrow). Taken from www.iurc.montp.inserm.fr

The cochlea is partitioned into three compartments, namely scala vestibuli, scala media and scala tympani, whose internal milieux have different chemical compositions: perilymph (a solution rich in $\mathrm{Na}^{+}$and poor in $\mathrm{K}^{+}$) fills the scala vestibuli and the scala tympani while endolymph (a solution rich in $\mathrm{K}^{+}$and poor in $\mathrm{Na}^{+}$) bathes the hairlike stereocilia on the upper surface of the sensory cells.

On reaching the inner ear, sound waves deflect the stereocilia causing the transducer channels near their tips to open. The voltage gradient from the positive endocochlear potential to the negative potential inside the hair cell $(\sim+150 \mathrm{mV})$ drives 
inward $\mathrm{K}^{+}$flow, but must be continuously maintained by rapid recycling of $\mathrm{K}^{+}$back into the endolymph. At least six of the many proteins associated with deafness in humans and mice are directly involved in $\mathrm{K}^{+}$recycling (see Fig.3, taken from Steel, 1999).

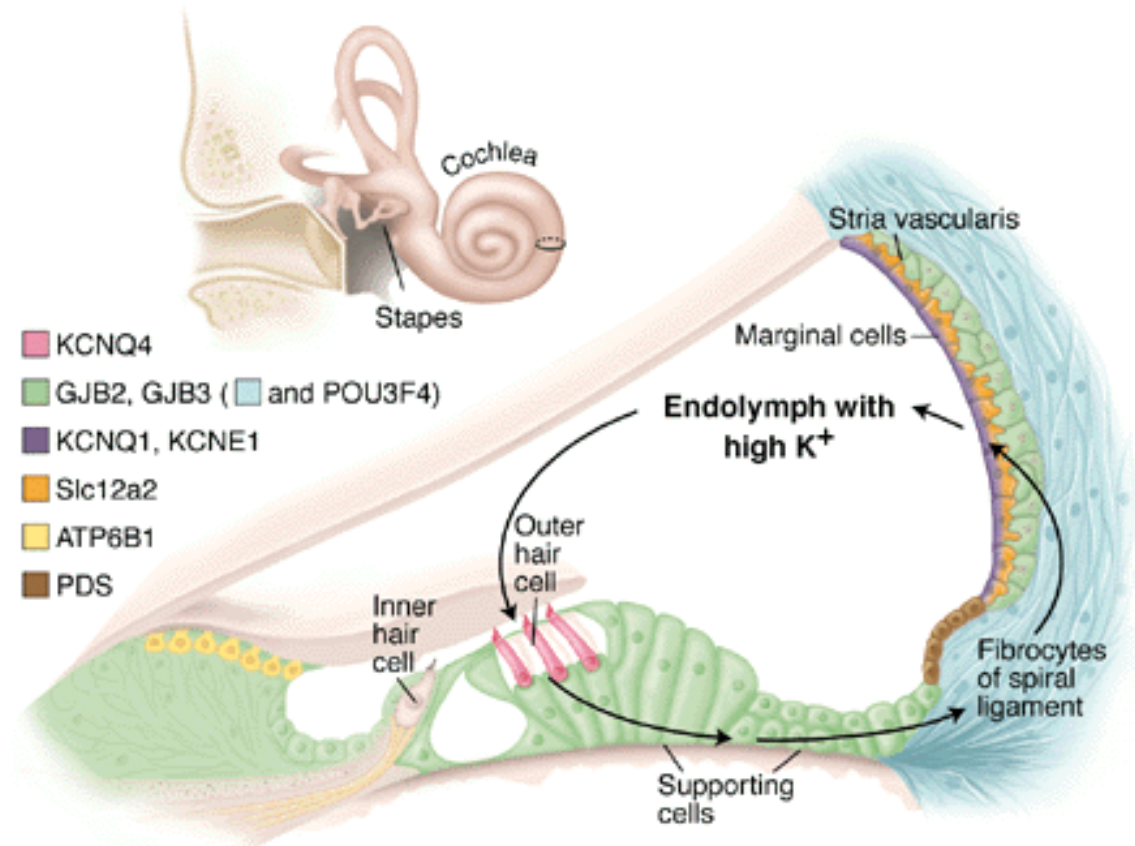

Fig. 3 The cochlea of the inner ear showing the location of key proteins involved in the recycling of $\mathrm{K}^{+}$back into the cochlear fluid (endolymph). The transcription factor POU3F4 is expressed in the fibrocyte cells of the spiral ligament (blue); KCNQ4 is expressed in the outer sensory hair cells (red); connexins 26 (GJB2) and 31 (GJB3) are expressed in the supporting cells, spiral ligament fibrocytes and in cells of the spiral limbus. $\mathrm{A} \mathrm{Na}^{+}-$ $\mathrm{K}^{+}-\mathrm{Cl}^{-}$cotransporter (Slc12a2) is expressed on the basolateral membrane of the marginal cells of stria vascularis (from Steel, 1999).

The organ of Corti is the neuro-sensory epithelium of the cochlea and contains two types of hair cells, the outer hair cells (OHCs) and inner hair cells (IHCs).

The outer hair cells (OHCs) are the most numerous type, with around 12000 cells in the human, arranged in three rows (see Fig. 4). Inner hair cells (IHCs) number about 3500 and are aligned in a single row. Around $90-95 \%$ of primary auditory neurons 
are connected to IHCs (type I) and only a small population of primary auditory neurons innervate OHCs (type II) (Kiang et al., 1982 \& see Figs. 5 \& 6).

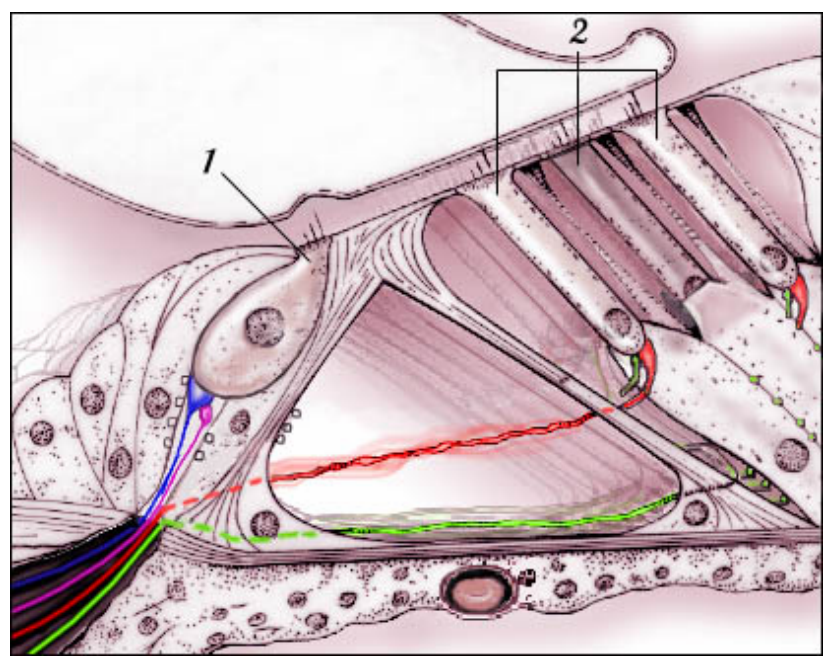

Fig.4 The afferents (blue) and the lateral efferents (pink) innervate the inner hair cells (1); the spiral afferents (green) and the medial efferents (red) innervate the outer hair cells (2). Taken from wWw. iurc.montp.inserm. fr

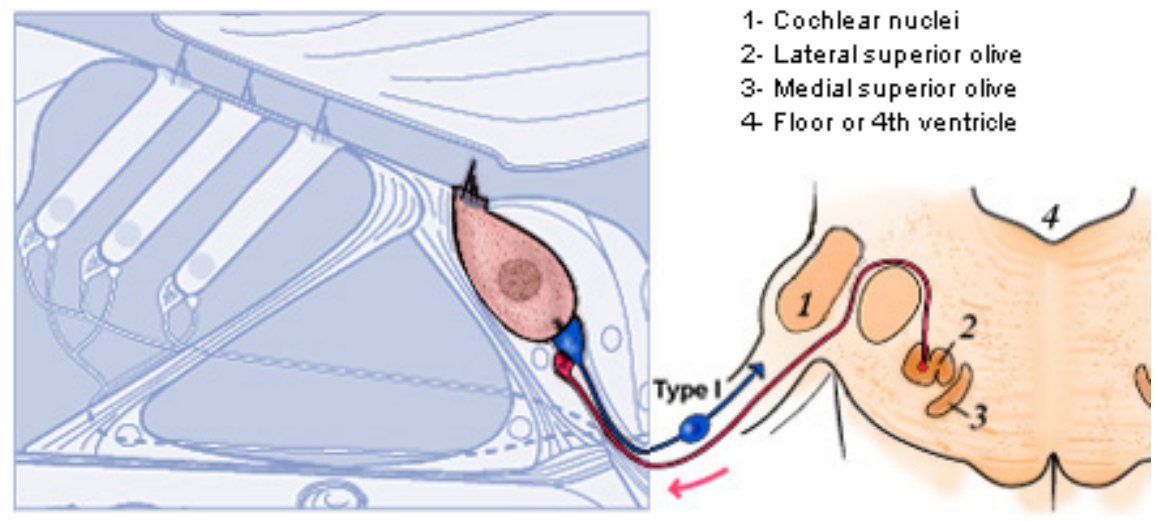

Fig.5 The IHCs make synapses onto the dendrites of type I spiral ganglion neurons forming the radial afferent system (blue) going to the cochlear nuclei (CN). The lateral system (pink) arising from small neurons in the ipsilateral lateral superior olivary complex (LSO) makes axodendritic synaptic contacts onto the IHC/type I afferent synapse. Taken from www. iurc.montp. inserm. fr 
The discovery of OHC's electromotility, e.g. changes in $\mathrm{OHC}$ length dependent on the voltage (Brownell et al., 1985) led to the concept of a "cochlear amplifier" involving active biomechanical input from the OHCs to the basilar membrane.

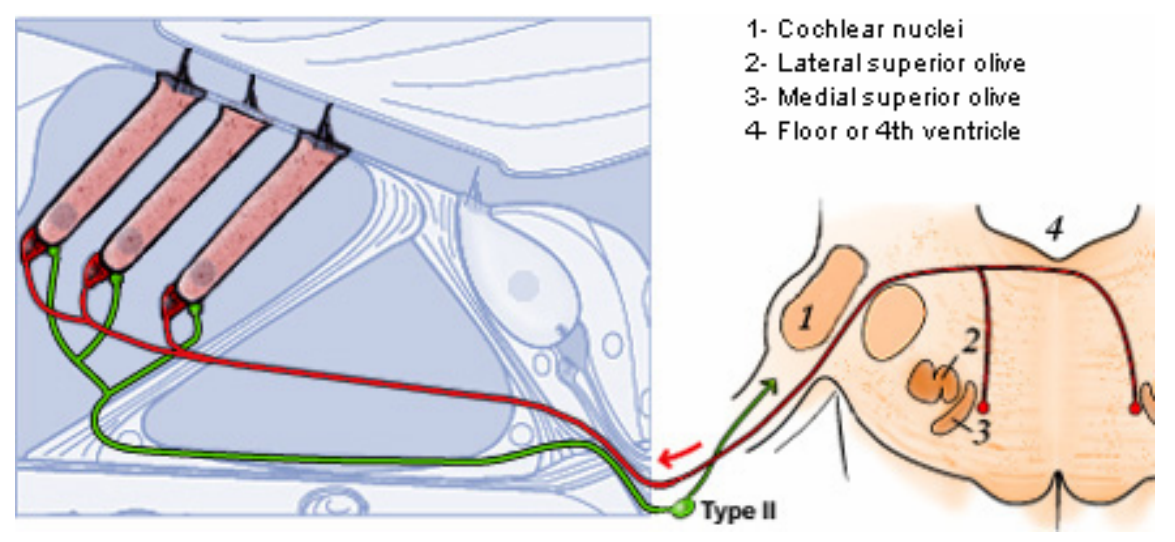

Fig.6 The OHC synapses with a few (at least in basal and mid-portions of the cochlea) small endings from type II spiral ganglion neurons, forming the spiral afferent system (green). In turn, large neurons of the medial efferent system (red), from both sides of the medial superior olivary complex (MSO), form axo-somatic synapses onto the OHCs. Taken from WWW.iurc.montp.inserm. fr

This input improves low-level sensitivity almost 100 -fold (i.e. $40 \mathrm{~dB}$ ) and sharpness of tuning by enhancing the vibration of a narrow region of the cochlea, acting against the dampening produced by viscous forces (Ashmore, 2002). This assumption is further substantiated by the cochlea's ability to produce acoustic energy which can be recorded by placing a microphone in the ear canal. These responses are called otoacoustic emissions and are absent when OHCs are damaged (Puel, 1995).

The mammalian cochlea is a spectral analyser of the frequencies present in complex sounds and it does this by using the mechanical properties of the cochlear partition. As explored by von Békésy in the 1940s, the stiffness gradient along the partition sets up a logarithmic frequency map so that differing frequencies are associated with 
different resonant excitation sites. As a result of this, the propagating wave has its largest amplitude at a specific site along the basilar membrane, depending on the frequency. The peaks corresponding to high frequencies generally occur towards the base while low frequencies are represented near the apex.

At each site along the cochlea, the basilar membrane motion is signalled to the auditory nerve by the inner hair cells. The primary cellular event is the deflection of the hair bundle. Such deflections occur at the same rate as the sound frequency and hence a primary requirement is that the mechano-electrical transduction step is rapid. TRPA1, a member of the TRP channel family, has been initially postulated as the molecular entity mediating this step but recently a mouse line where this gene had been knocked-out showed no hearing impairment (Corey et al., 2004; Bautista et al., 2006). In nematodes, members of the DEG/ENaC channel family have been shown to mediate mechanosensation and loss of mechanosensitivity has been associated with mutations in the nompC gene in Drosophila (reviewed in Gillespie \& Walker, 2001; O'Hagan et al., 2005) but so far no homologue of these channels has been directly linked to this function in mammals.

\section{The hair cells}

Hair cells are polarized epithelial cells whose major functions are partitioned into apical and basolateral compartments. The apical end harbors the cellular machinery responsible for the reception and translation of mechanical energy into electrical energy (mechanoelectrical transduction, MET), whereas the basolateral region is 
specialized for the transmission of information to the central nervous system via synaptic contacts with the primary afferent neurons.

The hair bundle, the organelle where mechanotransduction takes place, protrudes from the apical surface and consists of tens to hundreds of stereocilia, depending on the species, that are graded in height from one edge of the bundle to the other (Fig.7).
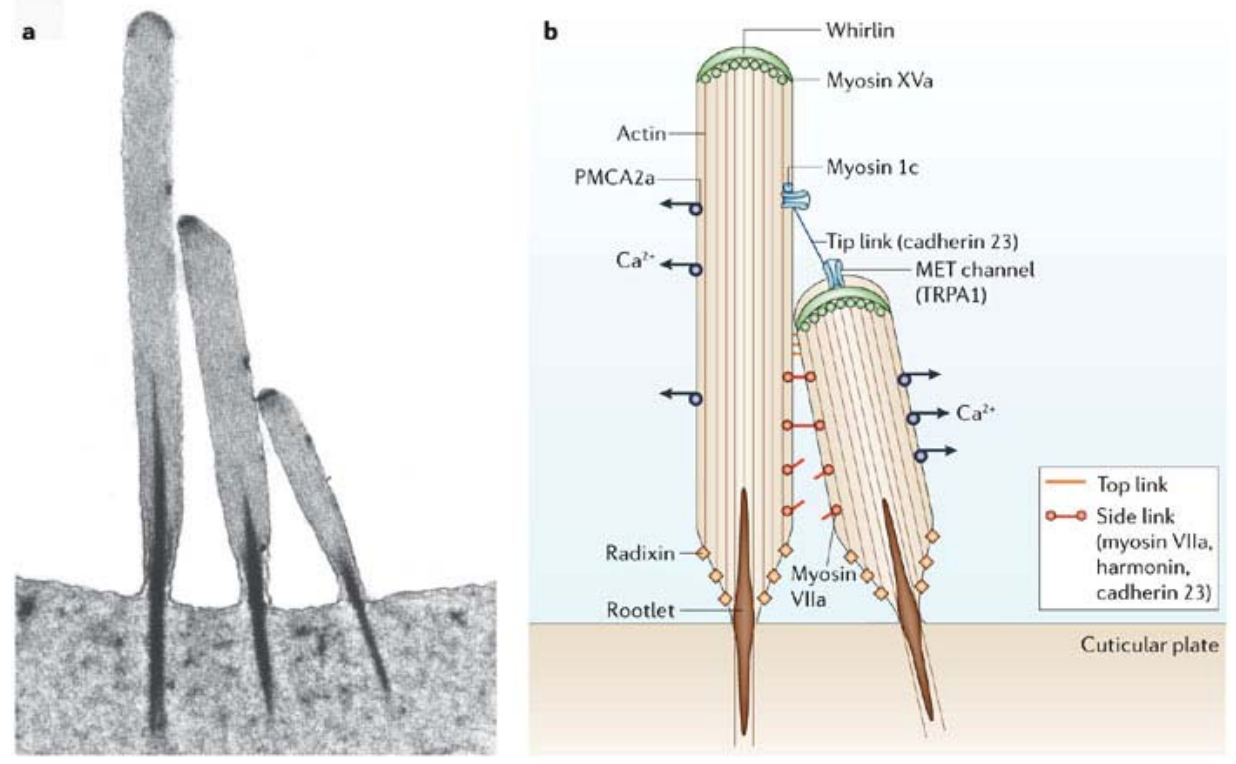

Fig. 7 (Left) Transmission electron microscopy through the three rows of stereocilia on a guinea pig outer hair cell. The hair bundle of a mammalian OHC contains 30 to 100 stereocilia. (Right) Putative locations of some of the protein constituents of the stereocilia. Some, like myosin 1c were first identified in vestibular hair cells and their location has not been confirmed in cochlear hair cells. MET, mechanotransducer channel, PMCA2a, plasma membrane CaATPase pump, TRPA1, transient receptor potential channel A1 (taken from Fettiplace \& Hackney, 2006).

Stereocilia are packed with actin fibres that span their length from tip to base, and are crosslinked with espin and fimbrin. Whirlin and a non-muscle myosin, myosin XVa probably team up to resupply the actin polymers at the tip with newly added monomers which, over the course of 2 days, will dissociate at the base in a dynamic 
process called treadmilling (Schneider et al., 2002; Belyantseva et al., 2005). Mature stereocilia are connected by side links that probably involve a scaffolding unit comprised of several types of proteins: cadherins, PDZ-containing proteins like harmonin and myosin VIla. Apart from the side links, stereocilia also are held together by the tip links, which extend from the vertex of each stereocilium to the side of its taller neighbour (Kachar et al., 2000). They are oriented to apply force during deflection of the bundle towards its tallest member, and to unload with deflection towards its shortest edge (reviewed in Fettiplace \& Hackney, 2006). Two lines of evidence implicate them in the transmission of force to MET channels due to hair bundle deformation. First, application of submicromolar $\mathrm{Ca}^{2+}$ buffered with BAPTA to the hair bundle destroys the tip-links and abolishes transduction (reviewed in Fettiplace \& Hackney, 2006). Second, by loading the hair cells with a $\mathrm{Ca}^{2+}$ sensitive dye to image $\mathrm{Ca}^{2+}$ influx through open channels, it was shown that MET channels are located at the tips of stereocilia, close to the tip-link insertion point (Denk et al., 1995). Recent work suggested that cadherin 23 could be a component of the tip link (Siemens et al., 2004; Söllner et al., 2004).

The MET channel is most selective for $\mathrm{Ca}^{2+}$ but shows appreciable permeability to small monovalent cations. In response to a step hair bundle deflection it opens in about $100 \mu$ s and then recloses in two phases of adaptation. The first phase occurs within 1-2 ms (known as fast adaptation) and the second one can take tens or hundreds of milliseconds (slow adaptation).

Stereociliary $\mathrm{Ca}^{2+}$ is crucial for MET channel performance. $\mathrm{Ca}^{2+}$ entering through these channels can be buffered by proteins like parvalbumin $\beta$ (Hackney et al., 
2005) and leave the stereocilia through the PMCA2a isoform of a Ca-ATPase pump (reviewed in Fettiplace \& Hackney, 2006).

Increases of $\mathrm{Ca}^{2+}$ in the stereocilia speed up the rate of activation and both fast and slow components of adaptation of the MET channel. The rate of fast adaptation is inversely related with the characteristic frequency of the hair cell, that is, hair cells tuned to higher frequencies have smaller time constants for fast adaptation. In the turtle hair cells and rat OHCs this is achieved by systematically varying the unitary conductance of the MET channel along the cochlea, allowing for larger increases of $\mathrm{Ca}^{2+}$ influx, thus speeding up fast adaptation kinetics (Ricci et al., 2003, 2005). Fast adaptation is probably caused by incoming $\mathrm{Ca}^{2+}$ which reduces the open probability of the MET channel during a positive deflection of the hair bundle, and perhaps involves direct binding of the ion to the channel (Fig.8, reviewed in LeMasurier \& Gillespie, 2005).

The slow component probably takes place when a motor protein, most likely myosin 1c (Holt et al., 2002), slides down the stereocilium allowing channels to close. However this experiment was performed on vestibular hair cells, so evidence along this direction is still missing in cochlear hair cells. After the bundle is returned to rest, gating-spring tension is very low; adaptation re-establishes tension and returns the channel to the resting state (Fig.8, reviewed in LeMasurier \& Gillespie, 2005). 


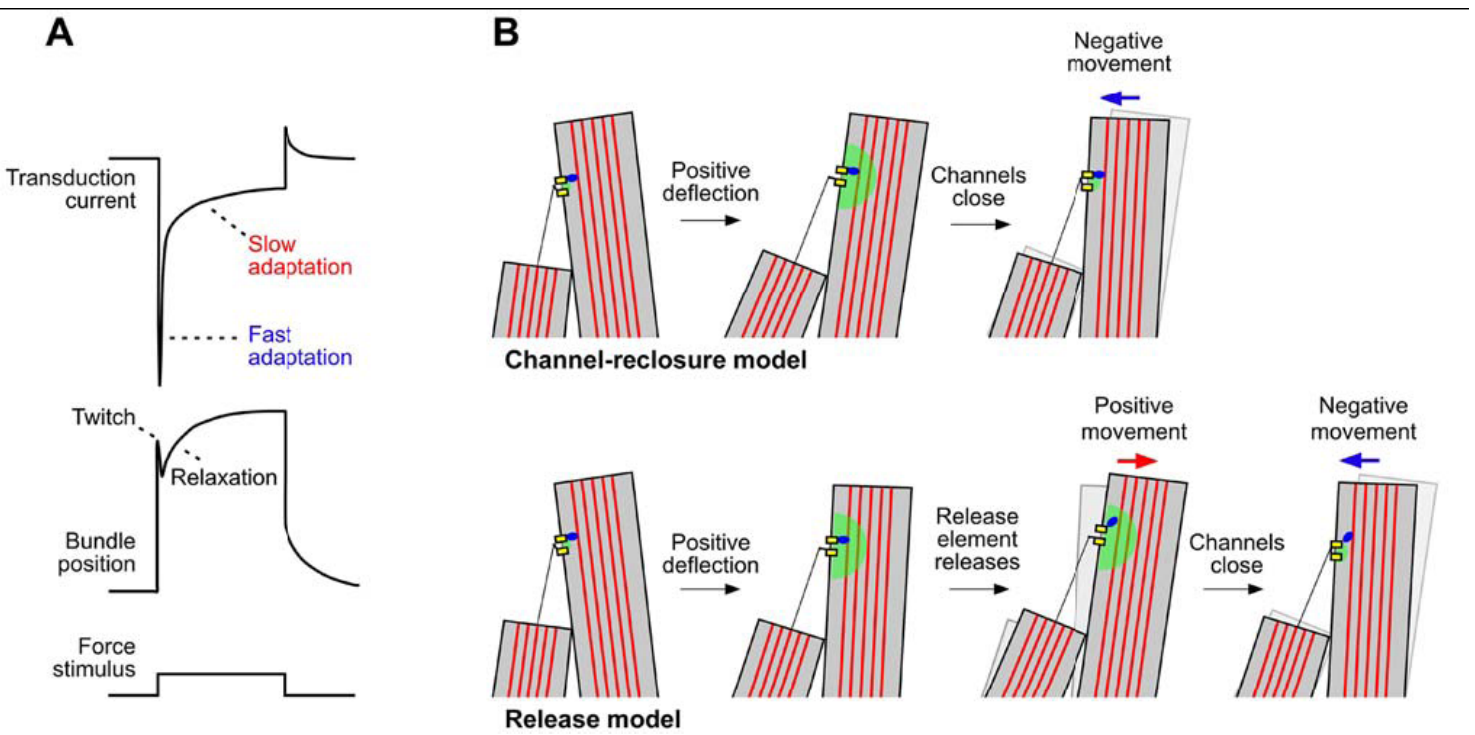

Fig.8 (A) Simulated transduction current and mechanical behaviour in response to a force stimulus. Fast and slow adaptation are respectively associated with the rapid, negative-going bundle "twitch" and the slow positive relaxation. (B) Models for fast adaptation. Top: channel reclosure model. A positive deflection opens channels and lets in $\mathrm{K}^{+}$and $\mathrm{Ca}^{2+} ; \mathrm{Ca}^{2+}$ binds to a site on the MET channel and stimulates its closure. Bottom: Release model. $\mathrm{Ca}^{2+}$ binds to a site on the release element, which rapidly elongates and reduces tension in the gating spring, allowing the bundle to relax forward. Subsequent channel closure increases gatingspring tension, resulting in negative movement of the bundle to relieve the tension (From LeMasurier \& Gillespie, 2005).

The prevailing view states that mechanical amplification in mammals stems from the somatic motility of OHCs, which manifests itself as voltage-dependent changes in the length of OHCs imparted by the conformational changes of prestin, a transmembrane protein with piezoelectric properties (Zheng et al., 2000). Targeted deletion of prestin leads to absence of electromotility in isolated OHCs in vitro as well as lack of normal cochlear amplification in vivo (Liberman et al., 2002). The intracellular anions $\mathrm{Cl}^{-}$and $\mathrm{HCO}^{3-}$ probably act as the voltage sensor of prestin, translocating across the membrane in response to changes in the transmembrane voltage and hence triggering conformational changes of the protein (Oliver et al., 2001). However, it is not clear whether somatic motility, whose frequency range may be limited by the membrane time-constant $\left(f_{c} \sim 1 \mathrm{kHz}\right)$, could cover the entire 
operating bandwidth in mammals. In non-mammals substantial force can be generated by fast adaptation of the MET channels (Ricci et al., 2002) and it was recently postulated that this mechanism could also endow mammalian OHCs with the ability to transduce at high frequencies (Chan \& Hudspeth, 2005; Kennedy et al., 2005; Kennedy et al., 2006).

\section{The afferent synapse}

Different from CNS synapses, where neurotransmitter release is driven by stereotyped action potentials, the mature inner hair cell relies on graded receptor potentials to release synaptic vesicles. Sound intensity is presynaptically encoded by changing the amplitude of the receptor potential but afterwards these electrical responses to sound must be faithfully translated into a neural spike code in the postsynaptic neuron and hence it becomes crucial to study the transfer characteristics of the hair cell's afferent synapse in order to understand this process.

The ability of auditory synapses to preserve temporal information is remarkable. For example, the circuit in the barn owl responsible for sound localization can resolve $\mu \mathrm{s}$ differences in the arrival times of sound to each ear (Hudspeth, 1997). The firing of an auditory fiber can follow the periodicity of tonal stimuli up to a few $\mathrm{kHz}$, a property called phase-locking, and probably neurotransmitter release must also comply with this timing. Even in the absence of stimulation, the hair cell afferent synapse drives the spiral ganglion neuron at rates exceeding $100 \mathrm{~Hz}$ (reviewed in Moser et al., 2006a). 
Recording of the IHC receptor potentials with sharp electrodes revealed a large AC component for sound frequencies below about $2 \mathrm{kHz}$; above this frequency, the DC component predominates (Palmer \& Russell, 1986). Intracellular recordings from giant afferent fibers of the goldfish sacculus revealed that EPSPs show high temporal resolution and that hair cell receptor potentials do not adapt to successive sinusoidal displacements of hair cell bundles but transmitter release from the afferent synapse does. Surprisingly, adaptive rundown of EPSPs occurred at the same rate regardless of the stimulus intensity (Furukawa \& Matsuura, 1978; reviewed in Fuchs, 2005).

How do auditory nerve fibers code a wide dynamic range of sound intensities within the more limited scope of a neural spike-rate code? The answer appears to be range fractionation. Measurements of auditory nerve fibers in guinea pigs led Winter et al. (1990) to divide the fibers in three categories: high spontaneous rate-low threshold fibers, low spontaneous rate-high threshold fibers and a third group of fibers with intermediate properties. Interestingly, high spontaneous rate fibers seem to be more abundant on the pillar side of IHCs in the cat, compared with the modiolar side, where low spontaneous rate fibers are located (Liberman, 1982). The presynaptic and postsynaptic specializations that underlie presumably different synaptic transfer functions at these fibers are currently unknown.

Thus, it could prove useful to consider first the performance of the hair cell afferent synapse in the context of various types of contacts found in the CNS. 
At conventional neuron-neuron synapses, multiple active zones participate in transmission, each releasing one or two vesicles, but rarely more, in response to a single presynaptic action potential (Forti et al., 1997; Ryan et al., 1997; Trussell, 2002). In this case, an action potential will trigger the release of either one vesicle or none, and there will be quite unreliable and poor timing of the resulting evoked EPSC (Fig. 9B).

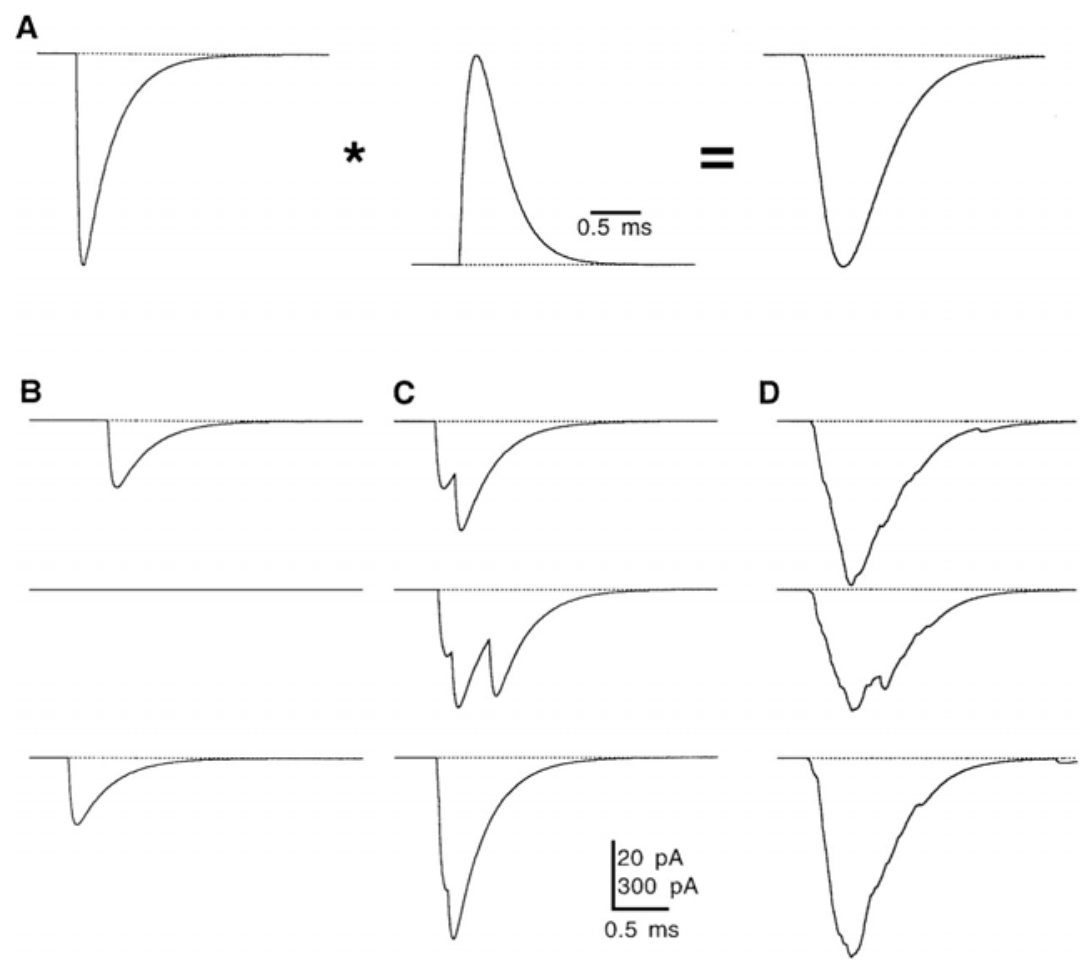

Fig.9 Effect of number of release sites on excitatory postsynaptic current (EPSC) variability. (A) At synapses where the contribution of each released vesicle to the EPSC is independent, the EPSC (right) is given by the convolution of the probability of release time course (middle) and the miniature (m) EPSC (left). In this example, the mEPSC has a time constant of decay of $300 \mu \mathrm{s}$, and the probability of release has an integrated release probability of 0.28 per site. EPSCs were calculated by convolving a mEPSC with the summed, randomly generated release distributions of (B) 1 , (C) 5 or (D) 200 release sites each with the profiles depicted in (A). The vertical scale in $D$ is 15 times the vertical scales of $B$ and $C$. Taken from Sabatini \& Regehr, 1999. 
Other synapses are comprised of a number of release sites so that few vesicles will fuse following an action potential, and consequently there will be variability in the number of mEPSCs contributing to the EPSC and in the timing of the EPSC (as shown in Fig. 9C). Still other connections involving hundreds of release sites will originate highly timed and stereotyped EPSCs (Fig. 9D). Large suprathreshold synaptic inputs with little amplitude variability will be therefore more effective at preserving timing information (Sabatini \& Regehr, 1999).

The latter synaptic arrangement holds true for an auditory synapse, the calyx of Held in the brainstem, where tight control of the postsynapse is achieved by around 600 release sites, each with a low probability of release.

In contrast to this synapse, the afferent synapse of the mammalian IHC uses a single active zone holding a large pool of vesicles to accomplish the same task, ensuring equally reliable and temporally precise transmission. Each depolarization, the signal to release transmitter, is very brief during high-frequency sounds, hence narrowing the time window over which vesicle release can occur. If the $\mathrm{IHC}$ would rely on the release of a single vesicle, any reduction in vesicle availability would simply stop transmission. A large vesicle pool at these synapses warrants sustained transmission during ongoing sound stimuli (Trussell, 2002).

In CNS synapses the postsynaptic response to a quantum released in response to a presynaptic AP is small and summation of small events is required to reach the threshold for firing. In hair cells, however, it seems that most postsynaptic signals generated even by spontaneous exocytosis from hair cells are suprathreshold and produce spikes (Siegel, 1992). 
What are the specializations that ensure such performance? Mature afferent hair cell synapses usually display one single presynaptic electron dense body, an osmiophilic structure called ribbon (Fig. 10).
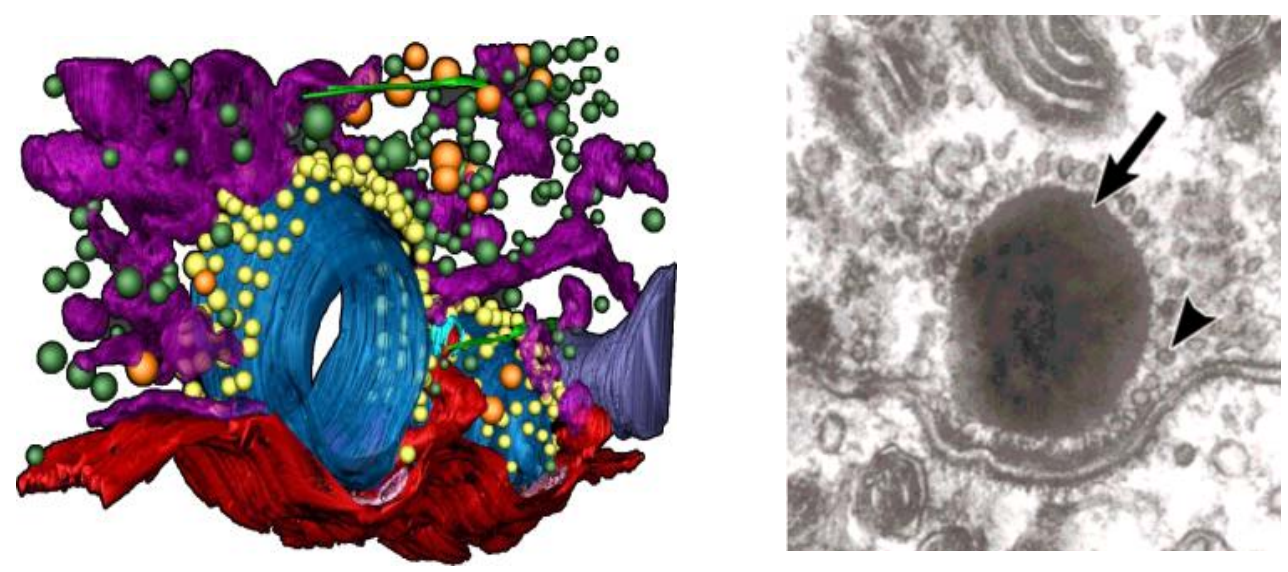

Fig. 10 (Left) 3D rendering of a frog saccular hair cell synapse partially reconstructed by electron tomography (Lenzi et al., 2001). Approximately $2 / 3$ of a spherical ribbon, shown as a hollow object (blue) was captured in the reconstruction. Ribbon tethered vesicles are yellow and include those docked beneath the ribbon. Other vesicles are green, while membraneous tubules and cisternae are purple. (Right) Transmission electron micrographs of a frog inner ear hair cell ribbon synapse. The ribbon (arrow) is surrounded by a halo of synaptic vesicles (arrowheads, taken from Lenzi \& von Gersdorff, 2001).

Ribbons also distinguish the presynaptic active zones of photoreceptors and bipolar cells in the retina, as well as the pinealocytes of the pineal gland. In fish and amphibians, they are also present at the electroreceptors of the lateral line. Ribbons can assume different shapes and sizes in different cell types and species and their number can vary according to stages of development and the tonotopic position along the cochlea (Sobkowicz et al., 1982; Lenzi \& Von Gersdorff, 2001; Schnee et al., 2005; reviewed in Moser et al., 2006). They are generally covered by a monolayer of synaptic vesicles, some of which also dock to the presynaptic membrane. Other vesicles are docked to the presynaptic membrane but not 
anchored to the ribbon and finally a third group comprises vesicles present in the cytosol in the vicinity of the ribbon (see Fig. 10).

The molecular constituents of ribbons are beginning to emerge. Some of these features are shared among retinal and hair cell ribbons but others are cell-type specific. For instance, both retinal and hair cell ribbons contain RIBEYE, Bassoon and Piccolo. Deletion of a major part of the Bassoon gene results in the release of the ribbons from their anchoring sites. Moreover a fast component of exocytosis is greatly reduced and both synchronous afferent synaptic transmission and hearing are impaired (Khimich et al., 2005).

Hair cells express the SNARE proteins syntaxin 1, SNAP-25 and synaptobrevin 1 but, like photoreceptors, lack synapsins. Synaptotagmin 1 and 2, believed to be the calcium sensors for fusion at central synapses are absent in hair cells (Saffiedine \& Wenthold, 1999). Recently otoferlin, a C2-domain containing protein, has been implicated in a late step in the fusion of synaptic vesicles at the hair cells synapse (Roux et al., 2006). Different from other synapses, neurotransmitter release in hair cells is controlled by $\mathrm{Ca}_{v} 1.3$ L-type $\mathrm{Ca}^{2+}$ channels (Platzer et al., 2000; Brandt et al., 2003; Brandt et al., 2005). $\mathrm{Ca}^{2+}$ channels cluster at active zones in both hair cells and bipolar cells, as shown by different techniques (Zenisek et al., 2003; Brandt et al., 2005).

At least two kinetic components of release have been identified in bipolar cells and hair cells (Von Gersdorff \& Matthews, 1994; Moser \& Beutner, 2000; Spassova et al., 2004). The first kinetic component mediates exocytosis at very high rates but exhausts after a few milliseconds (depletion time constant=9 ms in IHCs from 8- 
week mice, 53-64 vesicles/ribbon, data at $10 \mathrm{mM}$ extracellular $\mathrm{Ca}^{2+}$, Khimich et al., 2005). Because it is the fastest discernible and saturable component, several authors named it readily releasable pool (RRP). Exogenous slow buffer leaves this component untouched, a hint of the colocalization of this pool with $\mathrm{Ca}^{2+}$ channels (Moser \& Beutner, 2000; Spassova et al., 2004). RRP size correlates with the number of afferent synapses made by a hair cell along the tonotopic axis of the cochlea (Schnee et al., 2005), the number of synapse-anchored ribbons (Khimich et al., 2005) and the amplitude of the compound action potential of the spiral ganglion, which reflects synchronous activation of spiral ganglion neurons (Khimich et al., 2005). All these observations implicate the RRP in highly synchronous soundcoding.

The exhaustion of this fast component of exocytosis has been hypothesized to underlie a form of neural adaptation (Moser \& Beutner, 2000); following this reasoning, recovery from adaptation would imply rapid refilling of this pool with synaptic vesicles. Recently it was shown in the chick, that the kinetics of soundevoked nerve activity adaptation and recovery from adaptation mirrored the time course of RRP depletion and replenishment (Spassova et al., 2004).

The extremely high initial release-rate of the RRP obtained by capacitance measurements in the mouse hair cell ( $\sim 6000$ vesicles/s, using a 28 aF conversion factor for the capacitance of a single synaptic vesicle, Moser \& Beutner, 2000) was comparable to the value obtained for the fastest release component in guinea pig hair cells (3000 vesicles/s, using 2-photon imaging of FM1-43 stained vesicles, Griesinger et al., 2005). The assignment of anatomical pools of vesicles to this 
functionally identified kinetic component of release remains controversial: some authors postulate that the readily releasable vesicles may be those that are docked at the plasma membrane of the active zone (Moser \& Beutner, 2000; Khimich et al., 2005; Schnee et al., 2005; Rutherford \& Roberts, 2006) or alternatively that all the vesicles tethered to the ribbon comprise this fast pool (Edmonds et al., 2004; Spassova et al., 2004). The first component of release entailed docked vesicles in a study done with evanescent wave microscopy in retinal bipolar nerve terminals (Zenisek et al., 2000), however 2-photon imaging of FM1-43 stained vesicles in guinea pig hair cells showed that rapid exocytosis of non-docked vesicles could occur (Griesinger et al., 2005).

Our present understanding of the slower component of release, which takes place during prolonged depolarization (from tens of ms to $1 \mathrm{~s}$ ), is very limited (reviewed in Nouvian et al., 2006). This slower component is believed to represent the resupply of readily releasable vesicles to the active zone and their subsequent exocytosis or the release of vesicles from a secondary pool that is located further away from the $\mathrm{Ca}^{2+}$ channels (von Gersdorff et al., 1996). In any case, it is clear that hair cells are capable of huge membrane turnover as shown also by flash photolysis experiments (Beutner et al., 2001). The ribbons would then probably stabilize a large pool of vesicles (100-200 vesicles associated to the ribbon and 16-30 docked vesicles per active zone, mouse IHC, Khimich et al., 2005) that could support indefatigable release during prolonged acoustic stimulation. Contrary to central synapses, where a significant period of time is needed for recovery after stimulation, hair cells seem to 
be endowed with a large back-up of vesicles that allow for fast replenishment of this pool ( $70 \%$ of the fast pool recovered with $\tau=140 \mathrm{~ms}$, Moser \& Beutner, 2000).

Postsynaptic recordings from the tiny afferent boutons of spiral ganglion neurons in young rats have revealed that the AMPA subtype of glutamate receptor with rapid kinetics mediates each EPSP (Glowatzki \& Fuchs, 2002). Moreover, each synaptic ribbon could indeed release multiple vesicles at once, in a highly synchronized fashion. These recordings had large quantal variability (CVs between $77-95 \%$ ) and their amplitude distribution was highly skewed. The average EPSC was estimated to be contributed by 3-6 vesicles and the largest EPSC recorded was probably comprised of 22 vesicles (Glowatzki \& Fuchs, 2002).

Paired recordings of presynaptic $\mathrm{Ca}^{2+}$ currents and EPSCs in the bullfrog amphibian papilla also showed broad distributions of EPSCs indicative of multivesicular release. In addition, the relation between presynaptic $\mathrm{Ca}^{2+}$ current and postsynaptic current appeared to be linear (Keen \& Hudspeth, 2006). Such a relationship has also been observed for another synapse operating with graded potentials, the rod photoreceptor's synapse, at which the linearity between presynaptic $\mathrm{Ca}^{2+}$ signals and vesicle fusion probably facilitates the encoding of small changes in illumination (Thoreson et al., 2004). Vesicle exocytosis in excitable cells typically has a highorder dependence on presynaptic $\mathrm{Ca}^{2+}$ entry (Dodge \& Rahamimoff, 1967). However, in the mouse cochlea this seems to apply only to immature IHCs in which the relationship between $\mathrm{I}_{\mathrm{Ca}}$ and $\Delta \mathrm{C}_{\mathrm{m}}$ was approximated by a power of four, while a nearly linear dependence characterized adult IHCs (Johnson et al., 2005). A uniform step increase in the cytosolic $\mathrm{Ca}^{2+}$ concentration by flash photolysis of caged $\mathrm{Ca}^{2+}$, 
which triggers the exocytosis of all fusion-competent vesicles, revealed an intrinsic cooperativity in the fusion process of around $5 \mathrm{Ca}^{2+}$ ions per release event (Beutner et al., 2001). What causes the mature apparent cooperativity to linearize, e.g. to deviate from the intrinsic cooperativity of the fusion reaction? Evidence indicates that, contrary to models where release of a synaptic vesicle is controlled by overlapping calcium domains of several $\mathrm{Ca}^{2+}$ channels, the release of a single vesicle could be regulated by one or few $\mathrm{Ca}^{2+}$ channel at the mouse hair cell ribbon synapse. Brandt et al. (2005) estimated that around 80 channels sit at the synapse of which about 20 would be simultaneously open. They also found that manipulations of the number of open channels yielded a more linear relationship between $\mathrm{I}_{\mathrm{Ca}}$ and exocytosis of the RRP while changes of the apparent $\mathrm{Ca}^{2+}$ domain by reducing or augmenting extracellular $\mathrm{Ca}^{2+}$ produced a supralinear dependence with an apparent cooperativity of $\sim 4$. Similarly, depolarizations to more positive potentials elicited more exocytosis of the RRP than depolarizations to more negative potentials, despite very similar whole-cell $I_{\mathrm{Ca}}$ in both cases. Such a "nanodomain" control of vesicle release would timely signal acoustic information to the postsynapse even at low stimulus intensities, without recruitment of many channels (Brandt et al., 2005).

To perform such diverse functions like transduction, tuning and neurotransmission, a compact cell like the hair cell needs to spatially constrain $\mathrm{Ca}^{2+}$ signaling. How can such a diversity of tasks requiring different $\mathrm{Ca}^{2+}$ signals be accomplished? One strategy would be to spatially restrict the signals by means of generating an 
intricate geometry with protrusion of spines, like the Purkinje cells of the cerebellum. Hair cells, however are compact epithelial cells, and thus rely on the $\mathrm{Ca}^{2+}$ buffering proteins to confine the $\mathrm{Ca}^{2+}$ signal to the relevant compartments.

Three of the major $\mathrm{Ca}^{2+}$ buffering proteins are calretinin, calbindin and parvalbumin. Calretinin contains $5 \mathrm{EF}$ domains that bind $\mathrm{Ca}^{2+}$, having a $\mathrm{k}_{\text {on }}$ comparable to BAPTA, a reason why it is generally considered as a fast buffer.

Calbindin has 4 EF domains of different affinities, with the $k_{o n}$ of the low affinity site approaching BAPTA and the $k_{\text {on }}$ of the high affinity site resembling EGTA. This mixture of different kinetics make this protein be overall slower than calretinin. Finally, parvalbumin $\alpha$ has $3 \mathrm{EF}$ domains with $\mathrm{Ca}^{2+} / \mathrm{Mg}^{2+}$ selectivity and a $\mathrm{k}_{\text {on }}$ very similar to EGTA, a reason why it is widely regarded as a slow buffer. Another member of the parvalbumin family is parvalbumin $\beta$, also known as oncomodulin. This protein does not have any $\mathrm{Ca}^{2+} / \mathrm{Mg}^{2+}$ antagonism and is faster than parvalbumin $\alpha$ (Schwaller et al., 1997; Nägerl et al., 2000).

Using immunohistochemistry, it was shown that calbindin stains OHCs and IHCs in a decreasing gradient from apex to base in the guinea pig and gerbil, without labeling stereocilia, supporting cells and fibers. Parvalbumin staining was present only in $\mathrm{IHCs}$ and displayed the same longitudinal gradient. Calretinin stained only IHCs and Deiters cells (Slepecky \& Ulfendahl, 1993; Pack \& Slepecky, 1995).

How abundant are these buffers in hair cells? The first estimates of the concentration of these proteins in hair cells were done by resolving the proteins 
present in frog saccular hair cells on polyacrylamide gels and conducting quantitative Western blots with protein standards. Based on this approach, the authors concluded that the cytosolic concentration of parvalbumin 3 (probably, a non-mammalian ortholog of oncomodulin) was around $3 \mathrm{mM}$ in hair cells of the bullfrog (Heller et al., 2002). Using quantitative single-cell Western blots, another group determined calretinin to be the predominant calcium-binding protein in tall hair cells of the frog sacculus, reaching concentrations of around $1.2 \mathrm{mM}$ (Edmonds et al., 2000). In this study, the authors proved that addition of $1.2 \mathrm{mM}$ calretinin in the pipette when recording in the whole cell configuration restored the endogenous buffering capacity of hair cells, measured by the activation curve of BK channels in perforated patch (Edmonds et al., 2000).

Recently, the concentration of these proteins in the mammalian cochlea was determined using immunogold tissue counts calibrated against gels containing known amounts of these proteins. The results showed that in rats with fully developed hearing, IHCs had 1/10 of the proteinaceous calcium buffer of OHCs, whose cell bodies contained oncomodulin and calbindin at levels equivalent to $5 \mathrm{mM}$ calcium-binding sites. The sum of the calcium buffers decreased in IHCs and increased in OHCs as the cells acquired their mature properties during development (Hackney et al., 2005).

\section{Developmental changes in hair cells}

The time period between conception and hearing onset varies widely for different mammalian species. In precocial animals, which have relatively long gestational 
periods, such as primates, cats and guinea pigs, hearing begins in the late prenatal stages or at birth. On the contrary, in altricial species, like mouse, hamster, rat, ferret and gerbil, the gestational period is short and hearing does not begin until at least 10 days after birth (Echteler, 1992). In our discussion of developmental changes during ontogeny of the hearing organ, we will try to restrict ourselves to the mouse where onset of hearing occurs at around postnatal day 12 (P12).

At birth, in the gerbil cochlea most spiral ganglion neurons display peripheral arbors that embrace both inner and outer hair cells. By P6, however, the arbors of individual cochlear afferents become confined to either the inner or outer hair cell zone, and thus there is a complete segregation of afferent innervation. Afferent neurons contacting IHCs still contact a few hair cells. During the second postnatal week, IHCs arbors undergo extensive pruning, resulting in the punctate bouton endings that characterize adult mammalian $\mathrm{IHC}$ afferents. At the end of this maturational process, individual IHCs are contacted by single unbranched afferents, each of which terminates in a single synapse while the $\mathrm{OHCs}$ retain a more branched innervation pattern from type II spiral afferents, each of which projects for hundreds of micrometers before branching and contacting a few OHCs (Echteler, 1992).

The efferent innervation of the cochlea originates in the superior olivary complex (SOC) in the brainstem. This projection arises from two sets of olivocochlear neurons, the lateral (LOC) and the medial (MOC), according to neuronal localization in the brainstem, morphology and target of these neurons in the organ of Corti. LOC fibers arise from LSO, are unmyelinated and terminate at the afferent fibers below 
IHCs while MOC fibers originate from the VNTB neurons, are myelinated and make synaptic contacts with the basolateral portion of the OHCs.

In the hamster, the medial section of the olivocochlear bundle apparently contacts first the IHCs around P1-P3 and later reaches the OHCs (Simmons et al., 1996). However, whether the lateral system arrives after or before the medial system still remains controversial (Simmons et al., 1996 but see Bruce et al., 2000). In the mouse, by P7 the first efferent endings are noted below the OHCs. By P9 efferent fibers are already making synapses onto $\mathrm{OHCs}$ and from then on the $\mathrm{OHC}$ afferent innervation subsides (Shnerson et al., 1981). It has been suggested that at birth only afferent fibers contact OHCs, and that by the end of the first postnatal week, the efferent olivo-cochlear fibers reach the pole of the OHCs competing for the same synaptic sites with the afferent fibers which then retract (Lenoir et al., 1980; Simmons et al., 1996). However, there is evidence both in favour and against this competition model (Pujol \& Carlier, 1982; but see Liberman et al., 2000).

At 2-3 days of birth afferent synapses were already present at mouse IHCs but ribbons were not always seen opposing afferent boutons. During the first 5 days the number of ribbons in $\mathrm{IHCs}$ and $\mathrm{OHCs}$ is comparable but during the next days pruning of ribbons in OHCs leaves just $20 \%$ of the initial number (Sobkowicz et al., 1982). Well defined efferent axo-somatic synapses are evident through 9 days of age in IHCs. Efferents contacted both the hair cell body or the afferents, and in the former case a postsynaptic cistern was generally recognizable in the IHC soma. Some efferents still contacted the IHC soma after P12 but in that case no postsynaptic cistern could be seen (Shnerson et al., 1981). It seems that the hair cell 
rather than the nerve fiber determines the occurrence and locus of the ribbons (Sobkowicz et al., 1982).

Inner ear efferents in mammals are neurochemically heterogeneous. In mammals acetylcholine (ACh), $\gamma$-aminobutyric acid (GABA) and dopamine (DA) are found in some efferent cell bodies and terminals together with several neuropeptides such as calcitonin gene-related peptide (CGRP), enkephalins and dynorphins, but their function is unknown (Simmons, 2002).

In mature rodent $\mathrm{OHCs}, \mathrm{ACh}$ released from the axosomatic medial efferent terminals elicits $\mathrm{Ca}^{2+}$ influx through ionotropic $\alpha 9 \alpha 10$ cholinergic receptors, which is followed by a larger $\mathrm{K}^{+}$efflux through nearby apamin sensitive SK2 potassium channels (Elgoyhen et al., 1994, 2001; Oliver et al., 2000).

A transient cholinergic innervation of IHCs involving the interplay of AChR and SK2 channels has been described for immature rats as well (Glowatzki \& Fuchs, 2000). By P16 cholinergic sensitivity is severely reduced and efferent synaptic activity is undetectable in these cells. Both $\alpha 9$ and $\alpha 10$ mRNA are expressed by adult OHCs but IHCs cease to express $\alpha 10$ mRNA at about the onset of hearing while continuing to express $\alpha 9$ into adulthood. However, fully functional cholinergic receptors at efferent synapses seem to require coassembly of both subunits. In addition, no immunoreactivity for SK2 could be detected after the onset of hearing, further supporting the developmental loss of this cholinergic synapse (Katz et al., 2004).

What is the function of the cochlear efferent innervation? In adult animals, activation of cochlear efferent neurons results in suppression of auditory nerve fiber responses (Wiederhold \& Kiang, 1970) and this effect is produced by the crossed projections of 
the medial efferent system to the OHCs (Warren \& Liberman, 1989). Immature IHCs rhythmically fire $\mathrm{Ca}^{2+}$ action potentials during early development (Kros et al., 1998; Glowatzki \& Fuchs, 2000; Beutner \& Moser, 2001) and exogenously applied ACh completely eliminates these action potentials. Glowatzki and Fuchs (2000) suggested that cholinergic inhibition of IHCs could impose rhythmicity onto the auditory pathway. Consistent with this idea, rhythmic firing ceases and becomes continuous when neonatal cats are de-efferented (Walsh et al., 1998). Rhythmic spontaneous electrical activity has been observed in the immature auditory pathway of a number of species (Walsh \& McGee, 1988). Patterned electrical activity has been previously involved in activity-dependent synaptic differentiation and refinement of visual circuits (Cabelli et al., 1995) and could play a similar role in the auditory system. Cholinergic input to OHCs hyperpolarizes these cells, in turn affecting their electromotile responses and thereby decreasing cochlear mechanical responses to low-level sounds and increasing auditory thresholds. It has been postulated that the efferent system could thus protect OHCs from acoustic injury; transgenic animals overexpressing $\alpha 9$ in $\mathrm{OHCs}$ were more resistant to noise exposure without showing changes in pre-exposure sensitivity (Maison et al., 2002). IHCs from the mouse undergo major developmental changes during the second postnatal week. Immature IHCs mainly fire $\mathrm{Ca}^{2+}$ action potentials that support neurotransmitter release, which disappear around the onset of hearing due to the expression of fast-activating BK channels (Kros et al., 1998; Beutner \& Moser, 2001). Mature IHCs respond to sound stimulation with graded receptor potentials that increase with sound intensity from around P12 (Russell \& Sellick, 1978). At the 
onset of hearing, the synaptic machinery changes from multiple spherical bodies, typical of immature cells, to single flat plate-like ribbons at each active zone (Sobkowicz et al., 1982). In addition to these morphological findings, the onset of functional maturation in the cochlea is also characterized by an increase in the efficiency with which $\mathrm{Ca}^{2+}$ triggers exocytosis of the RRP (Beutner \& Moser, 2001; Johnson et al., 2005).

The receptor potential in mature IHCs is shaped by BK and $\mathrm{K}_{\mathrm{v}}$-type $\mathrm{K}^{+}$channels (Kros \& Crawford, 1990). In addition to these conductances, an additional $\mathrm{K}^{+}$current mediated by KCNQ-type channels is substantially active at the resting membrane potential of these cells and deactivates on hyperpolarization. As shown by blocking this current, it can set the resting membrane potential and consequently maintain low intracellular levels of $\mathrm{Ca}^{2+}$ by favoring the closed state of $\mathrm{Ca}^{2+}$ channels (Oliver et al., 2003).

\section{Thyroid hormone action}

Thyroid hormone $(\mathrm{TH})$ has major effects on the developing brain in utero and during the neonatal period. Neonatal hypothyroidism due to genetic causes and iodine deficiency in humans causes mental retardation and neurological defects (reviewed in Yen, 2001).

Studies indicate that short periods of TH deficiency, when established during the critical time window before the onset of hearing at postnatal day 12 (P12) lead to permanent hearing impairment. This was made evident by significantly increased 
auditory thresholds in TH-deprived mice even 9 months after suspension of $\mathrm{TH}$ deficiency. Other TH-dependent maturational processes in the organ of Corti like the formation of the inner sulcus or the synaptogenesis of efferent fibres are unaffected by this short deprivation, revealing a very specific timing of the sensitivity to $\mathrm{TH}$ in different structures (Knipper et al., 2000).

Thyroid receptors (TRs) belong to a superfamily of ligand-responsive transcription factors that includes receptors for retinoids and steroids. Members of this family induce or repress transcription by binding to cis-acting elements associated to target genes, called thyroid responsive elements (TRE).

Two genes encoding the TR $\alpha$ and TR $\beta$ receptors, $\alpha$ and $\beta$ c-erbA, are conserved across vertebrate species. The distribution of isotypes of these gene families varies according to the cell type. The TR $\alpha$ gene encodes a TH-responsive receptor, TR $\alpha 1$, and a C-terminal splice variant, TR $\alpha 2$, of unknown function that does not bind $\mathrm{TH}$. TR $\alpha 1$, for instance, has a wide expression pattern while TR $\beta$ receptors, in particular TR $\beta 2$ seem to be confined to the cochlea, retina and pituitary gland (Bradley et al., 1994; Forrest et al., 2002). TR $\alpha$ gene expression is also prominent in the developing cochlea but in contrast to $\operatorname{TR} \beta$, it is also found in inner ear structures responsible for balance (Bradley et al., 1994). Deafness in children homozygous for a large deletion of the TR $\beta$ gene suggests that cochlear $\alpha 1$ TRs cannot functionally compensate for the absence of $\beta 1$ and $\beta 2$ (Takeda et al., 1991; 1992).

Furthermore, gene targeting studies in mice indicated that deletion of the TR $\beta$ receptor, but not of the TR $\alpha$ receptor, causes deafness, revealing its crucial role in auditory development (Forrest et al., 1996). Furthermore, in these mice it was shown 
that $\mathrm{TH}$ controls the expression of $\mathrm{BK}$ currents in $\mathrm{IHCs}$ at the onset of hearing. Moreover, they did not display major histological defects and $\mathrm{OHC}$ electromotility, transducer currents and endocochlear potential were intact, indicating that a TR $\beta$ mediated transcriptional pathway is required for the physiological maturation of IHC (Rüsch et al., 1998). Although this current eventually appeared later in development, the animals remained hearing impaired, revealing a critical time window for the action of TH. Interestingly, deletion of the $\alpha$ subunit of the BK channel but not the $\beta$, led to progressive hearing impairment in mice, although the surprisingly mild deficit suggests that these channels may not be essential for hearing (Ruttiger et al., 2004). Combined deletion of $\operatorname{TR} \alpha$ and $\operatorname{TR} \beta$ receptors unmasked a role for $\operatorname{TR} \alpha 1$ that was not evident in mice lacking only TR $\alpha 1$ and showed that both receptors together control novel cochlear functions. These common functions included a major role in the formation of the tectorial membrane, the development of the endocochlear potential and the electromotility of OHCs (Rüsch et al., 2001).

Several features of the cochlear phenotype in these mice reflect delays rather than permanent defects, thus probably other signals or transcriptional pathways must set the ultimate developmental course for these events, whereas TRs confer correct timing. Conceivably, the maturation of auditory function must require proper sensory input during critical periods (Katz \& Shatz, 1996; Rüsch et al., 1998). A neonatal surge in serum TH has been documented in several species and thus TRs could change transcriptional programs in response to temporal signals provided by rises in TH levels during development (reviewed in Yen, 2001). 
The thyroid gland provides a systemic supply of thyroid hormone, mainly in the form of $\mathrm{T} 4$, which is then deiodinated in the tissues to $\mathrm{T} 3$, the main active form of the hormone, by specific enzymes called deiodinases. The majority of T3 in the brain is generated by the action of type 2 deiodinase rather than by uptake from the circulation. This enzyme is also expressed in the cochlea and its targeted deletion leads to hearing impairment (Campos-Barros et al., 2000; Ng et al., 2004).

Despite the importance of $\mathrm{TH}$ in brain and cochlear development, relatively few genes are known to be directly regulated by $\mathrm{TH}$. In a pharmacological model of hypothyroidism, rats treated with methyl-mercapto imidazol (MMI) showed a retardation in the expression of myelin markers like P0, MBP and PLP in glial cells surrounding the peripheral and proximal part of the VIIIth nerve, which normally are expressed simultaneously from P2 onwards, very early before onset of hearing (Knipper et al., 1998). Failure in achieving a proper myelinization of the acoustic nerve may explain the increased response latencies of the auditory brainstem responses $(A B R$, which represent synchronous neural activity generated at several levels of the ascending auditory pathway) in the same model of hypothyroidism (Knipper et al., 2000).

So far, apart from the already discussed regulation of BK channels in IHCs, the other two genes in the cochlea which are known to be under TH control are prestin and KCNQ4, both expressed in OHCs (KCNQ4 is also expressed in IHCs, see above). Expression of prestin was strongly reduced in the absence of $\mathrm{TH}$ and its subcellular distribution pattern was immature in hypothyroid rats (Weber et al., 2002). In contrast, expression of KCNQ4 strictly required the presence of $\mathrm{TH}$. In hypothyroid 
rats, KCNQ4 expression was repressed by apo-TR $\alpha$, the unliganded TR $\alpha$ receptor, but this effect could be removed upon binding of TH to this receptor (Winter et al., 2006).

\section{The Pax ${ }^{-/-}$athyroid mouse}

Little is known about the regulation of hair cell afferent synapse development and accompanying molecular changes. In this study, we wanted to specifically address the role played by $\mathrm{TH}$ in synaptogenesis. For our study of $\mathrm{TH}$ function in postnatal IHC differentiation we used mice lacking the transcription factor Pax8 (Mansouri et al., 1998). These mice serve as a model of human primary congenital hypothyroidism (Macchia, 2000; Kopp, 2002). They are athyroid because they do not form thyroid follicular cells (Mansouri et al., 1998). Their auditory system has recently been characterized in detail. Despite their deficiency, they survive up to P21. No auditory brainstem responses (ABR) to sound could be recorded in these mice at $130 \mathrm{~dB}$ SPL, even at P21 when hearing normally reaches adult sensitivity. Maturation of the inner ear seemed to be delayed by about 1 week in comparison with control littermates and the hearing deficit could be partially restored by postnatal substitution with T4, probably suggesting a prenatal component (Christ et al., 2004). An important advantage of this model is that knock-out mice are obtained by breeding euthyroid $\mathrm{Pax}^{+/-}$dams thereby avoiding the induction of maternal hypothyroidism, a common problem in pharmacological models where MMI or PTU is administered to pregnant dams. Wild-type pups are able to produce $\mathrm{TH}$ via their own thyroid gland activity from E17-E18 onward while TR $\alpha$ and $\operatorname{TR} \beta$ expression was 
observed in the neonatal otocyst as early as E14 in rats, thus leaving open the possibility that activation of fetal TRs via transfer of maternal thyroid hormone across the placenta could occur in athyroid mice, (Bradley et al., 1994; Knipper et al., 2000). Pax8 belongs to a family of transcription factors that are involved in morphogenesis and cell differentiation. 9 members are known to date and all share an evolutionary conserved 128-aa DNA-binding domain (Prd). They are expressed in the CNS in a stage and region specific manner. Pax8 is expressed in the otocyst, developing thyroid, kidney, spinal cord and the hindbrain-midbrain boundary (Stuart et al., 1994; Mansouri et al., 1996).

Other Pax transcription factors (Pax2 and Pax6) are also involved in early ear development, where they seem to compensate for the lack of Pax8 (Xu et al., 1999). Here, we studied the presynaptic function of TH-deficient IHCs and used confocal and electron microscopy to investigate the number and morphology of their ribbon synapses. Using quantitative RT-PCR we determined the mRNA levels of synaptic proteins in the organ of Corti during normal development and in case of $\mathrm{TH}$ deficiency. Our study shows that synapse maturation in IHCs is severely impaired in the absence of $\mathrm{TH}$.

\section{Materials and Methods}

\section{Animals}

The animals were maintained according to the animal welfare guidelines of the University of Goettingen and the state of lower Saxony. Pax $8^{+/-}$male and female mice were used for mating. For the $\mathrm{TH}$-substitution experiment $\mathrm{Pax}^{-/-}$mice received daily intraperitoneal injections of $0.3 \mu \mathrm{g}$ levo-thyroxine (Sigma-Aldrich, cell- 
culture tested) per gram body weight starting from the day of birth (Weber et al., 2002).

\section{Patch-clamp of IHCs}

IHCs from the apical coil of freshly dissected organs of Corti from Pax8-/- mice (mut) and their wt littermates or C57BL/6J mice (results of the latter two groups were pooled as they were statistically not distinguishable) were patch-clamped at room temperature $\left(20-25^{\circ} \mathrm{C}\right)$ on postnatal days $6-8$ (p6-8) and p14-16.

Chemicals were obtained from Sigma-Aldrich unless otherwise stated. The dissection solution (HEPES Hank's on ice) contained (in $\mathrm{mM}$ ): $5.36 \mathrm{KCl}, 141.7 \mathrm{NaCl}$, $1 \mathrm{MgCl}_{2}, 0.5 \mathrm{MgSO}_{4}, 0.1 \mathrm{CaCl}_{2}, 10 \mathrm{Na}$-HEPES, $10 \mathrm{D}$-glucose and 3.4 L-glutamine. The $\mathrm{pH}$ was adjusted to 7.2 with $\mathrm{NaOH}$ and the osmolarity was $290 \mathrm{mmol} / \mathrm{kg}$. For perforated-patch recordings of $\mathrm{Ca}^{2+}$ current and exocytosis:

1) The pipette solution contained (in $\mathrm{mM}$ ): 130 Cs-gluconate, 10 tetraethylammonium-Cl (TEA-Cl), 10 Cs-HEPES, 10 4-aminopyridine, 1 $\mathrm{MgCl}_{2}$ and amphotericin B $(250 \mu \mathrm{g} / \mathrm{ml}$, Calbiochem, La Jolla, CA $)$. The osmolarity was $290 \mathrm{mmol} / \mathrm{kg}$ and $\mathrm{pH}$ was adjusted to 7.2 with $\mathrm{HCl}$. With this solution, pipette resistances were around 4-6 $\mathrm{M} \Omega$.

2) The extracellular solution contained (in $\mathrm{mM}$ ): $113 \mathrm{NaCl}, 2 \mathrm{CaCl}_{2}, 35 \mathrm{TEA}-\mathrm{Cl}$, $2.8 \mathrm{KCl}, 1 \mathrm{MgCl}_{2}, 10 \mathrm{Na}-\mathrm{HEPES}$ and $10 \mathrm{D}$-glucose. Osmolarity was in the range $300-320 \mathrm{mmol} / \mathrm{kg}$ and $\mathrm{pH}$ was adjusted to 7.2 with $\mathrm{NaOH}$.

For standard whole-cell recordings of $\mathrm{K}+$ current and membrane potential: 
1) The pipette solution contained (in $\mathrm{mM}$ ): $135 \mathrm{KCl}, 1 \mathrm{MgCl}_{2}, 10 \mathrm{~K}-\mathrm{HEPES}, 2$ Mg-ATP, $0.3 \mathrm{Na}-\mathrm{GTP}$ and $0.1 \mathrm{EGTA}$. Osmolarity was $290 \mathrm{mmol} / \mathrm{kg}$ and $\mathrm{pH}$ was adjusted to 7.2 with $\mathrm{KOH}$. Pipettes filled with this solution had resistances in the range of 2.5-4 $\mathrm{M} \Omega$.

2) The extracellular solution contained (in $\mathrm{mM}$ ): $144 \mathrm{NaCl}, 5.8 \mathrm{KCl}, 2 \mathrm{CaCl}_{2}, 0.9$ $\mathrm{MgCl}_{2}, 10 \mathrm{HEPES}$ and $10 \mathrm{D}$-glucose. Osmolarity was $300-320 \mathrm{mmol} / \mathrm{kg}$ and $\mathrm{pH}$ was adjusted to 7.2 with $\mathrm{NaOH}$.

EPC-9 amplifiers (HEKA-electronics, Lambrecht, Germany) controlled by "Pulse" software (HEKA) were used for measurements. All voltages were corrected for liquid junction potentials $(-14 \mathrm{mV}$ for $\mathrm{Cs}$-gluconate and $-4.4 \mathrm{mV}$ for $\mathrm{KCl}$ intracellular solutions). For perforated-patch recordings of $\mathrm{Ca}^{2+}$ currents and exocytic $\Delta \mathrm{Cm}$ no series resistance $\left(R_{s}\right)$ compensation was performed but rather we discarded recordings with $R_{s}>30 \mathrm{M} \Omega$. Currents were low-pass filtered at $2 \mathrm{kHz}$ and sampled at $10 \mathrm{kHz}$. Cells that displayed a membrane current exceeding $-50 \mathrm{pA}$ at our standard holding potential of $-84 \mathrm{mV}$ were discarded. $\mathrm{Ca}^{2+}$ currents were further isolated from background current by 1.) subtracting a linear fit to the current-voltage relationships (IV) between $-74 \mathrm{mV}$ and $-64 \mathrm{mV}$ (for correction of $\mathrm{Ca}^{2+}$ current IV's) or 2.) a $\mathrm{P} / 6$ protocol (for $\mathrm{Ca}^{2+}$ currents used to elicit exocytosis). $\mathrm{Cm}$ was measured as described previously using the Lindau-Neher technique (Lindau and Neher, 1988; Moser and Beutner, 2000). $\Delta \mathrm{Cm}$ was estimated as the difference of the mean $\mathrm{Cm}$ over $400 \mathrm{~ms}$ following the depolarization (the initial $200 \mathrm{~ms}$ were skipped) and the mean pre-pulse capacitance $(400 \mathrm{~ms}) . \mathrm{Ca}^{2+}$ current integrals were calculated from the total depolarization-evoked inward current, including $\mathrm{Ca}^{2+}$ tail currents. 
For standard whole-cell recordings of $\mathrm{K}^{+}$currents and membrane potentials, $\mathrm{R}_{\mathrm{s}}$ was compensated on-line $(50-80 \%, .=10 \mu \mathrm{s})$ and the remaining voltage error was corrected off-line. Currents were low-pass filtered at $5 \mathrm{kHz}$ and sampled at $40 \mathrm{kHz}$. A $\mathrm{P} / 10$ protocol was used to subtract capacitive and ohmic background currents. For average values of $R_{s}$, resting $C m$ and resting current (at $-84 \mathrm{mV}$ ) see table 1 .

Data analysis was performed using Igor Pro software (Wavemetrics, Lake Oswego, Oregon). Means are provided \pm sem and were compared using an unpaired twotailed t-test with equal or unequal variances dependent on the result of Fisher's variance analysis.

\section{Immunocytochemistry}

The freshly dissected apical cochlear turns were fixed with either $4 \%$ paraformaldehyde (PFA) for 1 hour on ice (standard), with 99.9\% Ethanol (Merck, Darmstadt, Germany) for 20 min at $-20^{\circ} \mathrm{C}$ or with $99.9 \%$ Methanol (Merck) for 20 min at $-20^{\circ} \mathrm{C}$ (where specified in figure legends). Thereafter the preparations were washed $3 \times 10$ min in phosphate buffered saline and incubated for 1 hour in Goat Serum Dilution Buffer (GSDB, containing: 16\% normal goat serum, $450 \mathrm{mM} \mathrm{NaCl}$, $0.3 \%$ Triton $\mathrm{X}-100,20 \mathrm{mM}$ phosphate buffer, $\mathrm{pH}$ 7.4.) in a wet chamber at room temperature. Primary antibodies were dissolved in GSDB buffer and applied overnight at $+4^{\circ} \mathrm{C}$ in a wet chamber. After washing with wash buffer $(3 \times 10 \mathrm{~min})$ the organs of Corti were incubated with secondary antibodies in GSDB in a wet lightprotected chamber for 1 hour at room temperature. Then the preparations were washed $3 \times 10 \mathrm{~min}$ in wash buffer $(450 \mathrm{M} \mathrm{NaCl}, 20 \mathrm{mM}$ phosphate buffer, $0.3 \%$ Triton 
$\mathrm{X}-100$ ) and $1 \times 10 \mathrm{~min}$ in $5 \mathrm{mM}$ phosphate buffer, placed onto the glass microscope slides with a drop of fluorescence mounting medium (Dako A/S, Glostrup, Denmark) and covered with thin glass coverslips. The following antibodies were used: mouse IgG1 anti-CtBP2 (BD Biosciences, 1:100), rabbit anti-GluR2/3 (Chemicon, 1:100), mouse anti-parvalbumin (Swant, 1:500), rabbit anti-BK (Sigma, 1:200), mouse antisynaptophysin (Synaptic Systems, 1:200), rabbit anti-SK2 (Sigma, 1:200) and secondary AlexaFluor488- and AlexaFluor568-labeled antibodies (Invitrogen, 1:200).

\section{Confocal microscopy}

Confocal images were acquired using a laser scanning confocal microscope LSM 510 (Carl Zeiss Jena, Germany) with $488 \mathrm{~nm}(\mathrm{Ar})$ and $543 \mathrm{~nm}(\mathrm{He}-\mathrm{Ne}$ ) lasers for excitation. We used 40x water immersion objectives and the bandpass filters 500 550 and $565-615 \mathrm{~nm}$. To produce 3D reconstructions of the specimen a z-axis stack of $2 \mathrm{D}$ images was taken with a step size of $0.2 \mu \mathrm{m}$. The pixel size was $0.09 \times 0.09$ $\mu \mathrm{m}$.

\section{Image analysis}

Images were processed using LSM 510 software (Carl Zeiss Jena) or ImageJ and assembled for display in Adobe Photoshop and Illustrator software. Whole mount preparations of the organ of Corti provided the possibility to analyze several IHCs in a row (Khimich et al., 2005). The RIBEYE immunofluorescence spots in the basolateral portion of the IHCs (up to the apical end of the CtBP2 stained nucleus) were counted in 3D reconstructions of the organ of Corti and divided by the number 
of IHCs (number of nuclei in the field of view). Likewise, we counted SK2 immunospots and related them to the number of IHCs in the field of view (identified by their halo of synaptophysin fluorescence) or to the average count of $5.2 \pm 0.72$ IHCs in the field of view (40x objective lens and 5x optical zoom, (Nemzou et al., 2006). Quantitative data are presented as mean \pm sem.

\section{Electron microscopy}

The organs of Corti were fixed immediately after dissection with $2.5 \%$ glutaraldehyde in HEPES-Hanks solution (see above) for $30 \mathrm{~min}$ at room temperature. Thereafter, the samples were fixed over night at $4^{\circ} \mathrm{C}$ in $2 \%$ glutaraldehyde in $0.1 \mathrm{M}$ cacodylic buffer at $\mathrm{pH}$ 7.4. After an additional fixation in $0.1 \% \mathrm{OsO} 4$ the samples were stained with $1 \%$ uranyl acetate, dehydrated in a series of $\mathrm{EtOH}$ and finally in propylene oxide. They were then embedded in Agar 100 (purchased through Science Services, Munich, Germany). Thin sections (80nm) were counterstained with lead citrate and examined using a Philips CM 120 BioTwin transmission electron microscope (Philips Inc., Eindhoven, Netherlands). Pictures were taken with a TemCam F224A camera (TVIPS, Gauting, Germany) at 20,000-fold magnification.

\section{Real-time RT-PCR}

We isolated total RNA from 6 organs of Corti (as well as 6 modioli, 6 retinae and 3 cerebella) from p14-17 $\mathrm{Pax}^{+/+}$and $\mathrm{Pax}^{-/-}$littermates (3 mice each) as well as $3 \mathrm{p} 6$ $\mathrm{Pax}^{+/+}$mice for each experiment using TRIzol Reagent (Invitrogen). Reverse transcription $\left(10 \mathrm{~min}\right.$ at $25^{\circ} \mathrm{C}, 50 \mathrm{~min}$ at $42^{\circ} \mathrm{C}$ and $15 \mathrm{~min}$ at $70^{\circ} \mathrm{C}$ ) of the total RNA 
(adjusted to approximately $1.5 \mu \mathrm{g}$ per reaction, except for the organ of Corti, where we used all isolated RNA, see results) was performed in first strand cDNA synthesis mix containing (after the final dilution in $\mathrm{mM}$ ) 50 Tris- $\mathrm{HCl}, 75 \mathrm{KCl}, 5 \mathrm{MgCl}_{2}$ and 5 DTT adjusted to $\mathrm{pH} 8.3$ and 100 units of SuperScript ${ }^{\mathrm{TM}}$ II Reverse Transcriptase (Invitrogen), 40 units RNaseOUT ${ }^{\mathrm{TM}}$ Ribonuclease inhibitor (Invitrogen) as well as 2.5ng/ $\mu \mathrm{l}$ random hexamers (Applied Biosystems). Following the RT reaction, cDNA was subjected to real-time PCR using ABI Prism 7000 or 7500 Sequence Detection Systems (Applied Biosystems). cDNAs for otoferlin, KCNMA1, a1D (CaV1.3), RIBEYE, Bassoon, SNAP25, SNAP23, synaptobrevin 1 (VAMP1) and TBP (TATAbinding protein as a housekeeping gene) were selectively amplified (in triplicates) using commercially available TaqMan Gene Expression Assays (Mm00453306_m1, Mm00516078_m1, Mm01209910_m1, Mm01163439_m1, Mm01330351_mH, Mm00464451_m1, Mm01336180_m1, Mm00772307_m1 and Mm00446973_m1, respectively, purchased from Applied Biosystems) in separate reactions $(20 \mu \mathrm{l}$ volume) according to the manufacturer protocol. Relative amounts of target mRNAs, normalized to that of TBP, were calculated using the comparative 2- $\Delta \Delta \mathrm{Ct}$ method (Applied Biosystems) and reported as population estimate of the mRNA abundance $\pm 95 \%$ confidence interval. Significance of expression differences was tested the level of $\Delta \mathrm{Ct}$ values using a paired two-tailed t-test. The efficiency of amplification, as determined by linear regression of standard curves, was greater than $90 \%$ for all assays in all tissues. The slopes of the standard curves for the organ of Corti amounted $-3.49,-3.56,-3.33,-3.54,-3.41,-3.43,-3.45,-3.50$ and -3.40 for otoferlin, 
KCNMA1, a1D (CaV1.3), RIBEYE, Bassoon, SNAP23, SNAP25, synaptobrevin 1 and TBP, respectively.

\section{Results}

\section{Impaired maturation of presynaptic function in IHCs of athyroid mice}

To investigate the presynaptic function of $\mathrm{Pax}^{-{ }^{-}} \mathrm{IHCs}$, we performed perforated patch-clamp measurements of $\mathrm{Ca}^{2+}$ currents and exocytic capacitance changes $\left(\Delta \mathrm{C}_{\mathrm{m}}\right)$ in athyroid $\mathrm{Pax}^{-/-}$and wt $\mathrm{IHCs}$ on p6-8 (before onset of hearing in wt) and p14-16 (after onset of hearing in wt). Representative traces are shown in Fig.11. $\mathrm{Ca}^{2+}$ currents in wt IHCs were larger before than after onset of hearing (Figs. 11,12 \& 13), which is in line with previous data obtained from IHCs of Naval Medical Research Institute (NMRI: Beutner and Moser, 2001, C57BL/6: Brandt et al., 2003 and CD1 mice: Johnson et al., 2005). $\mathrm{Ca}^{2+}$ currents of Pax8 ${ }^{-/-} \mathrm{IHCs}$ were smaller than wt currents when compared on p6-8 $\left(p=0.0004, n=7\right.$ for Pax8 $8^{-/-} I H C s$ and $n=$ 12 for wt IHCs). However, the $\mathrm{Ca}^{2+}$ currents of athyroid Pax8 ${ }^{-/-} \mathrm{IHCs}$ were approximately 2.5-fold larger than those of wt IHCs when compared two weeks after birth (Figs. 11, $12 \& 13, p=0.0001, n=7$ for Pax $8^{-/}$IHCs and $n=12$ for wt IHCs). These organs of Corti appeared immature also in their light microscopical structure. In contrast, normal $\mathrm{Ca}^{2+}$ current amplitudes of $\mathrm{IHCs}$ and mature light microscopical appearance of the organ of Corti were observed in p15 Pax ${ }^{-/-}$mice that had been TH-substituted after birth (Figs. 11, $12 \& 13, \mathrm{n}=3 \mathrm{IHCs}, 3$ further recordings that did not meet the quality criterion showed similar findings). This suggests that the normal developmental reduction of Cav1.3 current had not taken place in the absence of $\mathrm{TH}$ 
at that time. This is further supported by similar findings obtained in a pharmacological hypothyroidism model (Brandt et al., 2007).
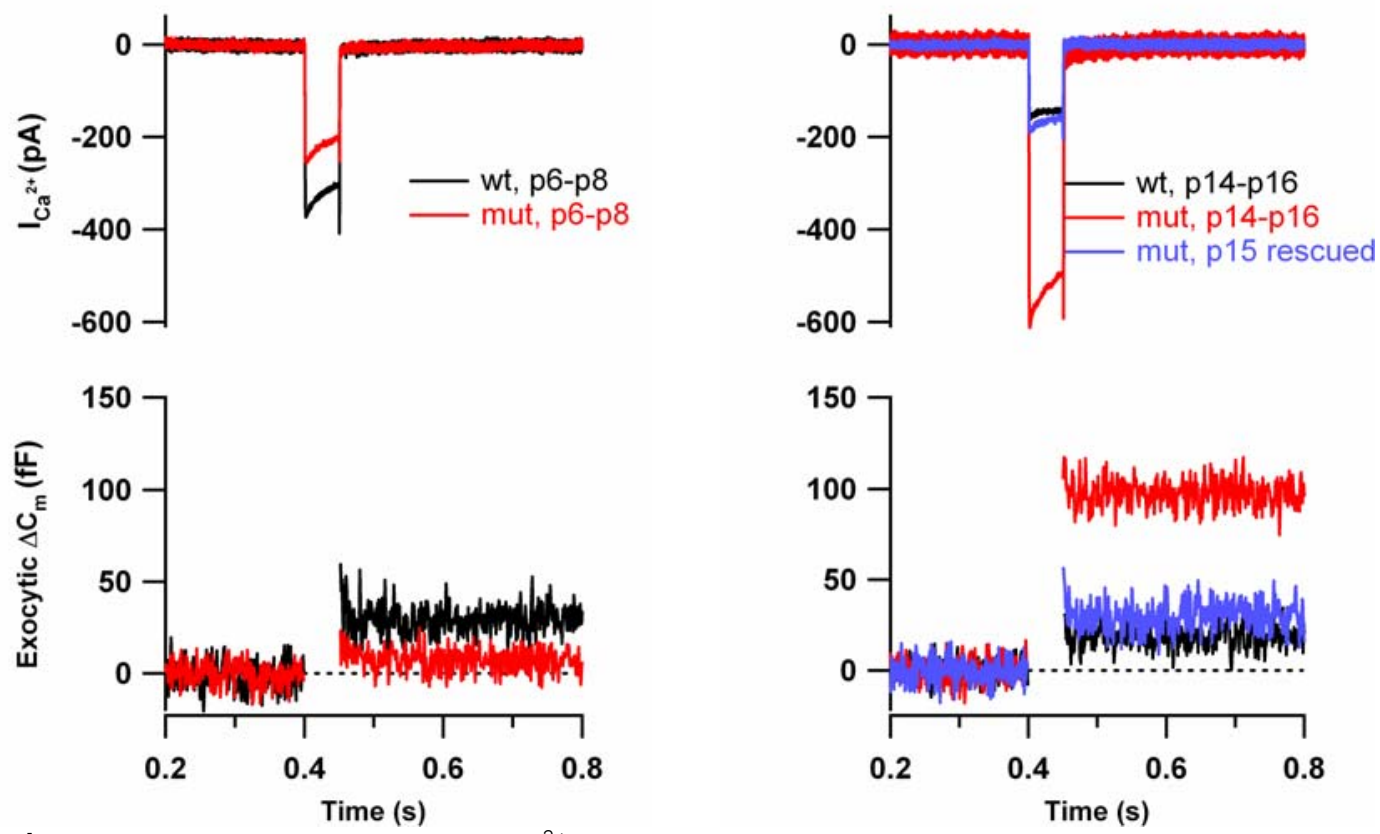

Fig. 11 Representative $\mathrm{Ca}^{2+}$ current traces ( $I_{\mathrm{Ca}}$, upper panel) and exocytic capacitance responses $\left(\Delta \mathrm{C}_{\mathrm{m}}\right.$, lower panel) for $\mathrm{p} 7$ (left) and $\mathrm{p} 15$ (right) mut (red), rescued mut (blue) and wt (black) IHCs elicited by step depolarization (50 ms) to $-14 \mathrm{mV}$ (peak $\mathrm{Ca}^{2+}$ current potential). The $\mathrm{R}_{\mathrm{s}}$ values were: $18.1 \mathrm{M} \Omega$ for wt $\mathrm{p} 7,20.1 \mathrm{M} \Omega$ for mut $\mathrm{p} 7,16.4 \mathrm{M} \Omega$ for wt $\mathrm{p} 15$, $20.8 \mathrm{M} \Omega$ for untreated mut $\mathrm{p} 15$ and $17.4 \mathrm{M} \Omega$ for $\mathrm{TH}$-treated mut $\mathrm{p} 15$.

The voltage dependence of the $\mathrm{Ca}^{2+}$ current in athyroid IHCs was comparable to wt IHCs on p14-16 but showed a somewhat more hyperpolarized peak potential in athyroid IHCs on p6-8 (Fig.12). Figure 13 plots the $\mathrm{Ca}^{2+}$ current integrals as a function of age for athyroid mut and wt IHCs (evoked by 25 ms depolarization to - 14 $\mathrm{mV}\left[-19 \mathrm{mV}\right.$ for $\mathrm{p} 6-8$ mutant IHCs] in $\left.2 \mathrm{mM}\left[\mathrm{Ca}^{2+}\right]_{\mathrm{e}}\right)$ together with results from NMRI IHCs (20 ms depolarization to $-5 \mathrm{mV}$ in $10 \mathrm{mM}\left[\mathrm{Ca}^{2+}\right]_{\mathrm{e}}$ ) after normalization to the p14-16 wt data. It emphasizes the delayed $\mathrm{Ca}^{2+}$ current up-regulation and lack of down-regulation up to $\mathrm{p} 15$ in $\mathrm{Pax}^{-/-}$IHCs unless TH-substituted. 


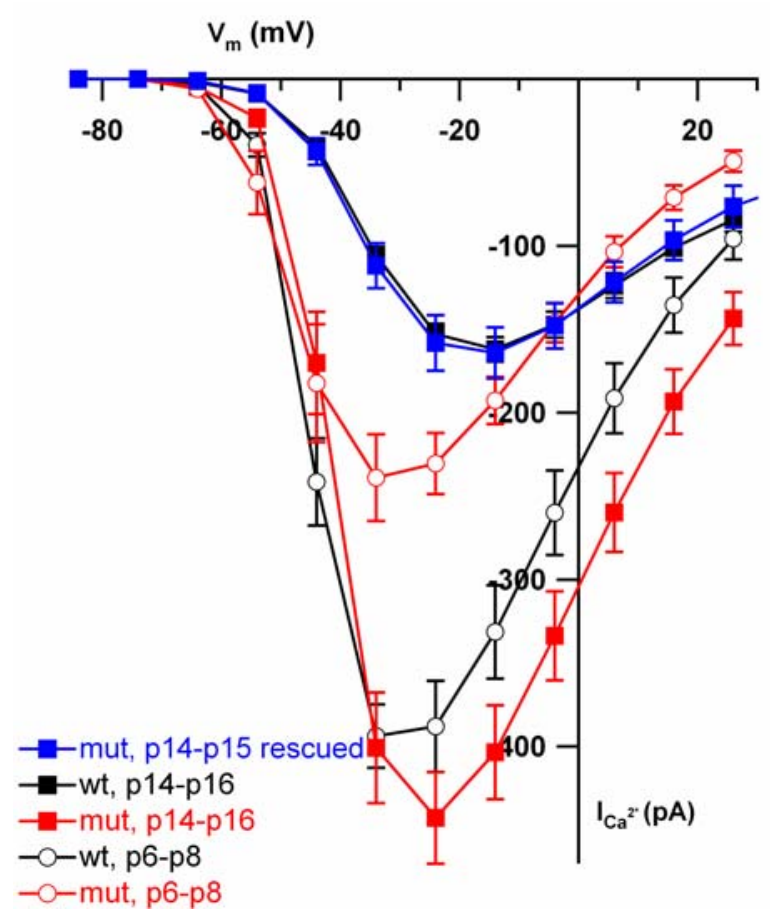

Fig. 12 Average current-voltage relationships (IV) recorded from wt ( $\mathrm{n}=$ 11 for p6-8, black open circles, $\mathrm{n}=9$ for $\mathrm{p} 14-16$, black solid squares) and $\mathrm{Pax}^{-1-}$ IHCS (athyroid: $\mathrm{n}=7$ IHCs for $\mathrm{p} 6-8$, red open circles and $\mathrm{n}=7$ IHCs for p14-16, red full squares; rescued: $n=3$ for $p 14-15$, blue solid squares) are displayed.

Figure 13 also compares the corresponding exocytic $\Delta C_{m}$ responses that were again normalized to the p14-16 $\mathrm{Pax}^{+/+}$data. The large $\mathrm{Ca}^{2+}$ current in $\mathrm{p} 14-16$ athyroid IHCs elicited robust exocytosis exceeding the responses of wt mice when probing $\Delta \mathrm{C}_{\mathrm{m}}$ with step depolarizations of $25 \mathrm{~ms}$ or longer duration (Figure 11, 13 and $14 \mathrm{~A}, \mathrm{p}$ $=0.002$ for 50 ms stimuli, $n=7$ for Pax8 $8^{-/-} \mathrm{IHCs}$ and $\mathrm{n}=12$ for wt IHCs). Sustained exocytosis, involving serial re-supply of vesicles to the active zones and parallel extrasynaptic turnover of synaptic vesicles, depends on long distance $\mathrm{Ca}^{2+}$ signaling (review in Nouvian et al., 2006) and was sufficiently recruited by the large $\mathrm{Ca}^{2+}$ currents in p14-16 athyroid IHCs. Shorter stimuli, preferentially recruiting the readily releasable vesicle pool (RRP) in mature wt IHCs (Moser and Beutner, 2000), did not 
elicit more exocytosis in $\mathrm{p} 14-16$ athyroid IHCs Pax $8^{-{ }^{-}}(p=0.21$ for 10 ms stimuli, $n=$ 7 for $\mathrm{Pax}^{-/-} \mathrm{IHCs}$ and $\mathrm{n}=12$ for wt IHCs) despite the larger $\mathrm{Ca}^{2+}$ current amplitudes.

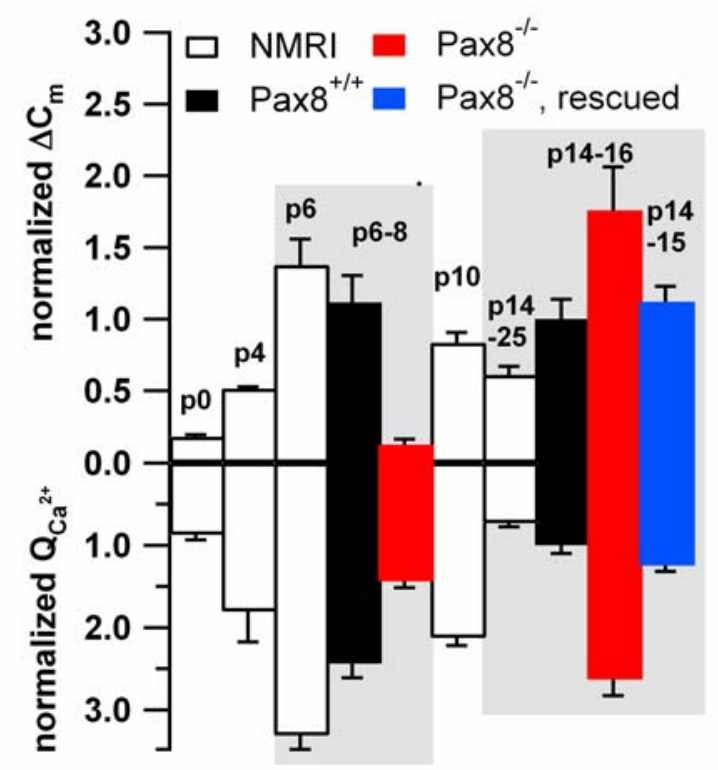

Fig. 13 Shows developmental changes of $\Delta \mathrm{C}_{\mathrm{m}}$ (upper panel) and $\mathrm{Ca}^{2+}$ current integral ( $Q_{c a}$, lower panel) in response to short depolarizations in IHCs from NMRI mice (white bars, data from Beutner and Moser, 2001), $\mathrm{Pax}^{+/+}$(or C57Black6; black, data as in Fig.14) and Pax ${ }^{-1}$ mice without (red) and with TH substitution (blue). All data have been normalized to the p14-16 $\mathrm{Pax}^{+/+}$ results.

This indicates that $\mathrm{Ca}^{2+}$ influx is less efficient in causing fast exocytosis in athyroid Pax $^{-/-} \mathrm{IHCs}$ at $\mathrm{p} 14-16$ than in mature wt IHCs. Figure 14B demonstrates this more directly by relating $\Delta \mathrm{C}_{\mathrm{m}}$ of $\mathrm{p} 14-16 \mathrm{Pax}^{-{ }^{-}}$and wt IHCs to the integrated $\mathrm{Ca}^{2+}$ influx showing a clear segregation of the two data sets for small $\mathrm{Ca}^{2+}$ current integrals. The exocytic efficiency was lower also in immature wt IHCs than in mature wt IHCs, which is in line with previous work (Beutner and Moser, 2001; Johnson et al., 2005). 
A

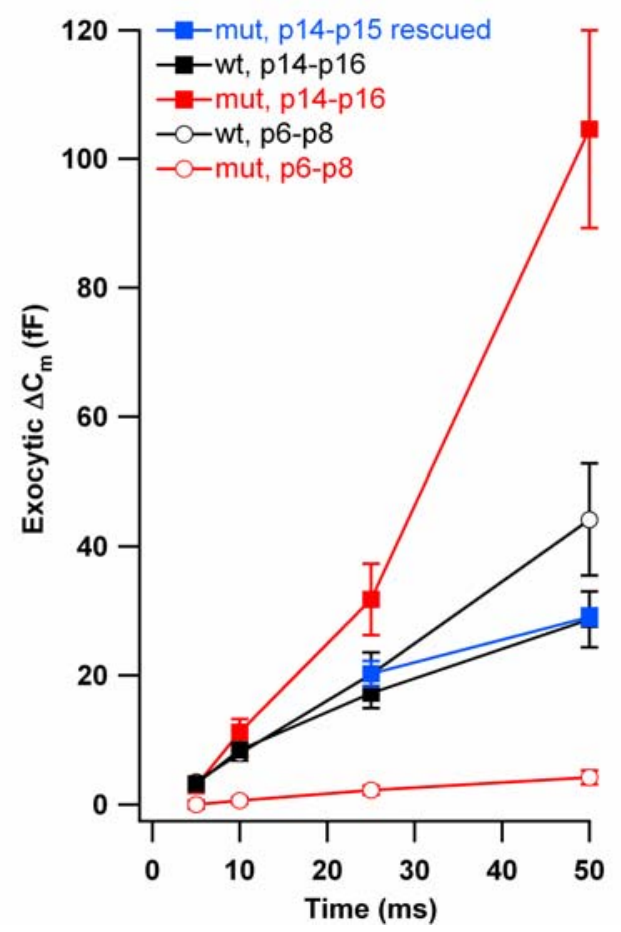

B

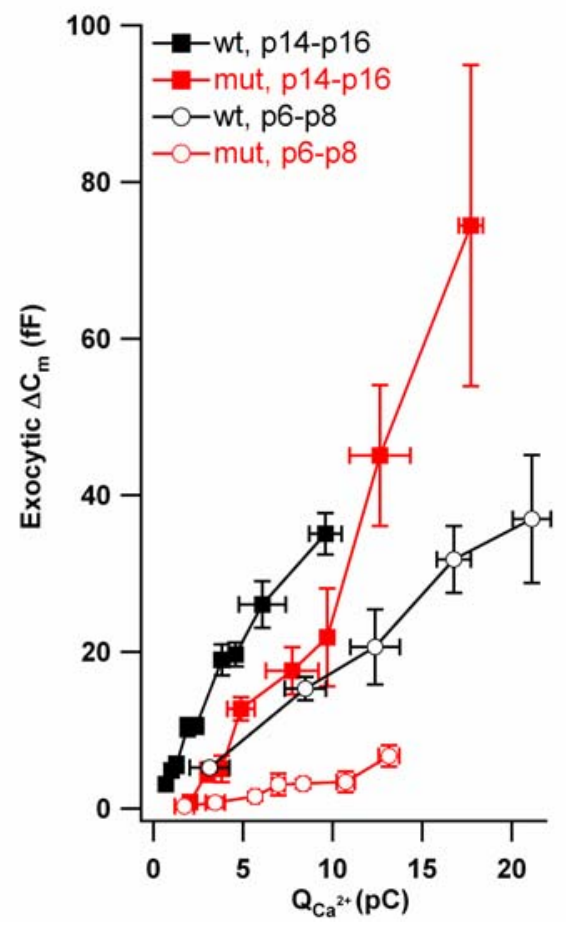

Fig. $14 \Delta \mathrm{C}_{\mathrm{m}}$ to depolarizations to the peak $\mathrm{Ca}^{2+}$ current potential having variable duration were recorded for wt $(n=12$ for $\mathrm{p} 6-8$; black open circles, $\mathrm{n}=12$ for $\mathrm{p} 14-16$; black full squares) and Pax8 ${ }^{-1-}$ IHCs (athyroid: $\mathrm{n}=7$ for $\mathrm{p} 6-8$; red open circles and $\mathrm{n}=7$ for $\mathrm{p} 14-16$; red full squares; $\mathrm{n}$ $=3$ for TH-rescued p14-16; blue full squares) were plotted $v s$. the stimulus duration $(\boldsymbol{A})$. B displays binned $\Delta \mathrm{C}_{\mathrm{m}}$ data $v s$. their corresponding $\mathrm{Q}_{\mathrm{ca}}$ of p6-8 and p14-16 wt and mut (untreated) IHCs. Intervals between the pulses were at least $30 \mathrm{~s}$ to allow for complete recovery of the readily releasable pool (Moser and Beutner, 2000).

Despite substantial $\mathrm{Ca}^{2+}$ currents we observed very little exocytosis in athyroid $\mathrm{IHCs}$ at p6-8 (Fig. 11,13 \& 14) for all but very long stimulus durations (e.g. 1 second, data not shown), resulting in the lowest exocytosis efficiency in our sample. The presynaptic dysfunction observed in IHCs of $\mathrm{Pax}^{-/-}$mice was specifically caused by the $\mathrm{TH}$ deficiency, as $\mathrm{TH}$ substitution restored normal $\mathrm{Ca}^{2+}$ currents and exocytic $\Delta \mathrm{C}_{\mathrm{m}}$ on postnatal day 15 in $\mathrm{Pax}^{-/-} \mathrm{IHCs}$. This is consistent with the (partial) restoration of hearing in $\mathrm{Pax}^{-/-}$mice following $\mathrm{TH}$-substitution (Christ et al., 2004). 
IHCs ribbon synapses are morphologically immature in athyroid Pax8 ${ }^{-/-}$ mice at p15

We analyzed the morphology of IHC ribbon synapses by confocal microscopy of immunolabeled organs of Corti as well as by electron microscopy. Ribbon synapses of mature IHCs can be readily identified as juxtaposed pairs of sharply delimited immunofluorescence spots of presynaptic RIBEYE (marking the ribbon) and postsynaptic glutamate receptors (GluR2/3, marking the postsynaptic density) by confocal microscopy (Khimich et al., 2005, Figure 15A). Different from this mature staining pattern in p14-15 wt and heterozygote IHCs (Fig. 15A) the GluR2/3 immunofluorescence was less confined in immature wt IHCs (p6-8, Fig. 15C) and athyroid IHCs (p14-15, Fig. 15B and p6, Fig. 15D). Their GluR2/3 immunofluorescence assumed a more confluent pattern enwrapping the basolateral pole of the IHCs and lacking the clear one-to-one juxtaposition to a corresponding ribbon (Fig. 15B-D, see also Nemzou et al. (2006) for a more detailed analysis throughout wt development).

Therefore, we did not attempt to quantify the number of postsynaptic boutons based on GluR-immunohistochemistry but rather focused on counting the number of RIBEYE immunofluorescence spots (Nemzou et al., 2006). IHCs of immature wt, p6 and $\mathrm{p} 14-15 \mathrm{Pax8}^{-/-}$organs of Corti showed comparable numbers of RIBEYE spots (Fig. 16B: p6-8 wt: $18.8 \pm 0.9$ per IHC, $n=47$ IHCs of 4 cochleae of 4 mice, p6 Pax8I-: $\sim 18$ per IHC, $\mathrm{n}=7.5 \mathrm{IHCs}$ of 2 cochleae of 1 mouse and $\mathrm{p} 14-15 \mathrm{Pax}^{-/-}: 22.5 \pm$ 0.5 per $\mathrm{IHC}, \mathrm{n}=39.5 \mathrm{IHCs}$, of 4 cochleae of 4 mice). These numbers clearly exceeded the counts in mature wt IHCs (Fig. 16B: p14-15, $14.11 \pm 0.27$ per IHC, $n=$ 
$47 \mathrm{IHCs}$ of 3 cochleae of 3 mice). We interpret this as a larger number of ribbons in the $\mathrm{p} 7$ wt and $\mathrm{p} 6$ as well as $\mathrm{p} 15 \mathrm{Pax}^{-/-} \mathrm{IHCs}$. In conclusion, the afferent synaptic organization of $\mathrm{p} 14-15 \mathrm{Pax}^{-/-} \mathrm{IHCs}$ was found to be immature with higher numbers of ribbons and less confined postsynaptic glutamate receptor immunoreactivity. A normal maturation of afferent synaptic organization could be largely restored in IHCs of p14-15 $\mathrm{Pax}^{-/-}$mice by TH substitution (Fig.16 A,B: RIBEYE immunofluorescence, 13.3 ribbons per $\mathrm{IHC}, \mathrm{n}=11.5 \mathrm{IHC}, \mathrm{n}=2$ organs of Corti of two mice).

Using electron microscopy we explored the ultrastructure of afferent synapses in IHCs of p14-15 wt (9 cochleae of 6 mice) and athyroid Pax ${ }^{-/-}$mice (6 cochleae of 4 mice). Qualitatively, we encountered many more afferent as well as efferent IHC synapses in the $\mathrm{Pax}^{-/-}$organs of Corti than in wt while sectioning the basolateral pole of IHCs. The afferent synaptic contacts of wt IHCs appeared clearly confined in space with one presynaptic vesicle cluster and, when hit, the corresponding ribbon facing a clearly delimited postsynaptic density (representative example in Figure $15 \mathrm{H})$. In contrast, the sections of athyroid IHC afferent synapses showed extended synaptic contacts more frequently displaying more than one presynaptic vesicle cluster and ribbon (e.g. Fig. 15I; 11 multi-ribbon active zones of 45 synapses in athyroid Pax $8^{-/-}$mice vs. 1 multi-ribbon active zone in 33 wt synapses). 


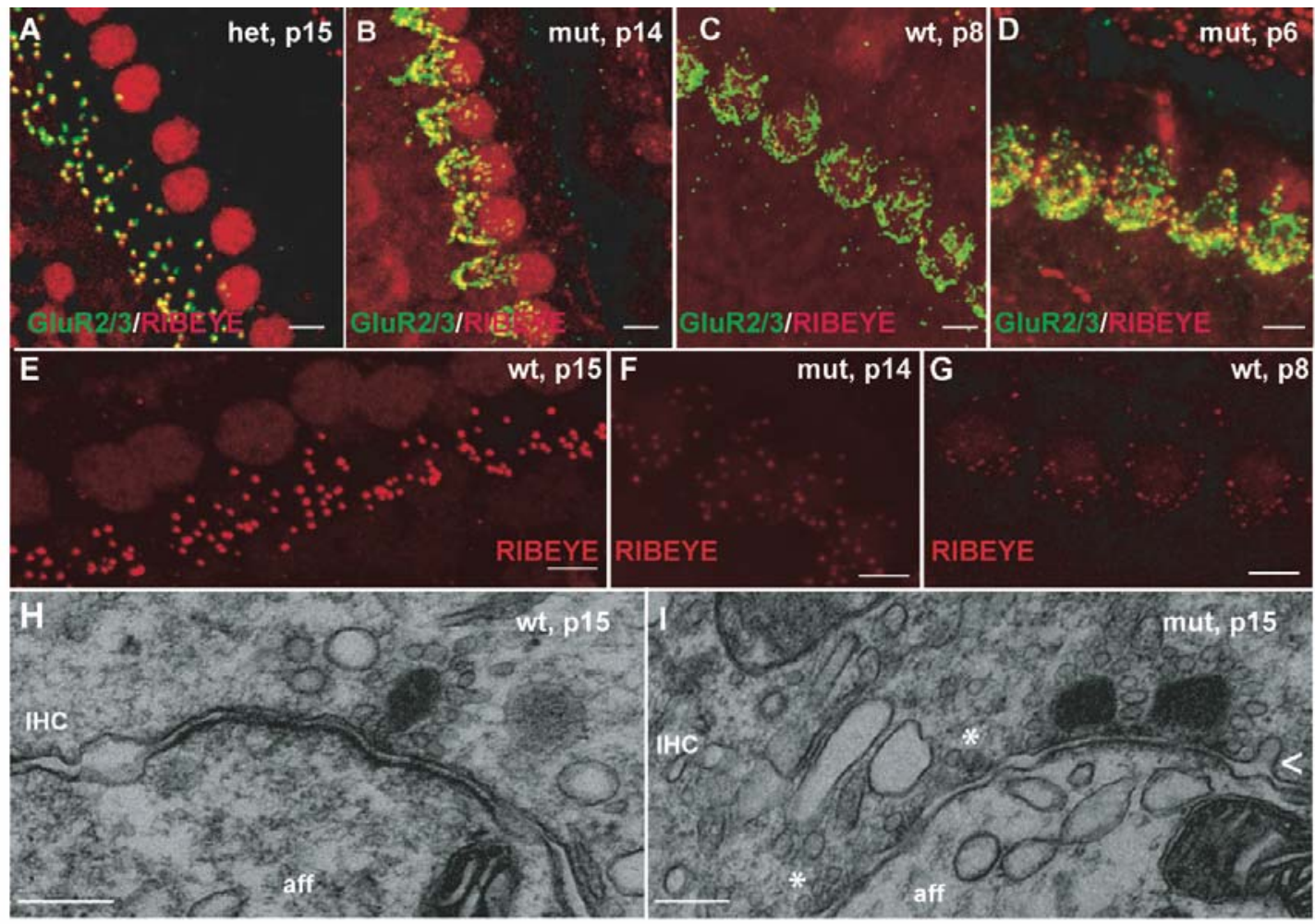

Fig. 15 Representative projections of confocal sections obtained from p15 heterozygote $(\boldsymbol{A})$, athyroid p14 mut $(\boldsymbol{B})$, p8 wt $(\boldsymbol{C})$ and p6 athyroid mut (D) organs of Corti stained for RIBEYE/CtBP2 (red) and GluR2/3 (green). Synaptic ribbons were identified as small RIBEYE positive spots juxtaposing GluR2/3 immunofluorescence spots in p15 wt IHCs (A). GluR2/3 immunofluorescence was less confined in athyroid p6 and p14 mut as well as p8 wt IHCS. E-G, red channel only, of comparable projections as used for counts of small RIBEYE positive spots in p15 wt $(E)$, p14 athyroid mut ( $F$ ) and p8 wt $(\boldsymbol{G})$ organs of Corti. In $(\boldsymbol{A}),(\boldsymbol{B}),(\boldsymbol{C})$ and $(\boldsymbol{E})$, specimens were fixed with paraformaldehyde $4 \%$ at room temperature. In (D), (F) and (G) MetoH $99 \%$ at $-20^{\circ} \mathrm{C}$ was used. $\boldsymbol{H}-\boldsymbol{I}$, electron micrographs of IHC ribbon synapses from p15 wt $(\boldsymbol{H})$ and p15 athyroid mut mice $(\boldsymbol{I})$. Synaptic ribbons are seen as electron-dense bodies each with a halo of synaptic vesicles and positioned close to the presynaptic membrane, opposing the postsynaptic density of the afferent fiber (aff). I shows an active zone representative for its large extension holding two ribbons and showing additional small vesicle clusters (asterisks). The arrowhead points towards a probably endocytic membrane invagination. In addition to the synaptic vesicles (small vesicles with rather homogeneous size), cisternae and tubes of varying size and shape as well as mitochondria were observed. Scale bars $5 \mu \mathrm{m}$ for panels $\boldsymbol{A}-\boldsymbol{G}$ and $200 \mathrm{~nm}$ for panels $\boldsymbol{H}-\boldsymbol{I}$.

Provided a sufficient separation the presence of multiple ribbons at the active zones might also contribute to the increased number of RIBEYE spots in athyroid IHCs. 
The postsynaptic membrane of mutant synapses often showed more than one density each facing a presynaptic ribbon/vesicle cluster. It is likely that these patchy postsynaptic densities indicate the presence of multiple glutamate receptor clusters of variable size in a given postsynaptic terminal. This, together with an increased total number of synapses, most likely accounts for the more confluent GluR2/3 immunofluorescence described above (Fig. 15B, D), which is also typical for immature wt IHCs (e.g. Fig. 15C and Nemzou et al., 2006).

A

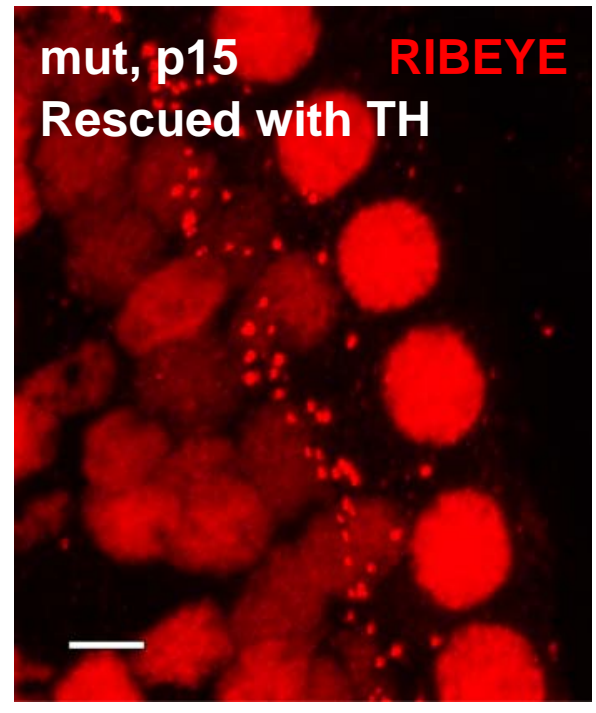

B

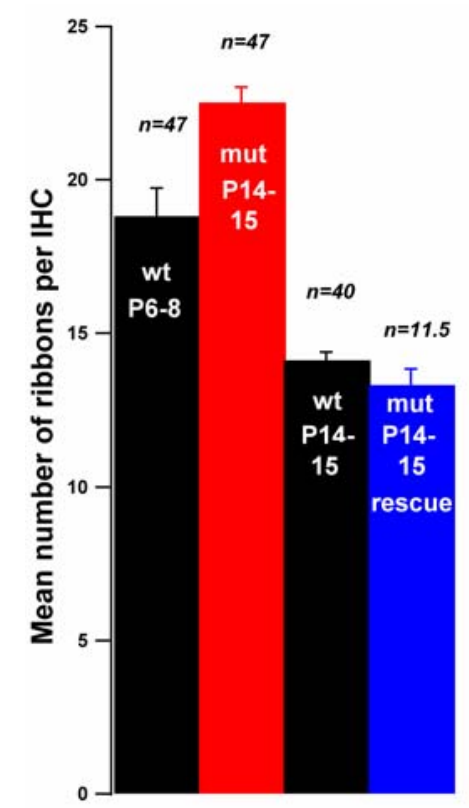

Fig.16 (A) shows a confocal image of a mut (p15) rescued with $\mathrm{TH}$ and stained for ribbons (RIBEYE). Scale bar is $5 \mu \mathrm{m}$. (B) The histogram shows the number of ribbons per IHC nucleus obtained from counting the ribbons in confocal sections as in $\boldsymbol{A}$, (see also Fig. 15) from wt p6-8 \& p14-15 (black), mut p14-15 untreated (red) and treated with TH (blue). The number of cells used for quantification is given above each bar.

$\mathrm{TH}$ regulates the expression of genes encoding synaptic proteins in the organ of Corti 
Little is known about the changes in molecular composition of the IHC's presynaptic active zone during development. Here, we used quantitative RT-PCR to explore whether and how the mRNA levels of synaptic proteins change in the wt organ of Corti from before ( $p 6)$ to after the onset of hearing ( $p 14-17)$. The analysis included otoferlin (synaptic vesicle $\mathrm{C}_{2}$-domain protein, Roux et al., 2006), Bassoon (cytomatrix protein of the active zone, tom Dieck et al., 1998; Khimich et al., 2005), RIBEYE (major ribbon component, Schmitz et al., 2000; Khimich et al., 2005), SNAP25 (neuronal tSNARE, Safieddine and Wenthold, 1999), SNAP23 (ubiquitously expressed tSNARE, Ravichandran et al., 1996), synaptobrevin 1 (vSNARE, Safieddine and Wenthold, 1999) and the Cav1.3 L-type Ca ${ }^{2+}$ channel (Platzer et al., 2000; Brandt et al., 2005). The relative RNA abundance of the individual genes differed to varying degrees among the tissues (differences were largest for RIBEYE and otoferlin mRNAs and smallest for SNAP25, data not shown).

In parallel, the analysis was run on organs of Corti from athyroid p14-17 Pax $8^{-1-}$ mice to investigate potential regulatory effects of $\mathrm{TH}$ on the expression of our genes of interest. We reasoned that the expression of genes encoding synaptic proteins in the IHC, which presents the major presynaptic element in the organ of Corti, would be represented well in these assays. We compared the results obtained in the organ of Corti to findings in the modiolus (mostly representing spiral ganglion neurons), the retina (containing ribbon and conventional synapses) and the cerebellum in order to evaluate how general effects of development and/or thyroid hormone signalling on the expression level of these genes might be. Several commonly used house keeping genes (e.g. ß-actin and GAPDH) had been previously shown to be 
regulated by TH (Poddar et al., 1996; Barroso et al., 1999) and, hence, could not be used here. TATA binding protein (TBP) mRNA was found to be comparably abundant in p6 and p14-17 wt as well as p14-17 Pax $8^{-/-}$organs of Corti (mean total RNA and Ct values of TBP: $1.8 \mu \mathrm{g}$ and 29.1 for $p 6 \mathrm{wt}, 0.8 \mu \mathrm{g}$ and 30.0 for $\mathrm{p} 14-17 \mathrm{wt}$ and $1.4 \mu \mathrm{g}$ and 29.6 for $\mathrm{p} 14-17 \mathrm{Pax}^{-{ }^{-}}$). The differences in total RNA and TBP Ct values most likely resulted from the varying efficiency of harvesting the organ of Corti between the three groups of animals. Therefore, we normalized the mRNA abundance for each gene of interest to TBP mRNA.

Figure 17A displays the mRNA levels of p14-17 organs of Corti of wt mice (black, $n$ $=24$ ears of 12 mice) and their Pax8 ${ }^{-/-}$littermates (red, $n=24$ ears of 12 mice) relative to those of $\mathrm{p} 6 \mathrm{Pax}^{+/+}$mice (set to $100 \%$, grey, $\mathrm{n}=24$ ears of 12 mice). During normal development we found a significant upregulation of SNAP25 $(p=$ $0.006)$, synaptobrevin $1(p=0.007)$ and Bassoon $(p=0.030)$ mRNAs as well as a trend towards higher mRNA levels in mature organs for otoferlin $(p=0.055)$. SNAP23 mRNA levels remained unchanged (p6: $100 \%$ [95\% Cl: 71...141\%], p1417: $90 \%$ [95\% Cl: $82 \ldots 100 \%])$. The mRNA levels of RIBEYE and Cav1.3 did not significantly drop despite the observed reduction of ribbon synapse number and of $\mathrm{Ca}^{2+}$ current (see below). The developmental $\mathrm{Ca}^{2+}$ current reduction may, therefore, be mediated by a regulation of Cav1.3 channel abundance on the posttranscriptional level. This could for example be achieved by changes of beta subunit expression affecting the Cav1.3 targeting to the plasma membrane (Herlitze et al., 2003). A developmental upregulation of SNAP25, synaptobrevin 1 and Bassoon was found also for the modiolus (Fig. 17B, $p=0.009, p=0.006$ and $p=0.007$, resp.) and 
the cerebellum (Fig. 17D, $p=0.006, p=0.012$ and $p=0.014$, resp.). The cerebellum further showed an increase in otoferlin mRNA levels during development $(p=0.027)$. In the retina (Fig. 17C), synaptobrevin 1 and RIBEYE were upregulated ( $p=0.012$ and $p=0.025$, resp.).

Organs of Corti of p14-17 Pax8 ${ }^{-/-}$mice showed lower mRNA levels for synaptobrevin $1(p=0.011)$, SNAP25 $(p=0.036)$ and Bassoon $(p=0.037)$ when compared to those of age-matched littermates. In contrast, the abundance of RIBEYE mRNA was increased $(p=0.008)$, which, most likely, relates to the supernumerous presence of ribbons in IHCs (and OHCs, data not shown). The SNAP23 mRNA abundance was unchanged $(95 \%[95 \% \mathrm{Cl}: 76 \ldots 111 \%])$. The TH-deficiency did not affect the abundance of the mRNAs of interest in the retina. However, the mRNA levels of SNAP25 and synaptobrevin 1 tended to be reduced in the cerebellum of p14-17 $\mathrm{Pax}^{-{ }^{-/}}$mice as were those of Bassoon and synaptobrevin 1 in modiolus, suggesting a delayed synaptic maturation of the conventional synapses in these tissues in the absence of $\mathrm{TH}$. 
A

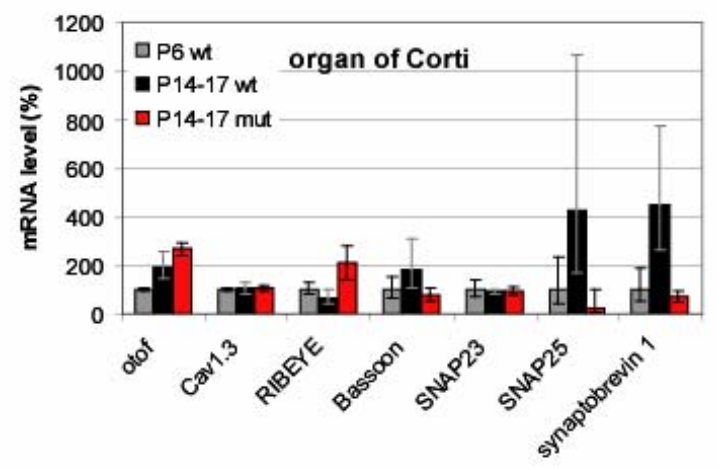

C

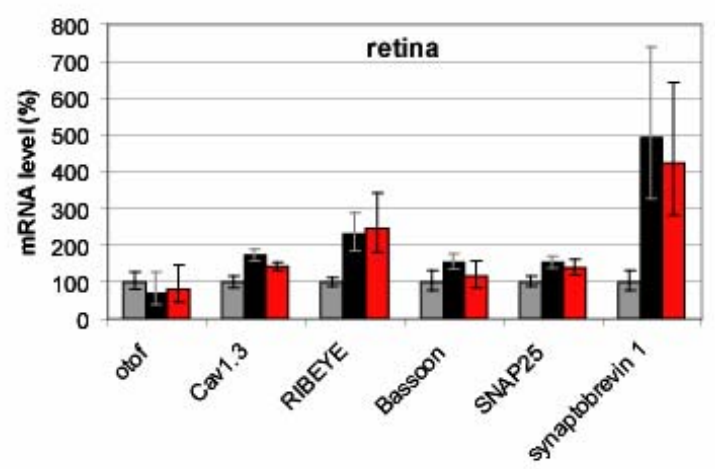

B

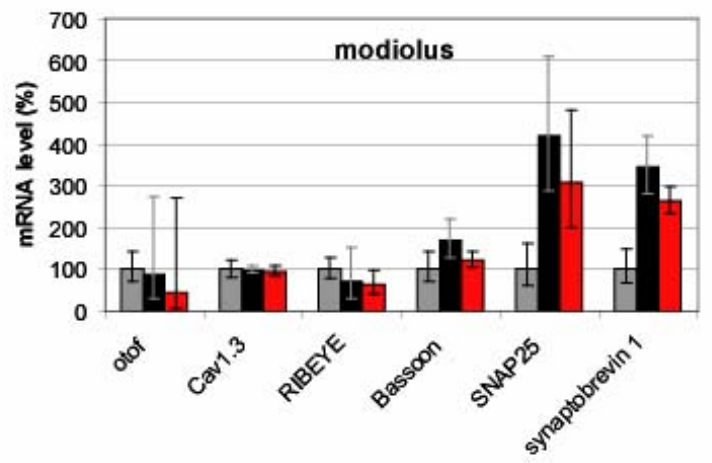

D

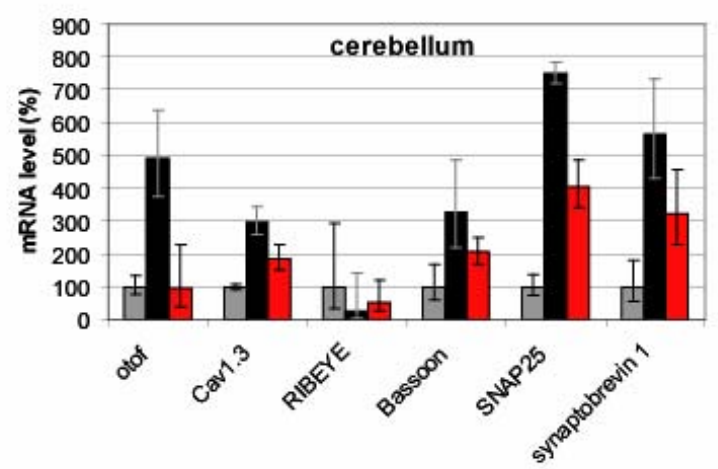

Fig.17 A-D show relative amounts of otoferlin, Cav1.3, RIBEYE, Bassoon, SNAP25, SNAP23 and synaptobrevin 1 mRNA estimated by quantitative RT-PCR. Total RNA was isolated from organ of Corti $(\boldsymbol{A})$, modiolus (B), retina (C) and cerebellum (D) of p6 Pax8 $8^{+/+}, \mathrm{p} 14-17 \mathrm{Pax}^{+/+}$and $\mathrm{p} 14-17 \mathrm{Pax}^{-/-}$mice ( $\mathrm{n}=$ 12 mice each). The expression of the target mRNAs was normalized first to that of TBP and then to the values obtained for corresponding mRNA and tissue of $\mathrm{p} 6 \mathrm{Pax}^{+/+}$mice. The data are represented as means from 4 independent experiments in which all samples were analyzed in triplicates (error bars indicate $95 \%$ confidence intervals of the population estimate of mRNA abundance).

\section{Lack of large conductance $\mathrm{Ca}^{2+}$-activated $\mathrm{K}^{+}$currents and $\mathrm{KCNQ}_{4}$ currents -Persistence of action potentials}

IHC sound coding requires rapid and graded transduction of the mechanical stimulus into a receptor potential. Large-conductance $\mathrm{Ca}^{2+}$-activated $\mathrm{K}^{+}$channels $(\mathrm{BK}$ channels) activate rapidly upon depolarization and increase the cell's conductance to several nanosiemens for fast dynamics of the cell's membrane potential in mature 
IHCs (Kros and Crawford, 1990; Oliver et al., 2006). BK channels are only acquired by IHCs around the onset of hearing (Kros et al., 1998; Langer et al., 2003) and this requires the presence of functional TH receptors (Rusch et al., 1998; Rusch et al., 2001). Figure 18 demonstrates the rapidly activating outward currents $\left(I_{K, f}\right)$ characteristic for currents mediated by BK channels in wt IHCs after the onset of hearing (top left, black trace, $n=6, p 14-16$ ), which were absent in $p 14-16 \mathrm{Pax}^{-/-}$ (top middle, red trace, $n=4$ ) and p6-8 wt (top right, black trace, $n=6$ ) IHCs. All three groups of IHCs displayed delayed rectifier potassium currents (top \& bottom panels), which were responsible for the residual current in $\mathrm{p} 14-16 \mathrm{Pax}^{-/-}$and $\mathrm{p} 6-8$ wt IHCs measured during 3 ms long depolarizations (Fig. 18, top panel and Fig. 19 left). We then used current-clamp recordings to study the resting membrane potential and the membrane potential responses to current injections (Table 1 and Fig. 20).

Table 1: Passive electrical properties

\begin{tabular}{l|l|c|c|c|c|c} 
& & $\mathbf{n u m}_{\text {IHCs }}$ & $\mathbf{C}_{\mathbf{m}}(\mathbf{p F})$ & $\mathbf{R}_{\mathbf{s}}(\mathbf{M} \mathbf{\Omega})$ & $\mathbf{I}_{\text {rest }}(\mathbf{p A})$ & $\mathbf{V}_{\mathbf{m}}(\mathbf{m V})$ \\
\hline $\mathbf{P 7}$ & $\mathbf{P a x 8}^{+/+}$ & $\mathrm{N}=12$ & $8.17 \pm 0.17$ & $22.5 \pm 1.42$ & $-47.98 \pm 2.64$ & $-70.96 \pm 2.04$ \\
\cline { 2 - 7 } & $\mathbf{P a x 8}^{-/-}$ & $\mathrm{N}=7$ & $6.60 \pm 0.22$ & $23.81 \pm 1.50$ & $-43.44 \pm 3.88$ & $\mathrm{ND}$ \\
\hline $\mathbf{P 1 5}$ & $\mathbf{P a x 8}^{+/+}$ & $\mathrm{N}=12$ & $8.80 \pm 0.30$ & $17.79 \pm 0.90$ & $-31.53 \pm 2.96$ & $-78.28 \pm 2.24$ \\
\cline { 2 - 7 } & Pax8 $^{-/-}$ & $\mathrm{N}=7$ & $7.39 \pm 0.25$ & $22.88 \pm 2.06$ & $-46.13 \pm 2.78$ & $-68.60 \pm 1.71$ \\
\hline
\end{tabular}

Table 1. Cell capacitance $\left(C_{m}\right)$ and series resistance $\left(R_{s}\right)$ of mutant and wildtype IHCs were repetitively estimated by time domain analysis of the cell's RC circuit during the recording in the perforated patch mode. $I_{\text {rest }}$ is the current at the holding potential of $-84 \mathrm{mV}$ and $\mathrm{V}_{\mathrm{m}}$ represents the IHC's membrane potential measured in whole-cell mode ( $n=3$ for each group in these experiments, $N D=$ not determined). $V_{m}$ values were corrected for the liquid junction potential of the $\mathrm{KCl}$ intracellular solution $(-4.4 \mathrm{mV})$. Data are presented as means of the averages of each individual IHC (grand average) \pm SEM. 

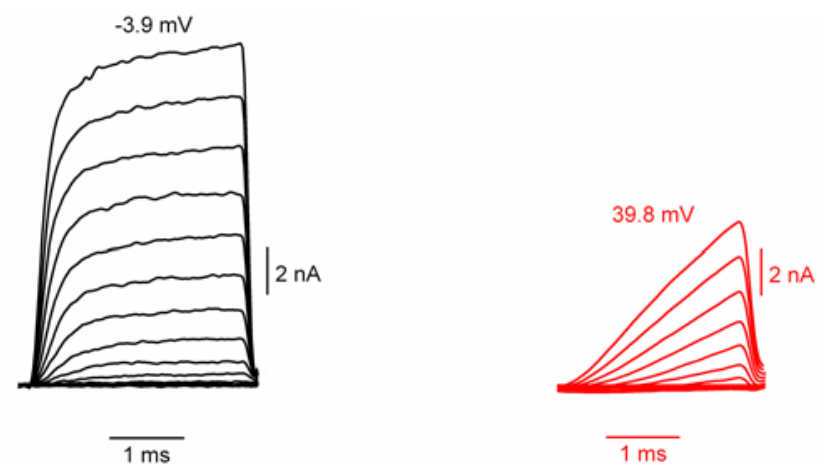

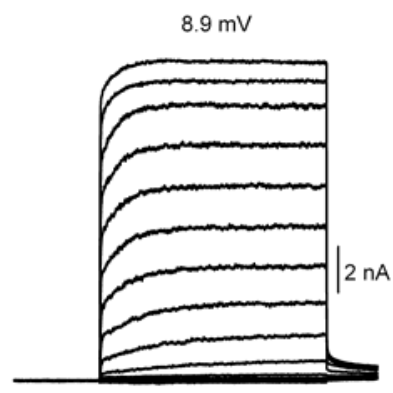

$\overline{20 \mathrm{~ms}}$

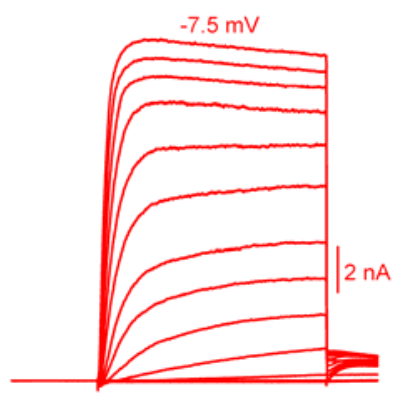

$\overline{20 \mathrm{~ms}}$

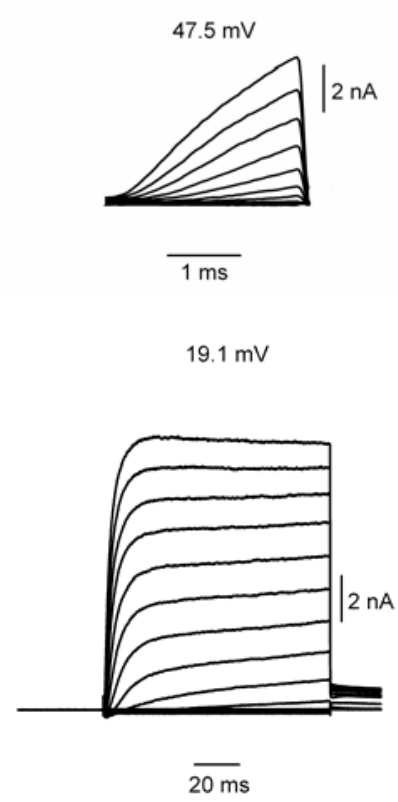

Fig. 18 Top row: $3 \mathrm{~ms}$ depolarizations (max. potential indicated) elicited fast outward currents (BK currents) in this p15 wt IHC (left) but neither in p15 mut (red, center) nor p7 wt (black, right) IHCs, which showed delayed rectifier currents only. $R_{\mathrm{s}}$ values were: $4.92 \mathrm{M} \Omega, 4.48 \mathrm{M} \Omega$ and 2.48 $M \Omega$ for wt p15, mut $\mathrm{p} 15$ and wt p7, respectively. Bottom row: large currents in all three groups in response to $100 \mathrm{~ms}$ voltage steps but lack of BK current in mut (red, center) and wt p7 (black, right) IHCs. $R_{s}$ values were: $3.16 \mathrm{M} \Omega, 4.27 \mathrm{M} \Omega$ and $3.96 \mathrm{M} \Omega$ for wt p15, mut p15 and wt p7, respectively.

The resting potentials were more depolarized in p14-16 Pax8 ${ }^{-/}$and p6-8 wt IHCs than in p14-16 wt IHCs (Table 1). Action potentials occurred spontaneously and/or upon injection of small depolarizing currents in p14-16 $\mathrm{Pax}^{-/-}$and p6-8 wt IHCs but not in p14-16 wt IHCs (Fig 20). $\mathrm{Ca}^{2+}$ action potentials persisted also in a pharmacological rat model of congenital hypothyroidism (Brandt et al., 2007). $\mathrm{KCNQ}_{4}$ currents, setting the resting membrane potential in mature IHCs (Oliver et al., 2003), were readily identified as slowly deactivating currents during hyperpolarization in p14-16 wt IHCs $(n=3)$. We failed to detect $\mathrm{KCNQ}_{4}$ currents in 
p14-16 Pax8 ${ }^{-/-} \mathrm{IHCs}$ (Fig. 19, right, $\mathrm{n}=3 \mathrm{IHCs}$ ). This probably accounts for the depolarized resting membrane potential in the mutant p14-16 IHCs. In addition to showing immature membrane currents, mutant p14-16 IHCs also displayed immature passive electrical properties (Table 1).
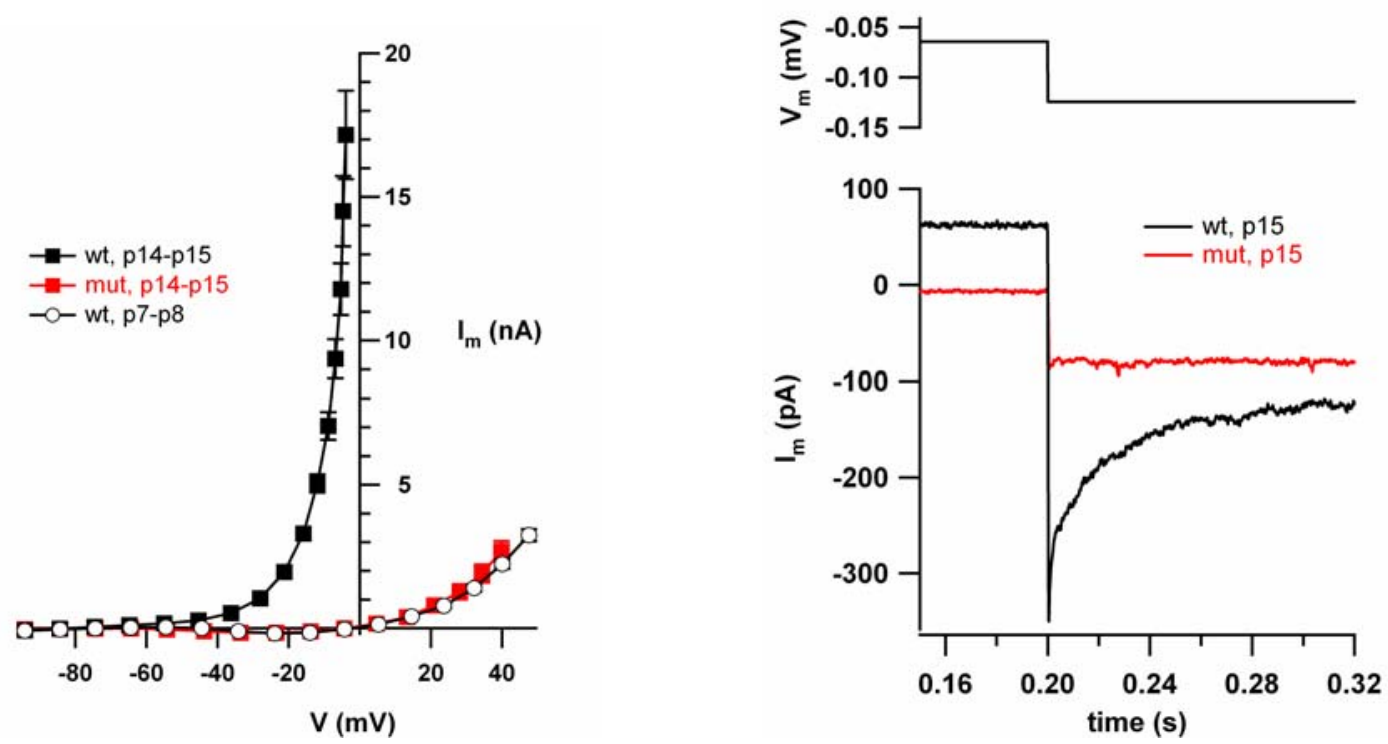

Fig. 19 Left: mean I-V relationship for $3 \mathrm{~ms}$ depolarizations, obtained by averaging currents for $1 \mathrm{~ms}$ (starting $1 \mathrm{~ms}$ after stimulus onset) in IHCs of p14-16 wt (black squares, $\mathrm{n}=6$ ) and $\mathrm{Pax}^{-1-}$ (red squares, $\mathrm{n}=4$ ) as well as p6-8 wt IHCs (black open circles, $n=6$ ). (Right) representative currents of a p15 wt IHC (black) and a p15 mut IHC (red) upon repolarization to $-154 \mathrm{mV}$ from $-64 \mathrm{mV}(200 \mathrm{~ms})$, clearly showing a deactivating current characteristic for $\mathrm{KCNQ}_{4}$ channels in the wt but not in the mut IHC, no $\mathrm{P} / \mathrm{n}$ correction applied, $R_{S}$ values were: $2.49 \mathrm{M} \Omega$ and 5.24 $\mathrm{M} \Omega$ for wt $\mathrm{p} 15$ and mut $\mathrm{p} 15$.
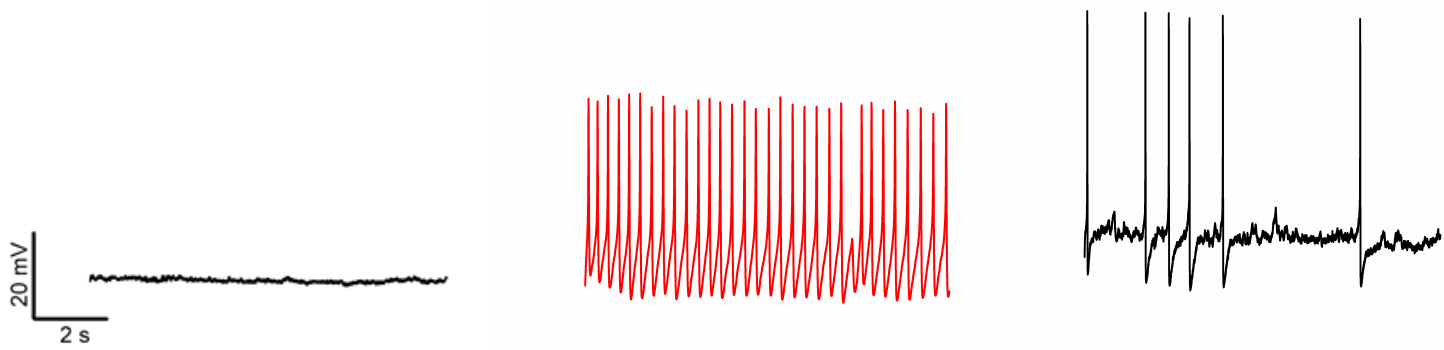

Fig. 20 Membrane potentials in response to injection of 50 pA (p15 wt, black left trace) and $10 \mathrm{pA}$ (p15 mut, red middle trace and p7 wt, black right trace) depolarizing current. Action potentials were observed in p15 mut and p7 wt IHCs, but not in p15 wt despite stronger current injection. 
Immunoreactivity for the pore-forming subunit KCNMA1 with the typical spot-like staining at the "neck" of IHCs (Pyott et al., 2004; Hafidi et al., 2005; Nemzou et al., 2006) was detected in organs of Corti of p15 wt mice (Fig. 21A, $n=3$ cochleae of 2 mice). Consistent with the lack of functional BK channels in the mutant IHCs we did not observe KCNMA1 immunoreactivity in organs of Corti from p15 $\mathrm{Pax}^{-/-}$mice (Fig. 21B, 3 cochleae of 2 mice). However, we found the typical spot-like KCNMA1 staining in p14-15 IHCs of TH-substituted Pax8 ${ }^{-/-}$mice (Fig. 21C, $n=2$ cochleae of 2 mice), lending further support for the TH-dependency of BK abundance in IHCs. Using quantitative RT-PCR we failed to detect significant differences between KCNMA1 mRNA levels in organs of Corti of p14-17 wt (100\% [95\% Cl: $75 \ldots 133 \%]$ ]) and p14-17 Pax8 $^{-/-}$(92\% [95\% Cl: 53...137\%]) mice (Fig. 22, $\mathrm{n}=24$ organs of Corti from 12 mice). Follow-up experiments with higher IHC specificity, including single IHC RT-PCR for KCNMA or in situ hybridization should be performed in the future. KCNMA1 mRNA abundance was TH-dependent in the cerebellum (Fig. 22).
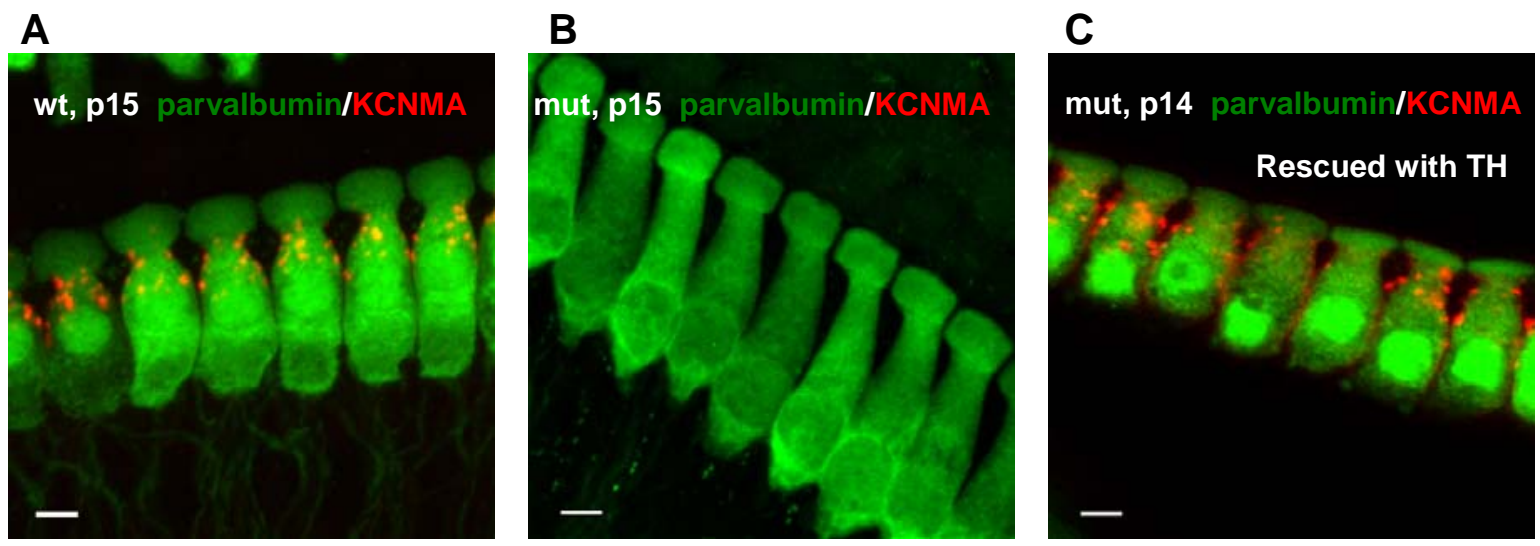

Fig. $21 \boldsymbol{A}-\boldsymbol{C}$ show representative projections of confocal sections obtained from organs of Corti of p15 WT $(\boldsymbol{A})$, mut $(\boldsymbol{B})$ and rescued mut $(\boldsymbol{C})$ mice after KCNMA1 (red) and parvalbumin (green) immunostaining: note spots of KCNMA1 immunofluorescence at the neck of wt and rescued mut IHCs but not in athyroid mut IHCs. 4\% PFA was used as fixative. Scale bars: $5 \mu \mathrm{m}$. 


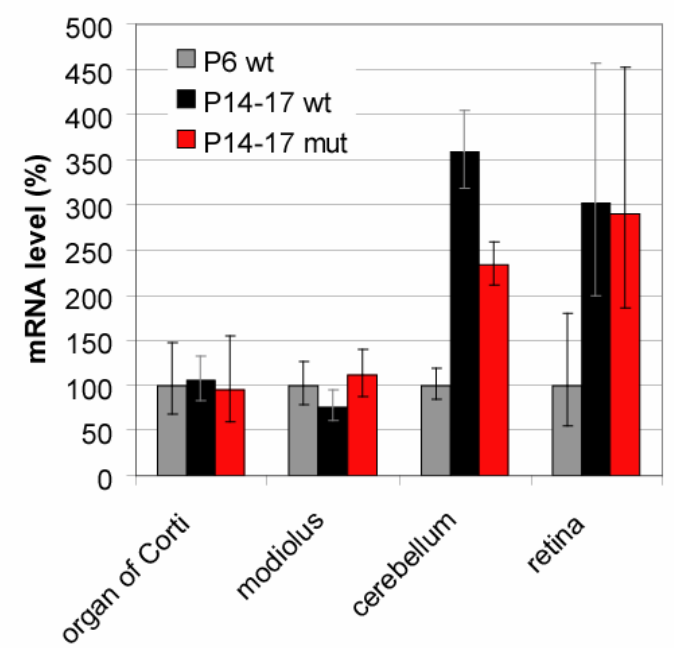

Fig. 22 Show relative amounts of KCNMA mRNA estimated by quantitative RTPCR. Total RNA was isolated from organ of Corti, modiolus, cerebellum and retina of $\mathrm{p} 6 \mathrm{Pax}^{+/+}$(grey), $\mathrm{p} 14-17 \mathrm{Pax}^{+/+}$(black) and $\mathrm{p} 14-17 \mathrm{Pax}^{-/-}$(red) mice $(n=12$ mice each). The expression of the target mRNAs was normalized first to that of TBP and then to the values obtained for corresponding mRNA and tissue of p6 $\mathrm{Pax}^{+/+}$mice. The data are represented as means from 4 independent experiments in which all samples were analyzed in triplicates (error bars indicate 95\% confidence intervals of the population estimate of mRNA abundance).

\section{Prolonged presence of efferent IHC synapses in Pax ${ }^{-/}$mice}

Current clamp recordings from $15 \mathrm{Pax}^{-/-} \mathrm{IHC}$ revealed small biphasic potentials (Fig. 23A) which closely resembled the previously described cholinergic postsynaptic potentials of immature IHCs (Glowatzki and Fuchs, 2000; Brandt et al., 2003; Katz et al., 2004). We then analyzed the efferent IHC innervation by immunohistochemistry for the efferent presynaptic marker synaptophysin (IHC are devoid of synaptophysin) and for small conductance $\mathrm{Ca}^{2+}$ activated $\mathrm{K}^{+}$channels (SK2) as postsynaptic efferent marker. In p15 $\mathrm{Pax}^{-{ }^{--}}$mice we readily observed juxtaposed synaptophysin and SK2 immunofluorescence spots indicative of efferent IHC synapses (Fig. 23B, 11.7 spots per IHC, $\mathrm{n}=20 \mathrm{IHCs}, 4$ cochleae of 4 mice). The same pattern was observed in p22 $\mathrm{Pax}^{-/-}$(Fig. 24) We observed a lower number of juxtaposed synaptophysin 
and SK2 immunofluorescence spots in p15 wt IHCs (Fig. 23C, 4.1 spots per IHC, 3 cochleae of 2 mice), which is consistent with the description of a developmental decline of efferent IHC innervation in wt rats and mice (Katz et al., 2004; Nemzou et al., 2006). While SK2 expression was robust in athyroid IHCs it was more variable in IHCs of wt organs of Corti ranging from a mosaic pattern (Fig. 23C) to a complete lack of SK2 staining (Fig. 23D). The synaptophysin staining remaining in mature wt organs of Corti after loss of IHC SK2 immunoreactivity most likely reflects efferent presynaptic terminals of the lateral olivocochlear bundle making synapses onto afferent fibers (Simmons, 2002; Nemzou et al., 2006). Vesiculated efferent terminals facing a postsynaptic density and its nearby synaptoplasmic cistern (Lioudyno et al., 2004) were much more frequently encountered in electron micrographs of mut p14$15 \mathrm{IHCs}$ (Fig. 23E) than in IHCs of WT littermates.

\section{Discussion}

In the present study we investigated the postnatal maturation of cochlear IHCs and their synapses in normal mice, athyroid $\mathrm{Pax}^{-/-}$mice and $\mathrm{TH}-$ rescued $\mathrm{Pax} 8^{-/-}$mice. We demonstrate that $\mathrm{TH}$ signaling is required for the normal molecular, morphological and functional maturation of IHC ribbon synapses. In athyroid mice, IHC action potential firing persisted up to the end of the second postnatal week and efferent innervation of IHCs by olivocochlear fibers was maintained up to the third postnatal week (Fig. 25 summarizes TH-dependent developmental changes of IHCs). Congenital hypothyroidism has been shown to impair multiple developmental processes within the inner ear offering much mechanistic explanation for hypothyroid 
deafness. The presynaptic dysfunction of IHCs in athyroid mice seems incompatible with coding of the temporal structure and graded intensity of sounds, even if cochlear amplification, transduction and other upstream processes were intact.
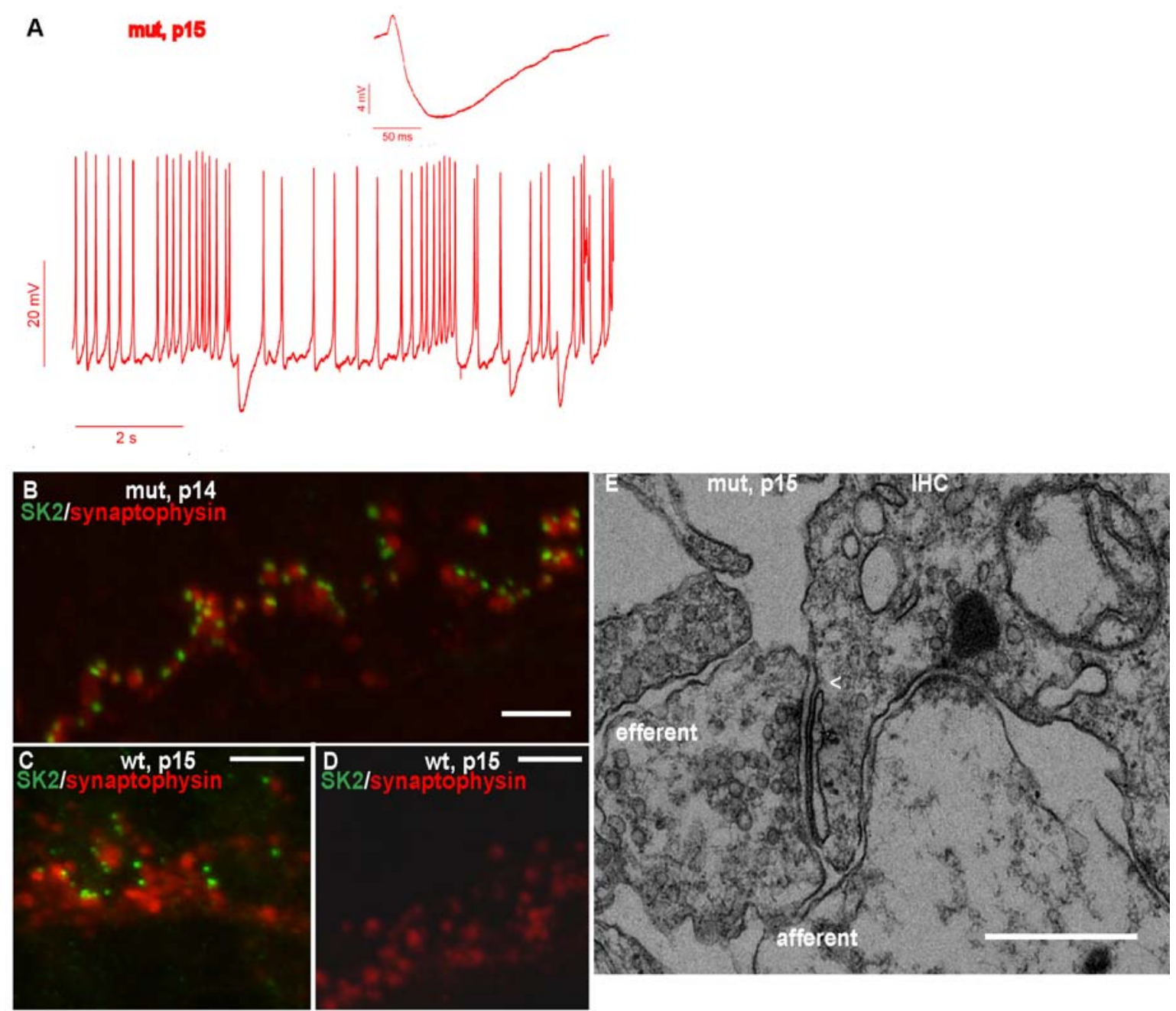

Fig.23 $A$ shows a membrane potential recording from a p15 $\mathrm{Pax}^{-1-}$ IHC displaying spontaneous action potentials and small biphasic potentials (see inset) characteristic for cholinergic postsynaptic potentials. B-D show representative projections of confocal sections obtained from organs of Corti of a p15 mut (B) and a p15 wt $(\boldsymbol{C}, \boldsymbol{D})$ mice after synaptophysin (red) and SK2 (green) immunostaining. $E$, representative electron micrograph showing the basal pole of a p15 mut IHC with an efferent synapse onto the IHC featuring the presynaptic terminal with synaptic vesicles and the characteristic postsynaptic cistern in the IHC (arrowheads). The IHC forms a ribbon synapse with an afferent fiber next to the efferent IHC synapse. Scale bars: $2 \mu \mathrm{m}$ for $\boldsymbol{B}-\mathbf{D}, 500 \mathrm{~nm}$ for $\boldsymbol{E}$ 


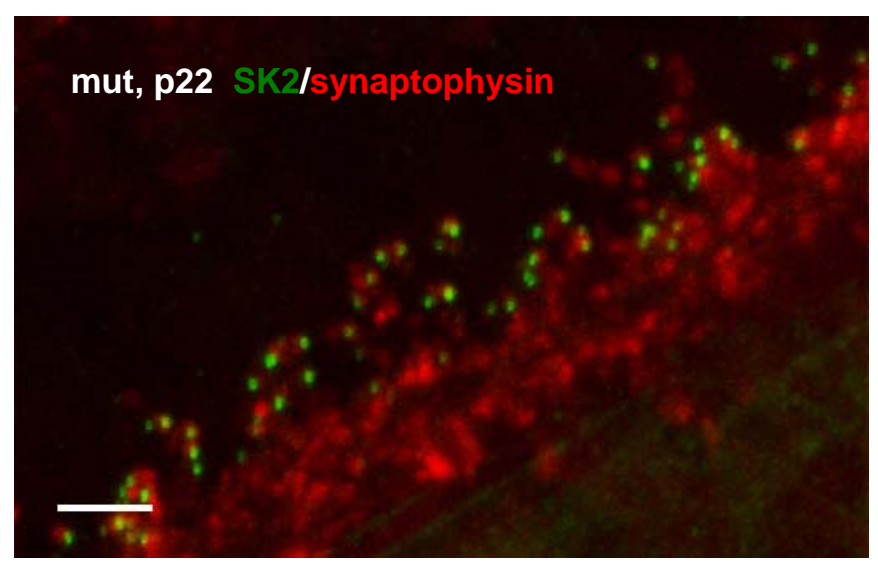

Fig. 24 Shows a representative projection of confocal sections obtained from the organ of Corti of a p22 mut after synaptophysin (red) and SK2 (green) immunostaining. Scale bar is $5 \mu \mathrm{m}$.

Ribbon synapses are formed but their maturation is retarded in IHCs of athyroid mice

Our morphological investigation of athyroid $\mathrm{Pax}^{-/-}$mice revealed that $\mathrm{IHC}$ ribbon synapses are formed despite congenital TH deficiency. However, the maturation of their molecular anatomy and physiology was impaired. Our quantitative PCR revealed that the mRNA levels for the SNAREs SNAP25 and synaptobrevin 1 in the organ of Corti increase during normal postnatal synaptic maturation in a $\mathrm{TH}$ dependent fashion. We take this as an indication for a developmental upregulation of SNAREs in IHCs, which is in line with a preliminary immunohistochemical report (Eybalin et al., 2001). This adds to previous work describing a developmental upregulation of cysteine string protein in IHCs (Eybalin et al., 2002), which serves as a presynaptic co-chaperone (Schmitz et al., 2006). The TH-dependent increase of mRNA abundance for the two SNAREs in the cerebellum is in line with previous reports of a developmental SNAP25 protein upregulation accompanying synaptogenesis (Mayanil and Knepper, 1993; Bark et al., 1995) and a TH 
dependence of cerebellar development (Vincent et al., 1982; Mayanil and Knepper, 1993; Hashimoto et al., 2001; Bernal, 2005).

Morphologically, IHCs of $\mathrm{TH}$-deficient organs of Corti continued to have large numbers of ribbons and immature synaptic contacts (e.g. showing several ribbons) at least up to $p 15$, when normally maturation and pruning have resulted in fewer and confined single ribbon synapses (Pujol et al., 1980; Shnerson et al., 1981; Sobkowicz et al., 1982; Pujol et al., 1997, this study). The IHCs of 2-week-old Pax8 mice were also functionally comparable to immature wt IHCs (see Fig. 25, table 2 and the below section), except for showing more sustained exocytosis. Normal maturation of ribbon synapse morphology and function could be restored upon $\mathrm{TH}-$ substitution, proving that the TH-deficiency was at the origin of our findings in the athyroid Pax8 ${ }^{-1}$ mice.

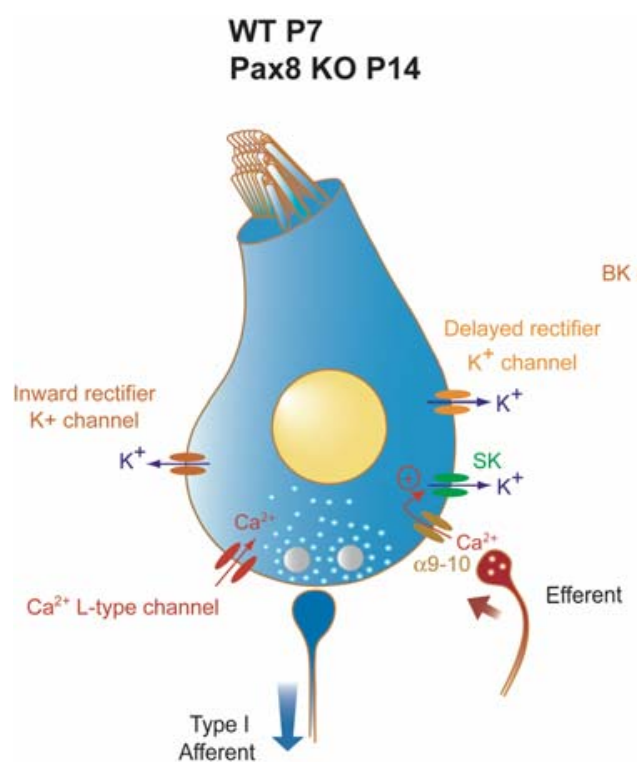

WT P14

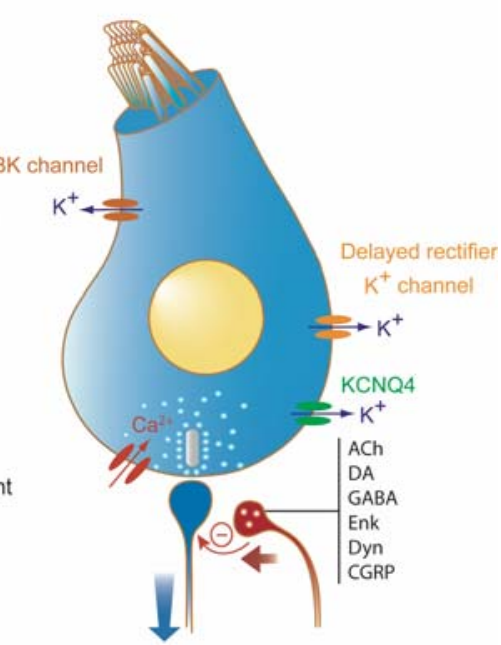

Fig. 25 Left: Sketches the immature IHC morphological and functional properties found in wt IHCs before the onset of hearing and in 2-week-old $\mathrm{Pax}^{-/-}$IHCS. Right: mature basolateral make-up of IHCs after the onset of hearing. Courtesy of Régis Nouvian. 
Towards deciphering the developmental improvement of stimulussecretion coupling in IHCS

The ribbon synapses of mature IHCs code sound with extraordinary temporal precision (Fuchs, 2005; Moser et al., 2006). Two of the mechanisms contributing to this capability - rapid but graded membrane potential responses to sensory input and efficient $\mathrm{Ca}^{2+}$ influx-exocytosis coupling - are lacking from immature wt as well as from p14-16 mice with impaired TH signaling (Kros et al., 1998; Rusch et al., 1998; Beutner and Moser, 2001, the present study).

First, their IHCs lack BK currents and hence their membrane potential cannot follow transduction with graded responses but fire $\mathrm{Ca}^{2+}$ action potentials instead. Large $\mathrm{Ca}^{2+}$ currents and the less hyperpolarized resting potential owing to the absence of $\mathrm{KCNQ}_{4}$ channels also contribute to the firing in two-week-old Pax8 ${ }^{-/-} \mathrm{IHCs}$. The lack of $\mathrm{IHC}$ BK currents of two-week-old athyroid Pax $8^{-/-}$mice is consistent with the previously described delayed $\mathrm{BK}$ acquisition in $\mathrm{IHCs}$ of $\mathrm{TH}$ receptor mouse mutants (Rusch et al., 1998; Rusch et al., 2001). We could not test for a potential later acquisition of $\mathrm{BK}$ channels as $\mathrm{Pax}^{-/-}$mice die before weaning (Mansouri et al., 1998). The absence of KCNMA1 immunoreactivity confirms our electrophysiological finding. However, our study cannot definitively tell which step towards the acquisition of functional BK channels by IHCs is promoted by $\mathrm{TH}$ (see below).

Second, more $\mathrm{Ca}^{2+}$ influx is required for the same amount of fast exocytosis in IHCs of immature wt as well as of $\mathrm{p} 14-15 \mathrm{Pax}^{-/-}$mice. Potential mechanisms include impaired priming of readily releasable vesicles for exocytosis and a less favorable positional arrangement of $\mathrm{Cav} 1.3 \mathrm{Ca}^{2+}$ channels and vesicular release sites. 
Developmental changes in the molecular composition of the exocytic machinery (see above) could well improve the vesicle's fusion competence and/or the active zone's topography. A lower expression of SNAP-25 and synaptobrevin 1 in immature wt and $\mathrm{Pax} \mathrm{8}^{-/-} \mathrm{IHC}$ could imply that vesicles have a lower probability of becoming primed (Sorensen et al., 2003; Borisovska et al., 2005). SNAP23 may then compete more successfully with SNAP25 for the formation of SNARE complexes in immature wt and two-week-old Pax8 $8^{-/-} \mathrm{IHC}$, resulting in reduced vesicle priming and exocytosis efficiency.

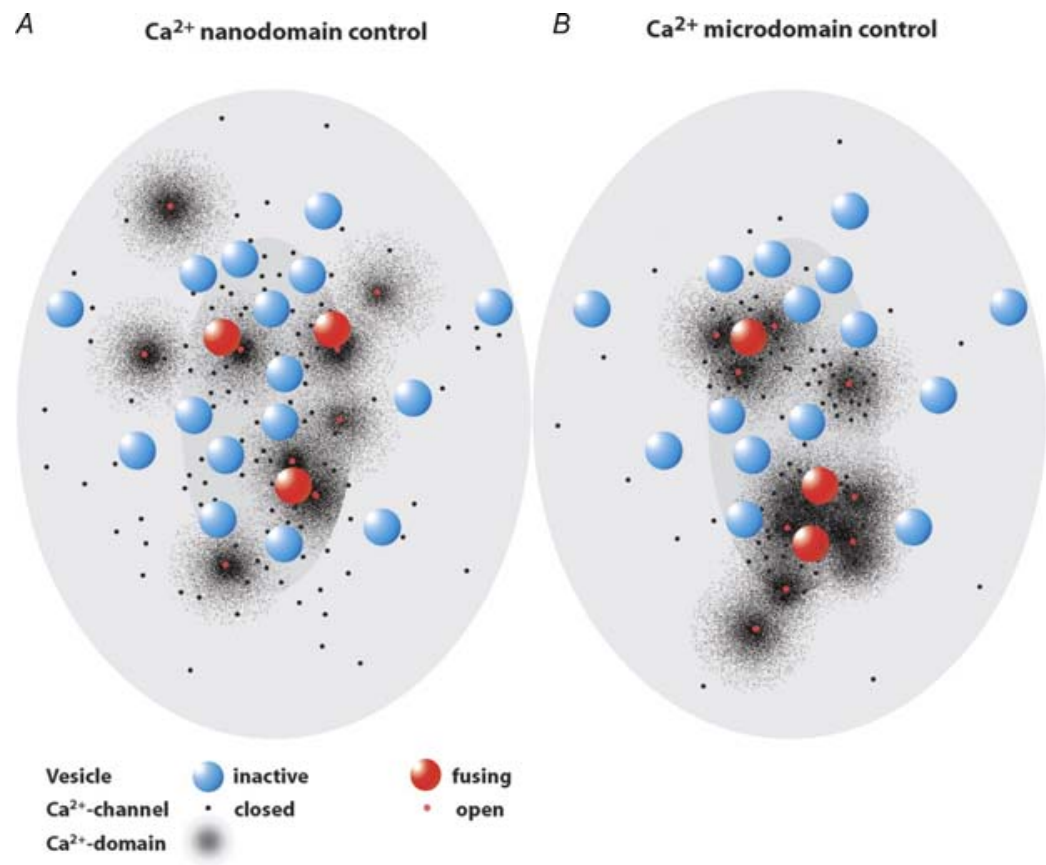

Fig. 26 Sketches the IHC active zones seen from the cytosolic site with the ribbon removed (central ellipse indicates the ribbon's projection) facing the postsynaptic density (outer ellipse). The figure illustrates two different $\mathrm{Ca}^{2+}$-channel-release site topographies, namely a nanodomain control of vesicle fusion $(\boldsymbol{A})$ and the scenario where microdomains govern vesicle's release $(\boldsymbol{B})$. (A) 80 channels were scattered pseudo-randomly at the active zone with a higher density underneath the ribbon and increased probability of being close to a synaptic vesicle. 9 channels are open (red) forming small $\mathrm{Ca}^{2+}$ domains, some of which control the fusion of vesicles under their influence. (B) most of the 80 channels are clustered in three groups, where overlapping $\mathrm{Ca}^{2+}$ domains control the fusion of vesicles (Brandt et al., 2005; see also review by Moser et al., 2006b). 
The efficiency of $\mathrm{Ca}^{2+}$ influx to trigger sustained exocytosis in two-week-old Pax8 ${ }^{-/-}$ IHCs (Fig. 14B) exceeded that of immature wt IHCs. This might argue that twoweek-old $\mathrm{Pax}^{-/-} \mathrm{IHC}$ have matured to some extent beyond what is normally achieved at the end of the first postnatal week.

In addition or alternatively, immature wt and $\mathrm{Pax}^{-{ }^{-}-} \mathrm{IHCs}$ may have not yet achieved the tight spatial coupling of vesicles to $\mathrm{Ca}^{2+}$ channels of mature IHCs, that gives rise to a "Ca ${ }^{2+}$ nanodomain" control of exocytosis ( see Fig. 26; Brandt et al., 2005).

Let us assume that the so far uncharacterized "intrinsic" $\mathrm{Ca}^{2+}$ cooperativity of exocytosis in immature $\mathrm{IHCs}$ was as high as estimated in mature $\mathrm{IHCs}$ by $\mathrm{Ca}^{2+}$ uncaging (4-5, Beutner et al., 2001). Then, we would expect their ("apparent") $\mathrm{Ca}^{2+}$ cooperativity during $\mathrm{Ca}^{2+}$ influx evoked by depolarizations of varying strength to approach the "intrinsic" $\mathrm{Ca}^{2+}$ cooperativity, if many channels cooperated to control a given vesicle's exocytosis at a immature active zone (" $\mathrm{Ca}^{2+}$ microdomain" control). Indeed, the "apparent" $\mathrm{Ca}^{2+}$ cooperativity of exocytosis was shown to be higher in immature than in mature IHCs, when manipulating $\mathrm{Ca}^{2+}$ influx by changing the strength of depolarization (Johnson et al., 2005). A developmental switch from " $\mathrm{Ca}^{2+}$ microdomain" to " $\mathrm{Ca}^{2+}$ nanodomain" control of exocytosis as suggested for $\mathrm{IHCs}$, has recently been indicated for the calyx of Held (Fedchyshyn and Wang, 2005).

\section{Regulation of postnatal IHC development}

Recently, insights into the regulation of postnatal hair cell development have been obtained from analyzing mouse mutants with impaired $\mathrm{TH}$ signaling (review in

Forrest et al., 2002; Brandt et al., 2007), deficiency for the Cav1.3 L-type Ca ${ }^{2+}$ 
channel (Brandt et al., 2003; Nemzou et al., 2006) and mutations of the transmembrane cochlear-expressed gene 1 (Tmc1, Marcotti et al., 2006). Besides showing various other inner ear defects, all these mutants share a prolonged immaturity of two or more aspects of IHC biology (Table 2). It is exciting to think about how the signaling pathways targeted in these different mutants converge to mediate normal development. However, to date an integrative view has yet to be established.

$\mathrm{TH}$ regulation of gene transcription is a well established mechanism and has been implicated in various neurodevelopmental processes (Bernal, 2005). TH binding to its nuclear receptors modulates their function as transcription factors (for review see Forrest et al., 2002). TH receptors bind to DNA regulatory elements (TH response elements, TRE) as homodimers or heterodimers with retinoid-X-receptors to regulate gene transcription. In outer hair cells of the cochlea, for example, it was shown that TH promotes expression of the motor protein Prestin through TH receptor beta TRE binding (Weber et al., 2002) and at the same time de-represses transcription of the Kcnq4 gene, as $\mathrm{TH}$-binding to $\mathrm{TH}$ receptor alpha dissociates it from its TRE. The latter mechanism may also be at work for the $\mathrm{TH}$ dependent expression of $\mathrm{KCNQ}_{4}$ channels during $\mathrm{IHC}$ development. We consider it possible that $\mathrm{TH}$, rather than acting on a TRE upstream of each individual affected gene, may trigger an entire transcriptional program, for example by interacting with other transcription factors, including activity dependent factors (Kim et al., 2005) or a $\mathrm{Ca}^{2+}$ channel-derived transcription factor (Gomez-Ospina et al., 2006). This could offer an explanation for common effects of TH deficiency and lack of Cav1.3 channels and consequently 
absent regenerative $\mathrm{Ca}^{2+}$ signaling in neonatal IHC (Table 2). Recently, the transcription factor MEF2 has been implicated in the regulation of CNS excitatory synapse number via activation through calcium-regulated sumoylation and thus it could serve to modulate activity-dependent synapse development and plasticity in the brain (Shalizi et al., 2006; Flavell et al., 2006). Whether MEF2 is controlled by TH or whether it is expressed in hair cells at all remains highly speculative, but such a mechanism could in principle be at play during hair cell's synaptic pruning. In addition, TH may promote hair cell differentiation by regulating expression of target proteins at steps downstream of transcription (Sampson et al., 2002). Such a mechanism may account for the lack of functional BK channels in IHCs of Pax ${ }^{-/-}$ mice, as, in contrast to our findings in Cav1.3 $3^{-/-}$mice (Nemzou et al., 2006), we failed to detect a reduction of KCNMA mRNA levels in their organs of Corti.

Interestingly, a role of $\mathrm{TH}$ in the regulation of the developmental redistribution of prestin in outer hair cells has recently been demonstrated (Weber et al., 2002). The putative trafficking protein Tmc1 is an attractive candidate for mediating posttranscriptional $\mathrm{TH}$ effects in IHC differentiation as IHCs of Tmc1- and hypothyroid mutants share a number of developmental defects (Table 2). Further experiments, including the investigation of Tmc1 expression in IHCs of hypothyroid mice, will be required, to further dissect the complex signaling driving postnatal IHC differentiation. 
Table 2: Comparison of developmental IHC defects in mutants with TH signaling defects in comparison to Cav1.3 $\mathrm{KO}$ and tmc1 mutants

The table compares the developmental abnormalities of hair cells and their synapses between hypothyroid mutants, tmc1 mutants and $\mathrm{Ca}_{\mathrm{v}} 1.3^{-/-}$mice. Common phenotypes are highlighted by grey frames.

References: 1, Rusch et al., 1998; 2, Rusch et al., 2001; 3, Bock and Steel, 1983; 4, Marcotti et al., 2006; 5, Brandt et al., 2003; 6, Nemzou et al., 2006

\begin{tabular}{|c|c|c|c|c|}
\hline & $\begin{array}{l}\text { Acquisition of BK } \\
\text { and } \mathrm{KCNQ}_{4} \\
\text { current }\end{array}$ & $\begin{array}{c}\text { Ribbon } \\
\text { synapse } \\
\text { morphology }\end{array}$ & $\begin{array}{l}\text { Ribbon } \\
\text { synapse } \\
\text { function } \\
\left(\mathrm{Ca}^{2+} \text { current and }\right. \\
\text { Exocytosis })\end{array}$ & $\begin{array}{l}\text { Efferent IHC } \\
\text { innervation }\end{array}$ \\
\hline $\begin{array}{l}\text { TH signaling } \\
\text { defect }\end{array}$ & $\begin{array}{l}\text { BK delayed and } \\
\text { reduced } \\
\text { BK and } \mathrm{KCNQ}_{4} \text { not } \\
\text { detectable up to } \\
\text { p15 in Pax8 KO }\end{array}$ & $\begin{array}{c}\text { retarded } \\
\text { synaptogenesis } \\
\text { in Pax8 KO }\end{array}$ & $\begin{array}{c}\text { late upregulation } \\
\text { and no maturation at } \\
\text { least up to p15 in } \\
\text { Pax8 KO }\end{array}$ & $\begin{array}{c}\text { maintained at } \\
\text { least up to p22 } \\
\text { in Pax8 KO }\end{array}$ \\
\hline Tmc1 defect ${ }^{3,4}$ & $\begin{array}{l}\mathrm{BK} \text { and } \mathrm{KCNQ}_{4} \text { not } \\
\text { detectable up to } \\
\text { p58 }\end{array}$ & $\begin{array}{l}\text { only few nerve } \\
\text { endings found } \\
\text { at p15 }\end{array}$ & $\begin{array}{l}\text { maintained } \\
\text { immature } \mathrm{Ca}^{2+} \\
\text { current and } \\
\text { exocytosis }\end{array}$ & not evaluated \\
\hline Cav1.3 deletion ${ }^{5,6}$ & $\begin{array}{l}\text { BK not detectable } \\
\text { up to up p35; } \\
\mathrm{KCNQ}_{4} \text { present }\end{array}$ & $\begin{array}{c}\text { normal } \\
\text { synaptogenesis, } \\
\text { secondary loss }\end{array}$ & $\begin{array}{l}\text { stimulus-secretion } \\
\text { coupling blocked; } \\
\text { normal exocytosis } \\
\text { upon } \mathrm{Ca}^{2+} \text { uncaging }\end{array}$ & $\begin{array}{l}\text { maintained at } \\
\text { least up to p45 }\end{array}$ \\
\hline
\end{tabular}




\section{References}

Ashmore J (2002) Biophysics of the cochlea - biomechanics and ion channelopathies. Br Med Bull. 63:59-72.

Bark IC, Hahn KM, Ryabinin AE, Wilson MC (1995) Differential expression of SNAP25 protein isoforms during divergent vesicle fusion events of neural development. Proc Natl Acad Sci U S A 92:1510-1514.

Barroso I, Benito B, Garci-Jimenez C, Hernandez A, Obregon MJ, Santisteban P (1999) Norepinephrine, tri-iodothyronine and insulin upregulate glyceraldehyde-3phosphate dehydrogenase mRNA during Brown adipocyte differentiation. Eur J Endocrinol 141:169-179.

Bautista DM, Jordt SE, Nikai T, Tsuruda PR, Read AJ, Poblete J, Yamoah EN, Basbaum Al, Julius D. (2006) TRPA1 mediates the inflammatory actions of environmental irritants and proalgesic agents. Cell. 124(6):1269-82.

Belyantseva IA, Boger ET, Naz S, Frolenkov GI, Sellers JR, Ahmed ZM, Griffith AJ, Friedman TB. (2005) Myosin-XVa is required for tip localization of whirlin and differential elongation of hair-cell stereocilia. Nat Cell Biol. (2):148-56.

Bernal J (2005) Thyroid hormones and brain development. Vitam Horm 71:95-122. Beutner D, Moser T (2001) The presynaptic function of mouse cochlear inner hair cells during development of hearing. J Neurosci 21:4593-4599.

Beutner D, Voets T, Neher E, Moser T (2001) Calcium dependence of exocytosis and endocytosis at the cochlear inner hair cell afferent synapse. Neuron 29:681-690.

Bock GR, Steel KP (1983) Inner ear pathology in the deafness mutant mouse. Acta Otolaryngol 96:39-47.

Borisovska M, Zhao Y, Tsytsyura Y, Glyvuk N, Takamori S, Matti U, Rettig J, Sudhof T, Bruns D (2005) v-SNAREs control exocytosis of vesicles from priming to fusion. Embo J 24:2114-2126.

Bradley DJ, Towle HC, Young WS 3rd. (1994) Alpha and beta thyroid hormone receptor (TR) gene expression during auditory neurogenesis: evidence for TR isoform-specific transcriptional regulation in vivo. Proc Natl Acad Sci U S A. 91(2):439-43. 
Brandt A, Striessnig J, Moser T (2003) CaV1.3 channels are essential for development and presynaptic activity of cochlear inner hair cells. J Neurosci 23:10832-10840.

Brandt A, Khimich D, Moser T (2005) Few CaV1.3 channels regulate the exocytosis of a synaptic vesicle at the hair cell ribbon synapse. J Neurosci 25:11577-11585.

Brandt N, Kuhn S, Braig C, Münkner S, Winter H, Blin N, Knipper M, Engel J (2007) Thyroid hormone deficiency affects postnatal spiking activity and expression of Ca2+ and $\mathrm{K}+$ channels in rodent inner hair cells. J Neurosci, in press.

Brownell WE, Bader CR, Bertrand D, de Ribaupierre Y. (1985) Evoked mechanical responses of isolated cochlear outer hair cells. Science, 227(4683):194-6.

Bruce LL, Christensen MA, Warr WB. (2000) Postnatal development of efferent synapses in the rat cochlea. J Comp Neurol. 423(3):532-48.

Bryant J, Goodyear RJ, Richardson GP (2002) Sensory organ development in the inner ear: molecular and cellular mechanisms. Br Med Bull 63:39-57.

Cabelli RJ, Hohn A, Shatz CJ. (1995) Inhibition of ocular dominance column formation by infusion of NT-4/5 or BDNF. Science. 267(5204):1662-6.

Campos-Barros A, Amma LL, Faris JS, Shailam R, Kelley MW, Forrest D. (2000) Type 2 iodothyronine deiodinase expression in the cochlea before the onset of hearing.Proc Natl Acad Sci U S A. 97(3):1287-92.

Chan DK, Hudspeth AJ. (2005) Ca2+ current-driven nonlinear amplification by the mammalian cochlea in vitro. Nat Neurosci. 8(2):149-55.

Christ S, Biebel UW, Hoidis S, Friedrichsen S, Bauer K, Smolders JW (2004) Hearing loss in athyroid pax8 knockout mice and effects of thyroxine substitution. Audiol Neurootol 9:88-106.

Corey DP, Garcia-Anoveros J, Holt JR, Kwan KY, Lin SY, Vollrath MA, Amalfitano A, Cheung EL, Derfler BH, Duggan A, Geleoc GS, Gray PA, Hoffman MP, Rehm HL, Tamasauskas D, Zhang DS. (2004) TRPA1 is a candidate for the mechanosensitive transduction channel of vertebrate hair cells. Nature. 2004 432(7018):723-30.

Denk W, Holt JR, Shepherd GM, Corey DP. (1995) Calcium imaging of single stereocilia in hair cells: localization of transduction channels at both ends of tip links. Neuron. (6):1311-21.

Deol MS (1973a) Congenital deafness and hypothyroidism. Lancet 2:105-106. 
Deol MS (1973b) An experimental approach to the understanding and treatment of hereditary syndromes with congenital deafness and hypothyroidism. J Med Genet 10:235-242.

Dodge FA Jr, Rahamimoff $R$ (1967) Co-operative action of calcium ions in transmitter release at the neuromuscular junction. J Physiol. 193(2):419-32.

Echteler SM. (1992) Developmental segregation in the afferent projections to mammalian auditory hair cells. Proc Natl Acad Sci U S A. 89(14):6324-7.

Edmonds BW, Gregory FD, Schweizer FE. (2004) Evidence that fast exocytosis can be predominantly mediated by vesicles not docked at active zones in frog saccular hair cells. J Physiol. 560; 439-50.

Edmonds B, Reyes R, Schwaller B \& Roberts WM (2000) Calretinin modifies presynaptic calcium signaling in frog saccular hair cells. Nature Neuroscience 3,8 786-790.

Ehret G (1985) Behavioural studies on auditory development in mammals in relation to higher nervous system functioning. Acta Otolaryngol Suppl 421:31-40.

Elgoyhen AB, Johnson DS, Boulter J, Vetter DE, Heinemann S. (1994) Alpha 9: an acetylcholine receptor with novel pharmacological properties expressed in rat cochlear hair cells. Cell. 1994 79(4):705-15.

Elgoyhen AB, Vetter DE, Katz E, Rothlin CV, Heinemann SF, Boulter J. (2001) alpha10: a determinant of nicotinic cholinergic receptor function in mammalian vestibular and cochlear mechanosensory hair cells. Proc Natl Acad Sci U S A. 98(6):3501-6.

Eybalin M, Renard N, Aure F, Safieddine S (2002) Cysteine-string protein in inner hair cells of the organ of Corti: synaptic expression and upregulation at the onset of hearing. Eur J Neurosci 15:1409-1420.

Fedchyshyn MJ, Wang LY (2005) Developmental transformation of the release modality at the calyx of held synapse. J Neurosci 25:4131-4140.

Felmy F, Schneggenburger R (2004) Developmental expression of the Ca2+-binding proteins calretinin and parvalbumin at the calyx of held of rats and mice. Eur $\mathrm{J}$ Neurosci 20:1473-1482.

Fettiplace R, Hackney CM. (2006) The sensory and motor roles of auditory hair cells. Nat Rev Neurosci. 7(1):19-29.

Flavell SW, Cowan CW, Kim TK, Greer PL, Lin Y, Paradis S, Griffith EC, Hu LS, Chen C, Greenberg ME. (2006) Activity-dependent regulation of MEF2 transcription factors suppresses excitatory synapse number. Science. 311(5763):1008-12. 
Forrest D, Reh TA, Rusch A (2002) Neurodevelopmental control by thyroid hormone receptors. Curr Opin Neurobiol 12:49-56.

Forrest D, Erway LC, Ng L, Altschuler R, Curran T. (1996) Thyroid hormone receptor beta is essential for development of auditory function. Nat Genet. 13(3):354-7.

Forti L, Bossi M, Bergamaschi A, Villa A, Malgaroli A. (1997) Loose-patch recordings of single quanta at individual hippocampal synapses. Nature. 1997 388(6645):874-8.

Fuchs PA (2005) Time and intensity coding at the hair cell's ribbon synapse. J Physiol.

Furukawa T, Matsuura S. (1978) Adaptive rundown of excitatory post-synaptic potentials at synapses between hair cells and eight nerve fibres in the goldfish. 276:193-209.

Gillespie PG, Walker RG. (2001) Molecular basis of mechanosensory transduction. Nature. 413(6852):194-202.

Glorieux J, Dussault JH, Letarte J, Guyda H, Morissette J (1983) Preliminary results on the mental development of hypothyroid infants detected by the Quebec Screening Program. J Pediatr 102:19-22.

Glowatzki E, Fuchs PA (2000) Cholinergic synaptic inhibition of inner hair cells in the neonatal mammalian cochlea. Science 288:2366-2368.

Glowatzki E, Fuchs PA (2002) Transmitter release at the hair cell ribbon synapse. Nat Neurosci 5:147-154.

Gomez-Ospina N, Tsuruta F, Barreto-Chang O, Hu L, Dolmetsch R (2006) The C terminus of the L-type voltage-gated calcium channel $\mathrm{Ca}(\mathrm{V}) 1.2$ encodes a transcription factor. Cell 127:591-606.

Griesinger CB, Richards CD, Ashmore JF(2005) Fast vesicle replenishment allows indefatigable signalling at the first auditory synapse.Nature. 435(7039):212-5.

Hackney CM, Mahendrasingam P, Penn A, Fettiplace R (2005) The concentrations of calcium buffering proteins in mammalian cochlear hair cells. J Neurosci. 25(34):7867-75.

Hafidi A, Beurg M, Dulon D (2005) Localization and developmental expression of BK channels in mammalian cochlear hair cells. Neuroscience 130:475-484. 
Hashimoto K, Curty FH, Borges PP, Lee CE, Abel ED, Elmquist JK, Cohen RN, Wondisford FE (2001) An unliganded thyroid hormone receptor causes severe neurological dysfunction. Proc Natl Acad Sci U S A 98:3998-4003.

Heller S, Bell AM, Denis CS, Choe Y \& Hudspeth AJ (2002) Parvalbumin 3 is an abundant $\mathrm{Ca} 2+$ buffer in hair cells. Journal of the Association for Research in Otolaryngology 3:488-498.

Herlitze S, Xie M, Han J, Hummer A, Melnik-Martinez KV, Moreno RL, Mark MD (2003) Targeting mechanisms of high voltage-activated Ca2+ channels. J Bioenerg Biomembr 35:621-637.

Holt JR, Gillespie SK, Provance DW, Shah K, Shokat KM, Corey DP, Mercer JA, Gillespie PG. (2002) A chemical-genetic strategy implicates myosin-1c in adaptation by hair cells. Cell. 108(3):371-81.

Hudspeth AJ (1997) How hearing happens. Neuron 19(5):947-50.

Johnson SL, Marcotti W, Kros CJ (2005) Increase in efficiency and reduction in $\mathrm{Ca} 2+$ dependence of exocytosis during development of mouse inner hair cells. J Physiol 563:177-191.

Kachar B, Parakkal M, Kurc M, Zhao Y, Gillespie PG (2000) High-resolution structure of hair-cell tip links. Proc Natl Acad Sci U S A. 97(24):13336-41.

Kandel E (2001) Principles of Neural Science. ch.30, pp.590-612. $4^{\text {th }}$ ed. McGrawHill.

Katz E, Elgoyhen AB, Gomez-Casati ME, Knipper M, Vetter DE, Fuchs PA, Glowatzki E (2004) Developmental regulation of nicotinic synapses on cochlear inner hair cells. J Neurosci 24:7814-7820.

Katz LC, Shatz CJ. (1996) Synaptic activity and the construction of cortical circuits. Science. 274(5290):1133-8.

Keen EC, Hudspeth AJ (2006) Transfer characteristics of the hair cell's afferent synapse. Proc Natl Acad Sci U S A. 103(14):5537-42.

Kennedy HJ, Crawford AC, Fettiplace R. (2005) Force generation by mammalian hair bundles supports a role in cochlear amplification.Nature. 433(7028):880-3.

Kennedy HJ, Evans MG, Crawford AC, Fettiplace R. (2006) Depolarization of cochlear outer hair cells evokes active hair bundle motion by two mechanisms. J Neurosci. 26(10):2757-66. 
Khimich D, Nouvian R, Pujol R, Tom Dieck S, Egner A, Gundelfinger ED, Moser T (2005) Hair cell synaptic ribbons are essential for synchronous auditory signalling. Nature 434:889-894.

Kiang NY, Rho JM, Northrop CC, Liberman MC, Ryugo DK. (1982) Hair-cell innervation by spiral ganglion cells in adult cats. Science. 217(4555):175-7.

Kim TG, Jung J, Mysliwiec MR, Kang S, Lee Y (2005) Jumonji represses alphacardiac myosin heavy chain expression via inhibiting MEF2 activity. Biochem Biophys Res Commun 329:544-553.

Knipper M, Bandtlow C, Gestwa L, Kopschall I, Rohbock K, Wiechers B, Zenner HP, Zimmermann U (1998) Thyroid hormone affects Schwann cell and oligodendrocyte gene expression at the glial transition zone of the VIIlth nerve prior to cochlea function. Development 125:3709-3718.

Knipper M, Zinn C, Maier H, Praetorius M, Rohbock K, Kopschall I, Zimmermann U. (2000) Thyroid hormone deficiency before the onset of hearing causes irreversible damage to peripheral and central auditory systems. J Neurophysiol. 83(5):3101-12.

Konishi M. Coding of auditory space. (2003) Annu Rev Neurosci. 26:31-55.

Kopp P (2002) Perspective: genetic defects in the etiology of congenital hypothyroidism. Endocrinology 143:2019-2024.

Kros CJ, Crawford AC (1990) Potassium currents in inner hair cells isolated from the guinea-pig cochlea. J Physiol 421:263-291.

Kros CJ (1996) "Physiology of mammalian cochlear hair cells" in The Cochlea, Dallos P (ed), Springer Verlag NY.

Kros CJ, Ruppersberg JP, Rusch A (1998) Expression of a potassium current in inner hair cells during development of hearing in mice. Nature 394:281-284.

Langer P, Grunder S, Rusch A (2003) Expression of Ca2+-activated BK channel mRNA and its splice variants in the rat cochlea. J Comp Neurol 455:198-209.

LeMasurier M, Gillespie PG. (2005) Hair-cell mechanotransduction and cochlear amplification.Neuron. 48(3):403-15.

Lenoir M, Shnerson A, Pujol R (1980) Cochlear receptor development in the rat with emphasis on synaptogenesis. Anat Embryol (Berl). 160(3):253-62.

Lenzi D, von Gersdorff H (2001) Structure suggests function: the case for synaptic ribbons as exocytotic nanomachines. Bioessays. (9):831-40. 
Li D, Henley CM, O'Malley BW, Jr. (1999) Distortion product otoacoustic emissions and outer hair cell defects in the hyt/hyt mutant mouse. Hear Res 138:65-72.

Liberman MC (1982) Single-neuron labeling in the cat auditory nerve. Science. 216(4551):1239-41.

Liberman MC, Gao J, He DZ, Wu X, Jia S, Zuo J. (2002) Prestin is required for electromotility of the outer hair cell and for the cochlear amplifier. Nature. 419(6904):300-4.

Liberman MC, O'Grady DF, Dodds LW, McGee J, Walsh EJ. (2000) Afferent innervation of outer and inner hair cells is normal in neonatally de-efferented cats. J Comp Neurol. 2000 423(1):132-9.

Lindau M, Neher E (1988) Patch-clamp techniques for time-resolved capacitance measurements in single cells. Pflügers Arch 411:137-146.

Lioudyno M, Hiel H, Kong JH, Katz E, Waldman E, Parameshwaran-lyer S, Glowatzki E, Fuchs PA (2004) A "synaptoplasmic cistern" mediates rapid inhibition of cochlear hair cells. J Neurosci 24:11160-11164.

Macchia PE (2000) Recent advances in understanding the molecular basis of primary congenital hypothyroidism. Mol Med Today 6:36-42.

Maison SF, Luebke AE, Liberman MC, Zuo J. (2002) Efferent protection from acoustic injury is mediated via alpha9 nicotinic acetylcholine receptors on outer hair cells. J Neurosci. 22(24):10838-46.

Mansouri A, Chowdhury K, Gruss P (1998) Follicular cells of the thyroid gland require Pax8 gene function. Nat Genet 19:87-90.

Mansouri A, Hallonet M, Gruss P. (1996) Pax genes and their roles in cell differentiation and development. Curr Opin Cell Biol. 8(6):851-7.

Marcotti W, Erven A, Johnson SL, Steel KP, Kros CJ (2006) Tmc1 is necessary for normal functional maturation and survival of inner and outer hair cells in the mouse cochlea. J Physiol 574:677-698.

Mayanil CS, Knepper PA (1993) Synaptic vesicle and synaptic membrane glycoproteins during pre- and postnatal development of mouse cerebral cortex, cerebellum and spinal cord. Dev Neurosci 15:133-145.

Mikaelian D, Ruben RJ (1965) Development of hearing in the nomal CBA-J mouse. Acta Otolaryngol 59:451-461. 
Moser T, Beutner D (2000) Kinetics of exocytosis and endocytosis at the cochlear inner hair cell afferent synapse of the mouse. Proc Natl Acad Sci U S A 97:883-888.

Moser T, Neef A, Khimich D (2006) Mechanisms underlying the temporal precision of sound coding at the inner hair cell ribbon synapse. J Physiol 576:55-62.

Moser T, Brandt A, Lysakowski A. (2006) Hair cell ribbon synapses. Cell Tissue Res. 326(2):347-59.

Nägerl UV, Novo D, Mody I \& Vergara JL (2000) Binding kinetics of calbindin-D28k determined by flash photolysis of caged $\mathrm{Ca2+}$. Biophysical Journal 79, 6: 30093018.

Nemzou RM, Bulankina AV, Khimich D, Giese A, Moser T (2006) Synaptic organization in CaV1.3 Ca2+ channel deficient cochlear hair cells. Neuroscience 141:1849-1860.

Ng L, Goodyear RJ, Woods CA, Schneider MJ, Diamond E, Richardson GP, Kelley MW, Germain DL, Galton VA, Forrest D (2004) Hearing loss and retarded cochlear development in mice lacking type 2 iodothyronine deiodinase. Proc Natl Acad Sci U S A 101:3474-3479.

Nouvian R, Beutner D, Parsons TD, Moser T (2006) Structure and function of the hair cell ribbon synapse. J Membr Biol 209:153-165.

O'Hagan R, Chalfie M, Goodman MB. (2005) The MEC-4 DEG/ENaC channel of Caenorhabditis elegans touch receptor neurons transduces mechanical signals. Nat Neurosci. (1):43-50.

Oliver D, Knipper M, Derst C, Fakler B (2003) Resting potential and submembrane calcium concentration of inner hair cells in the isolated mouse cochlea are set by KCNQ-type potassium channels. J Neurosci 23:2141-2149.

Oliver D, Taberner AM, Thurm H, Sausbier M, Arntz C, Ruth P, Fakler B, Liberman MC (2006) The role of BKCa channels in electrical signal encoding in the mammalian auditory periphery. J Neurosci 26:6181-6189.

Oliver D, He DZ, Klocker N, Ludwig J, Schulte U, Waldegger S, Ruppersberg JP, Dallos P, Fakler B. (2001) Intracellular anions as the voltage sensor of prestin, the outer hair cell motor protein. Science. 292(5525):2340-3.

Oliver D, Klocker N, Schuck J, Baukrowitz T, Ruppersberg JP, Fakler B. (2000) Gating of $\mathrm{Ca} 2+-$ activated $\mathrm{K}+$ channels controls fast inhibitory synaptic transmission at auditory outer hair cells. Neuron. 26(3):595-601. 
Pack AK \& Slepecky NB (1995) Cytoskeletal and calcium-binding proteins in the mammalian organ of Corti: cell type-specific proteins displaying longitudinal and radial gradients. Hearing Research 91:119-135.

Palmer AR, Russell IJ (1986) Phase-locking in the cochlear nerve of the guinea-pig and its relation to the receptor potential of inner hair-cells. Hearing Research 24(1):1-15.

Platzer J, Engel J, Schrott-Fischer A, Stephan K, Bova S, Chen H, Zheng H, Striessnig J (2000) Congenital deafness and sinoatrial node dysfunction in mice lacking class D L-type Ca2+ channels. Cell 102:89-97.

Poddar R, Paul S, Chaudhury S, Sarkar PK (1996) Regulation of actin and tubulin gene expression by thyroid hormone during rat brain development. Brain Res Mol Brain Res 35:111-118.

Puel JL (1995) Chemical synaptic transmission in the cochlea. Prog Neurobiol. 47(6):449-76. Review.

Pujol R, Carlier E, Lenoir M (1980) Ontogenetic approach to inner and outer hair cell function. Hear Res 2:423-430.

Pujol R, Lavigne-Rebillard M, Lenoir M (1997) Development of Sensory and Neural Structures in the Mammalian Cochlea. In: Development of the auditory system (Rubel EW, Popper AN, Fay RR, eds), pp 146-192. New York: Springer.

Pujol R, Carlier E. (1982) Cochlear synaptogenesis after sectioning the efferent bundle. Brain Res. 255(1):151-4.

Pyott SJ, Glowatzki E, Trimmer JS, Aldrich RW (2004) Extrasynaptic localization of inactivating calcium-activated potassium channels in mouse inner hair cells. J Neurosci 24:9469-9474.

Ravichandran V, Chawla A, Roche PA (1996) Identification of a novel syntaxin- and synaptobrevin/VAMP-binding protein, SNAP-23, expressed in non-neuronal tissues. J Biol Chem 271:13300-13303.

Ricci AJ, Crawford AC, Fettiplace R. (2003) Tonotopic variation in the conductance of the hair cell mechanotransducer channel. Neuron. 2003 40(5):983-90.

Ricci AJ, Kennedy HJ, Crawford AC, Fettiplace R. (2005) The transduction channel filter in auditory hair cells.J Neurosci. 25(34):7831-9.

Ricci AJ, Crawford AC, Fettiplace R. (2002) Mechanisms of active hair bundle motion in auditory hair cells. J Neurosci. 22(1):44-52. 
Rose SR, Brown RS, Foley T, Kaplowitz PB, Kaye Cl, Sundararajan S, Varma SK (2006) Update of newborn screening and therapy for congenital hypothyroidism. Pediatrics 117:2290-2303.

Roux I, Safieddine S, Nouvian R, Grati M, Simmler MC, Perfettini I, Le Gall M, Rostaing P, Hamard G, Hardelin JP, Triller A, Avan P, Moser T, Petit C (2006) Otoferlin, defective in DFNB9 deafness, is essential for the Ca2+-triggered synaptic exocytosis at the auditory hair cell ribbon synapse. Cell 127 (2):277-89.

Rusch A, Erway LC, Oliver D, Vennstrom B, Forrest D (1998) Thyroid hormone receptor beta-dependent expression of a potassium conductance in inner hair cells at the onset of hearing. Proc Natl Acad Sci U S A 95:15758-15762.

Rusch A, Ng L, Goodyear R, Oliver D, Lisoukov I, Vennstrom B, Richardson G, Kelley MW, Forrest D (2001) Retardation of cochlear maturation and impaired hair cell function caused by deletion of all known thyroid hormone receptors. J Neurosci 21:9792-9800.

Russell IJ, Sellick PM. (1978) Intracellular studies of hair cells in the mammalian cochlea.J Physiol. 284:261-90.

Rutherford MA, Roberts WM. (2006) Frequency selectivity of synaptic exocytosis in frog saccular hair cells. Proc Natl Acad Sci U S A. 103(8):2898-903.

Ruttiger L, Sausbier M, Zimmermann U, Winter H, Braig C, Engel J, Knirsch M, Arntz C, Langer P, Hirt B, Muller M, Kopschall I, Pfister M, Munkner S, Rohbock K, Pfaff I, Rusch A, Ruth P, Knipper M. (2004) Deletion of the Ca2+-activated potassium (BK) alpha-subunit but not the BKbeta1-subunit leads to progressive hearing loss. Proc Natl Acad Sci U S A. 101(35):12922-7.

Ryan TA, Reuter H, Smith SJ. (1997) Optical detection of a quantal presynaptic membrane turnover. Nature. 388(6641):478-82.

Sabatini BL, Regehr WG (1999) Timing of synaptic transmission. Annu Rev Physiol. 61:521-42.

Safieddine S, Wenthold RJ (1999) SNARE complex at the ribbon synapses of cochlear hair cells: analysis of synaptic vesicle- and synaptic membrane-associated proteins. Eur J Neurosci 11:803-812.

Sampson D, Pickard M, Evans I, Leonard A, Sinha A, Ekins R (2002) Thyroid hormone regulates the expression of alpha-internexin in neurons in culture. Neuroreport 13:273-276. 
Schmitz F, Konigstorfer A, Sudhof TC (2000) RIBEYE, a component of synaptic ribbons: a protein's journey through evolution provides insight into synaptic ribbon function. Neuron 28:857-872.

Schmitz F, Tabares L, Khimich D, Strenzke N, de la Villa-Polo P, Castellano-Munoz M, Bulankina A, Moser T, Fernandez-Chacon R, Sudhof TC (2006) CSP\{alpha\}deficiency causes massive and rapid photoreceptor degeneration. Proc Natl Acad Sci U S A.

Schnee ME, Lawton DM, Furness DN, Benke TA, Ricci AJ. (2005) Auditory hair cellafferent fiber synapses are specialized to operate at their best frequencies. Neuron. 47(2):243-54.

Schneider ME, Belyantseva IA, Azevedo RB, Kachar B. (2002) Rapid renewal of auditory hair bundles. Nature. 418(6900):837-8.

Schwaller B, Durussel I, Jermann D, Herrmann B \& Cox JA (1997) Comparison of the Ca2+-binding Properties of Human Recombinant Calretinin-22k and Calretinin Journal of Biological Chemistry 272, 47:29663-29671.

Shalizi A, Gaudilliere B, Yuan Z, Stegmuller J, Shirogane T, Ge Q, Tan Y, Schulman B, Harper JW, Bonni A. (2006) A calcium-regulated MEF2 sumoylation switch controls postsynaptic differentiation. Science. 311(5763):1012-7.

Shepherd G (1994) Neurobiology. Oxford University Press, Oxford, UK.

Shnerson A, Devigne C, Pujol R (1981) Age-related changes in the C57BL/6J mouse cochlea. II. Ultrastructural findings. Brain Res 254:77-88.

Siegel JH. (1992) Spontaneous synaptic potentials from afferent terminals in the guinea pig cochlea. Hear Res. 59(1):85-92.

Siemens J, Lillo C, Dumont RA, Reynolds A, Williams DS, Gillespie PG, Muller U. (2004) Cadherin 23 is a component of the tip link in hair-cell stereocilia. Nature. 428(6986):950-5.

Simmons DD (2002) Development of the inner ear efferent system across vertebrate species. J Neurobiol 53:228-250.

Simmons DD, Mansdorf NB, Kim JH. (1996) Olivocochlear innervation of inner and outer hair cells during postnatal maturation: evidence for a waiting period. J Comp Neurol. 370(4):551-62.

Slepecky NB \& Ulfendahl M (1993) Evidence for calcium-binding proteins and calcium-dependent regulatory proteins in sensory cells of the organ of Corti. Hearing Research 70:73-84. 
Sobkowicz HM, Rose JE, Scott GE, Slapnick SM (1982) Ribbon synapses in the developing intact and cultured organ of Corti in the mouse. J Neurosci 2:942-957.

Sollner C, Rauch GJ, Siemens J, Geisler R, Schuster SC, Muller U, Nicolson T; Tubingen 2000 Screen Consortium. (2004) Mutations in cadherin 23 affect tip links in zebrafish sensory hair cells. Nature. 428(6986):955-9.

Sorensen JB, Nagy G, Varoqueaux F, Nehring RB, Brose N, Wilson MC, Neher E (2003) Differential control of the releasable vesicle pools by SNAP-25 splice variants and SNAP-23. Cell 114:75-86.

Spassova MA, Avissar M, Furman AC, Crumling MA, Saunders JC, Parsons TD. (2004) Evidence that rapid vesicle replenishment of the synaptic ribbon mediates recovery from short-term adaptation at the hair cell afferent synapse.J Assoc Res Otolaryngol. (4):376-90.

Steel KP (1999) Perspectives: biomedicine. The benefits of recycling. Science 285(5432):1363-4.

Stuart ET, Kioussi C, Gruss P. (1994) Mammalian Pax genes. Annu Rev Genet. 28:219-36.

Takeda K, Sakurai A, DeGroot LJ, Refetoff S. (1992) Recessive inheritance of thyroid hormone resistance caused by complete deletion of the protein-coding region of the thyroid hormone receptor-beta gene. J Clin Endocrinol Metab. 74(1):49-55.

Takeda K, Balzano S, Sakurai A, DeGroot LJ, Refetoff S. (1991) Screening of nineteen unrelated families with generalized resistance to thyroid hormone for known point mutations in the thyroid hormone receptor beta gene and the detection of a new mutation. J Clin Invest. 87(2):496-502.

Thoreson WB, Rabl K, Townes-Anderson E, Heidelberger R. (2004) A highly Ca2+sensitive pool of vesicles contributes to linearity at the rod photoreceptor ribbon synapse. Neuron. 42(4):595-605.

tom Dieck S, Sanmarti-Vila L, Langnaese K, Richter K, Kindler S, Soyke A, Wex H, Smalla KH, Kampf U, Franzer JT, Stumm M, Garner CC, Gundelfinger ED (1998) Bassoon, a novel zinc-finger CAG/glutamine-repeat protein selectively localized at the active zone of presynaptic nerve terminals. J Cell Biol 142:499-509.

Trussell LO. (2002) Transmission at the hair cell synapse. Nat Neurosci. 5(2):85-6.

Uziel A, Gabrion J, Ohresser M, Legrand C (1981) Effects of hypothyroidism on the structural development of the organ of Corti in the rat. Acta Otolaryngol 92:469-480. 
Vincent J, Legrand C, Rabie A, Legrand J (1982) Effects of thyroid hormone on synaptogenesis in the molecular layer of the developing rat cerebellum. J Physiol (Paris) 78:729-738.

von Gersdorff H, Matthews G. (1994) Dynamics of synaptic vesicle fusion and membrane retrieval in synaptic terminals. Nature. 367(6465):735-9.

von Gersdorff H, Vardi E, Matthews G, Sterling P. (1996) Evidence that vesicles on the synaptic ribbon of retinal bipolar neurons can be rapidly released. Neuron. (6):1221-7.

Walsh EJ, McGee J (1988) Rhythmic discharge properties of caudal cochlear nucleus neurons during postnatal development in cats. Hear Res. 36(2-3):233-47.

Walsh EJ, McGee J, McFadden SL, Liberman MC. (1998) Long-term effects of sectioning the olivocochlear bundle in neonatal cats. J Neurosci. 18(10):3859-69.

Warren EH 3rd, Liberman MC. (1989) Effects of contralateral sound on auditorynerve responses. I. Contributions of cochlear efferents. Hear Res. 37(2):89-104.

Weber T, Zimmermann U, Winter H, Mack A, Kopschall I, Rohbock K, Zenner HP, Knipper M (2002) Thyroid hormone is a critical determinant for the regulation of the cochlear motor protein prestin. Proc Natl Acad Sci U S A 99:2901-2906.

Wiederhold ML, Kiang NY (1970) Effects of electric stimulation of the crossed olivocochlear bundle on single auditory-nerve fibers in the cat. J Acoust Soc Am. 48(4):950-65.

Winter IM, Robertson D, Yates GK (1990) Diversity of characteristic frequency rateintensity functions in guinea pig auditory nerve fibres. Hear Res. 45(3):191-202.

Winter H, Braig C, Zimmermann U, Geisler HS, Franzer JT, Weber T, Ley M, Engel J, Knirsch M, Bauer K, Christ S, Walsh EJ, McGee J, Kopschall I, Rohbock K, Knipper M. (2006) Thyroid hormone receptors TRalpha1 and TRbeta differentially regulate gene expression of Kcnq4 and prestin during final differentiation of outer hair cells. J Cell Sci. 119(Pt 14):2975-84.

Xu PX, Adams J, Peters H, Brown MC, Heaney S, Maas R (1999) Eya1-deficient mice lack ears and kidneys and show abnormal apoptosis of organ primordia. Nat Genet 23:113-117.

Yen PM. (2001) Physiological and molecular basis of thyroid hormone action. Physiol Rev. 81(3):1097-142.

Zenisek D, Steyer JA, Almers W. (2000) Transport, capture and exocytosis of single synaptic vesicles at active zones. Nature. 406(6798):849-54. 
Zenisek D, Davila V, Wan L, Almers W. (2003) Imaging calcium entry sites and ribbon structures in two presynaptic cells. J Neurosci. 23(7):2538-48.

Zheng J, Shen W, He DZ, Long KB, Madison LD, Dallos P. (2000) Prestin is the motor protein of cochlear outer hair cells. Nature. 405(6783):149-55. 
I would like to thank Tobias Moser for giving me the opportunity of working in his lab, for his guidance and support throughout my doctoral work and for his scientific and human dedication.

Régis Nouvian always provided invaluable technical help and emotional support. I would like to thank him for generously sharing his vast knowledge and experience and for the essential wit and humour with which he spiced up every single day.

Anna Bulankina and Dietmar Riedel were decisive for the success of these experiments. I would like to thank them for enriching this work with their expertise and criticism.

I would specially like to thank Margitta Köppler for outstanding technical support, in particular for her heroic genotyping efforts, besides her numerous other contributions. She is a pillar of our laboratory.

And to Stefan Röglin, whose tremendous help in breeding these mice brought this project to a happy end.

I would like to thank Tobias Moser, Ralf Schneggenburger, Jakob Soerensen and Detlev Schild for giving away part of their time to evaluate my work and provide good criticism. To all the Inner Ear Lab members, past and present, for creating an excellent working atmosphere. It was really a pleasure to work with such nice people!

I would like to emphatically thank the Lichtenberg Fund of the State of Lower Saxony for its generous support during all these years.

I want to thank the Graduate Program of the International Max Planck Research School, from the administrative members to all my teachers and tutors for their work, for initially trusting my abilities, for giving me the chance of learning a lot and enjoying these years in Germany.

To all my friends in Göttingen and the incredible people I've met elsewhere through this profession: thanks for exploring this path together!!! Hope to see you in the next trip too! To Kamila, for all her love and affection that helped me reach the other shore.

To my family, for raising me with love and encouraging my dreams; they are the silent coauthors of this work. 